\title{
Knowledge integration with customers in collaborative product development project
}

\author{
Mohammad Hossein Eslami
}

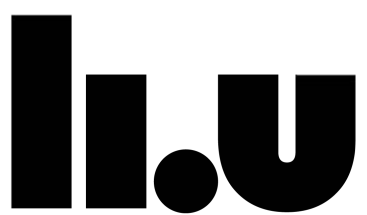

LINKÖPING UNIVERSITY

Department of Management and Engineering Linköping University, Sweden Linköping 2017 
(C)Mohammad Hossein Eslami, 2017

Published article has been reprinted with the permission of the copyright holder.

ISBN: 978-91-7685-609-3

ISSN: 0345-7524

Printed in Sweden by LiU-Tryck, Linköping, Sweden, 2017

Distributed by:

Linköping University

Department of Management and Engineering

SE-581 83 Linköping, Sweden

Tel: +4613281000 


\begin{abstract}
Driven by rapid technological developments, greater customer expectations, and increased product complexity, product development processes increasingly rely on the integration of dispersed specialist knowledge. Consequently, many industrial firms are changing the way they approach product development. Product development increasingly relies on knowledge integration across firm boundaries. Customers are one of the most indispensable sources of knowledge, and their knowledge needs to be integrated during product development. However, little is known about the processes and mechanisms used to integrate customer knowledge in product development. Therefore, firms must devise processes and mechanisms that support knowledge integration with customers. This thesis aims to investigate knowledge integration with customers in collaborative product development.
\end{abstract}

The work described in this thesis combines a case study with a survey approach. More specifically, five case studies were conducted at three industrial manufacturing firms. Data were collected in 46 interviews, along with informal discussions, workshops, and secondary material. The case studies revealed the role of knowledge integration, knowledge integration mechanisms, and the importance of contextual factors related to the customer's technical capability, and the locus of initiative for the product development project. A cross-sectional survey was performed in order to ascertain the role of knowledge integration and its effect on innovation performance and the effect of firms and customers' technical capability and locus of initiative on knowledge integration with customers. The survey study generated 216 responses from firms operating in the Swedish manufacturing industry.

This thesis consists of a compiled summary and five appended papers. The results in these provide the basis for modelling knowledge integration with customers. The findings confirm that integrating knowledge with customers in product development is associated with better innovation performance. Further, the results point to the dynamic characteristics of knowledge integration in product development processes. More specifically, firms tend to apply different combinations of mechanisms in different phases, depending on the intended content of the knowledge contribution of the customer and the requirements of each phase in the development process. In addition, the degree of technical capability, internal integration capability, and locus of initiative are important factors influencing knowledge integration processes. This thesis sheds new light on collaborative product development with customers by demonstrating that knowledge, and particularly the integration of knowledge across firm boundaries, is a central property of product development. The study focuses on industrial and manufacturing firms, complementing current perspectives on the role of customers in other sectors. In this particular sector, complexity and system-wide implications need to be resolved together with customers through knowledge integration activities. An important implication of the thesis is that firms need to devise mechanisms for knowledge integration with customers, and be prepared to redevise these as the firm progresses through the product development phases.

Keywords: Product development, knowledge integration, customer collaboration, technical capability, locus of initiative, internal integration. 


\section{Sammanfattning}

Produktutveckling har blivit allt viktigare på grund av teknologisk utveckling, större kundförväntningar och en ökad produktkomplexitet. Produktutvecklingsprocesser kräver därför alltmer integration av distribuerad specialistkunskap. Som ett resultat av detta, inför många tillverkningsföretag nya arbetssätt för produktutveckling. Produktutveckling sker i allt högre grad genom aktiviteter som hjälper företag att integrera kunskap över företagsgränsen. Företagens befintliga eller framtida kunder är en av de mest viktiga kunskapskällor i produktutveckling, men det finns relativt få studier som undersöker processer och mekanismer för kunskapsintegration med kunder. Syftet med denna avhandling är att undersöka kunskapsintegration med kunder i produktutvecklingssamarbete.

Forskningen bygger på flera fallstudier och en enkätundersökning som bygger på 216 svar från svenska tillverkningsföretag. Fem fallstudier har genomförts på tre stora tillverkningsföretag. Fallstudierna bygger på totalt 46 intervjuer, informella diskussioner med företagens anställda, workshops, och sekundär data. Fallstudierna ger en insikt i vikten av kunskapsintegration i produktutveckling, integrationsmekanismer och kontextuella faktorer som påverkar kunskapsintegration. Fallstudiernas resultat har sedan undersökts vidare genom en enkätstudie. Enkätstudien bekräftar att kunskapsintegration har en signifikant betydelse för innovationssamarbete med kunder, och att kundens tekniska förmåga samt initiativtagande i produktutveckling påverkar innovation positivt.

Avhandlingen bygger på en kappa och fem artiklar. Artiklarnas sammansatta resultat och syntesen i kappan visar hur företag integrerar kunskap med kunder i produktutveckling genom att använda konventionella produktutvecklingsprocesser, gemensam problemformulering och problemlösning. Resultaten bekräftar att kunskapsintegration med kunder leder till bättre produktutvecklingsresultat. Företag använder dessutom olika kombinationer av mekanismer i olika skeden av produktutvecklingsprocessen. Resultaten visar vidare att mekanismerna förändras under produktutvecklingsprocessens gång, för att svara mot de olika utmaningarna $\mathrm{i}$ varje fas, och en förväntning av det kunskapsbidrag som kunden kan tänkas ha. Resultaten tyder dessutom på att kundens tekniska förmåga, initiativ i produktutvecklingsprocessen och den interna integrationsförmågan är viktiga faktorer som påverkar kunskapsintegration.

Avhandlingen bidrar till förståelsen för kundsamarbete i produktutveckling, genom att betona vikten av kunskapsintegration över företagens gränser. Resultaten visar att företag behöver utveckla effektiva processer för kunskapsintegration, för att kunna hantera en ökad grad av komplexitet. Avhandlingen bygger på studier av kundsamarbete i industriella sammanhang och kompletterar befintliga studier som fokuserar på, hur till exempel slutanvändare kan integreras i produktutveckling. Produktutveckling i industriella sammanhang karakteriseras ofta av ett behov att hantera en hög produktkomplexitet och systemaspekter, något som ställer annorlunda krav på kunskapsintegration med kunder. Industriella företag behöver därför utveckla mekanismer för kunskapsintegration med kunder. Dessa ska vara flexibla och kunna justeras enligt behoven och förutsättningarna i produktutvecklingsprocessen. 


\section{Acknowledgements}

More than five years ago, when I decided to start my PhD studies, I could not imagine what an adventure this undertaking would be. Looking back at this journey, I can see that some of the tasks were very tough and overwhelming. Still, the overall experience was truly enjoyable, especially the opportunities to collaborate with different individuals, whose input helped me to come to this point. I can honestly say that these were the most intense years in my life, but were also the most satisfying, as I was fortunate to meet and work with so many great and enthusiastic people, whom I would like to thank for their support and contribution to this thesis.

First and foremost, I would like to thank my supervisor. Nicolette Lakemond, I will always remain indebted to you for your support and valuable feedback, your willingness to respond to my questions and inquiries so promptly (even during weekends), for co-authoring different papers with me, for encouraging me during my learning process, and finally for trusting by ability to write a new research application.

I am also grateful for my secondary supervisors. Christian Berggren, thank you for your valuable comments, which were instrumental in shaping this thesis, but also for your advice throughout the research process. Stefano Brusoni, thank you for contributing to my work with new perspectives and for co-authoring a paper with me.

I also wish to thank Mats Magnusson for his comments on the early draft of this thesis and for providing many insightful suggestions.

Furthermore, I would also like to thank Alberto, Benny, Carina, Dag, Filiz, Ingrid, Ksenia, Lotta and all my great colleagues at PIE for creating a good and inspirational working environment, which was an additional motivation for me to come to work every day.

To my friends, thank you for your understanding and encouragement in many difficult situations. This achievement would have not been possible without it! While I cannot mention you all by name here, you know that you bring joy into my life and are always on my mind.

My most sincere gratitude goes to my mother and father for helping me to realize my own potential. Thank you for your endless love and support, which is the greatest gift anyone has ever given me! I love you.

Mohammad Hossein Eslami

Linköping, 2017 
To my mother and my father 


\section{Additional papers}

Eslami, M. H., and Lakemond, N. (2016). Knowledge integration with customers in collaborative product development projects. Published in the Journal of Business \& Industrial Marketing, 31(7), 889-900.

Eslami, M. H., Lakemond., and Brusoni, S. (2016). Knowledge integration in complex systems development: what suppliers actually do to integrate knowledge with customers?. Earlier version of the paper presented at the IPDM conference, Paris, 2013. Submitted to a scientific journal, received major revision in November 2016.

Eslami, M. H., and Lakemond, N. (2016). Internal integration in complex collaborative product development projects. Published in the International Journal of Innovation Management, 20(01), 1650008.

Eslami, M. H., and Lakemond, N. (2016). Knowledge integration with customers in product development processes: Empirical evidence from Swedish manufacturing firms. Earlier version presented at the CINet conference, Stockholm, 2015. Working paper to be submitted to a scientific journal.

Eslami, M. H., and Lakemond, N. (2016). The role of technical capability and locus of initiative on knowledge integration with customers in collaborative product development., Accepted in the IMP conference, Poznan, 2016. Working paper to be submitted to a scientific journal. 


\section{Related publications}

Eslami, M. H., and Oinonen, M. (2015). Knowledge integration between customers and suppliers during solution development process. Earlier version presented at ISPIM conference, Budapest, 2015, Working paper to be submitted to a scientific journal.

Eslami, M. H., Rosell, D.T., and Melander, L. (2016). Kunder och leverantörer i öppna respective slutna innovationssamarbeten. Öppen innovation: i teori och praktik, Studentlitteratur, 2016, 203-220.

Eslami, M. H., and Melander, L. (2016). Organizational challenges when collaborating in product innovation projects. Presented at CINet conference, Turin, 2016. 


\section{Table of contents}

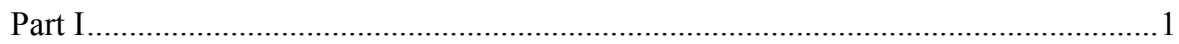

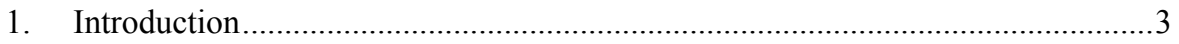

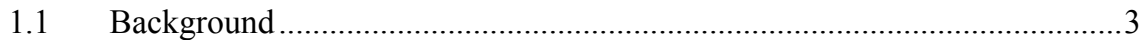

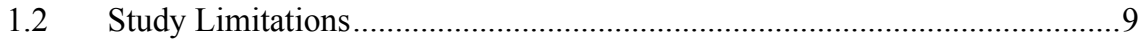

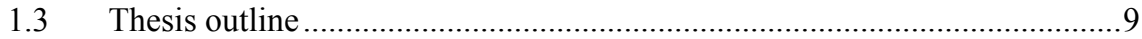

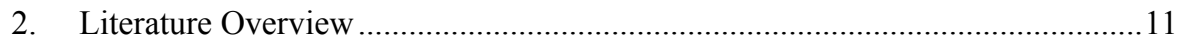

2.1 Customer collaboration and customer contribution ......................................11

2.2 Customer collaboration: a literature review..................................................13

2.3 Collaborative product development with customers based on the

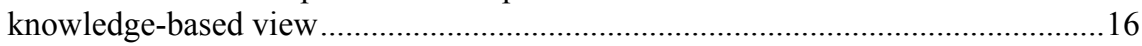

2.3.1 Knowledge-based view and knowledge integration .............................17

2.3.2 Challenges of knowledge integration in collaborative product

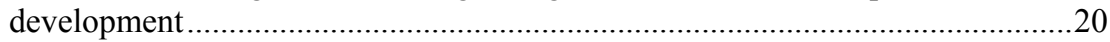

2.3.3 Knowledge integration mechanisms ....................................................22

2.4 Customer collaboration in product development processes...........................23

2.4.1 When should a firm collaborate with customers? ................................24

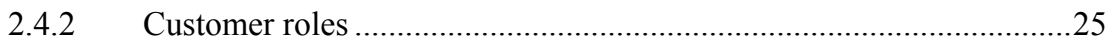

$2.5 \quad$ Factors related to customer collaboration in product development ...............27

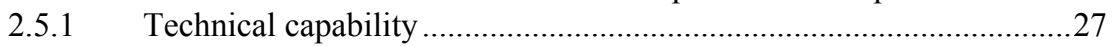

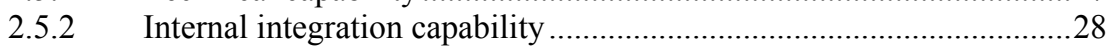

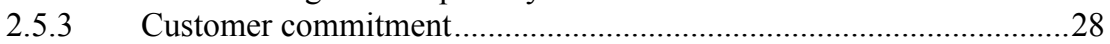

2.6 Summary of the literature …………………………………………......29

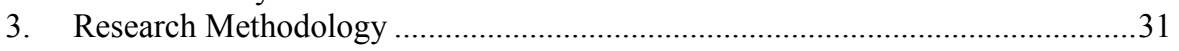

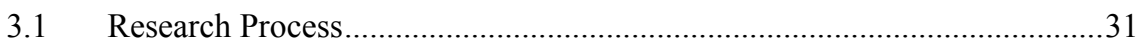

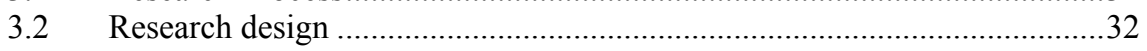

3.3 Defining the focus of the study and the literature review..............................33

$3.4 \quad$ Case study approach …………………………………………………........

3.4.1 Firm selection for case study …………………............................... 35

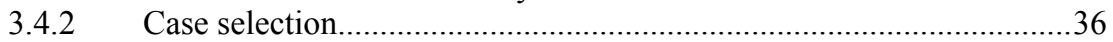

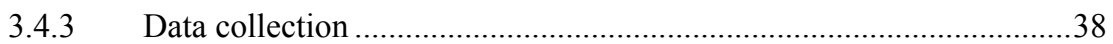

3.4.4 Case study data analysis........................................................................

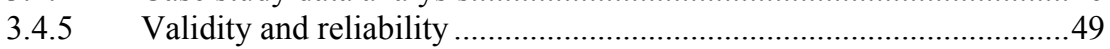

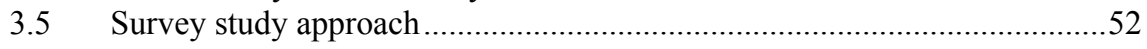

3.5.1 Sample selection and data collection ..................................................53

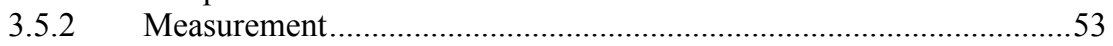

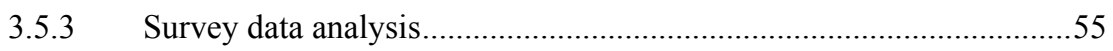

3.6 Presenting the material in papers and authorship .........................................55

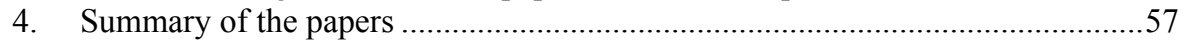

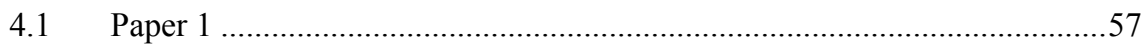

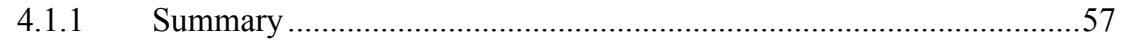

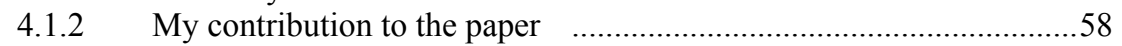

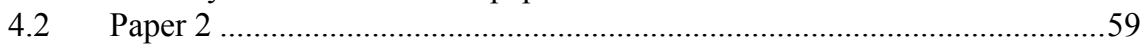

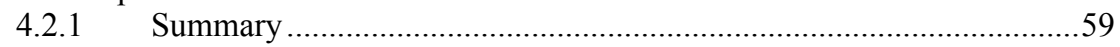

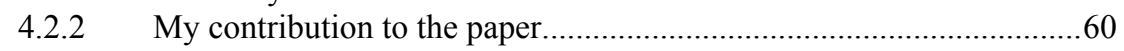

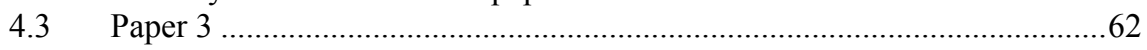

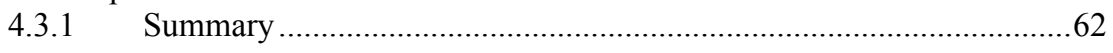




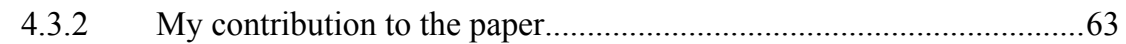

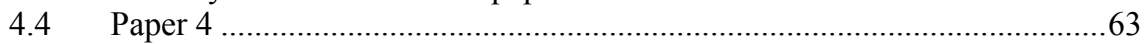

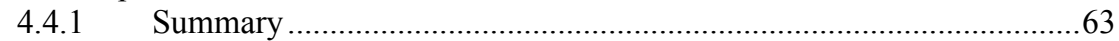

4.4.2 My contribution to the paper...............................................................64

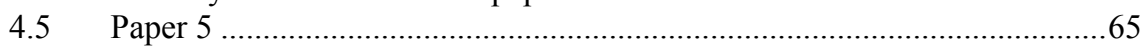

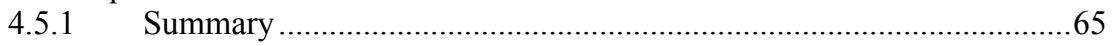

4.5.2 My contribution to the paper.................................................................65

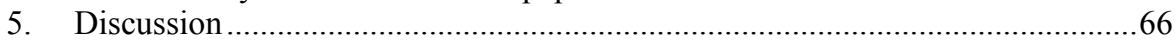

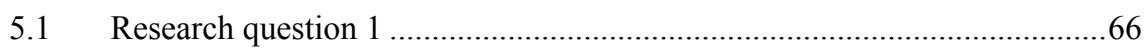

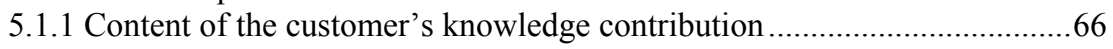

5.1.2 Knowledge integration mechanisms with customers...................................68

$5.2 \quad$ Research question 2 ……………………………………………......

5.2.1 Internal integration capability ...............................................................

5.2.2 Technical capability ............................................................................

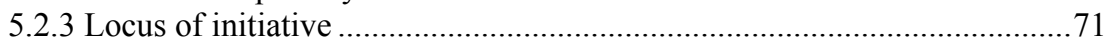

5.2.4 Relationship between technical capability and locus of initiative...............72

$5.3 \quad$ Research question 3 ………………………………………………....

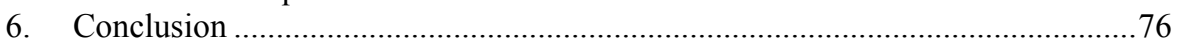

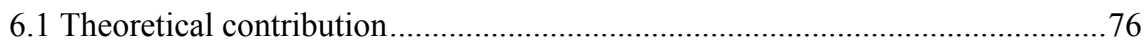

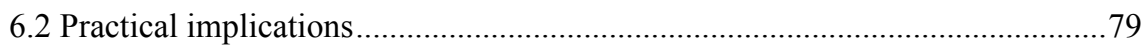

6.3 Limitations and further research .................................................................. 80

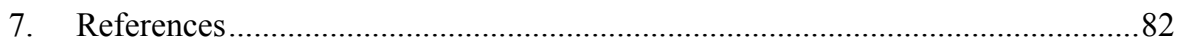

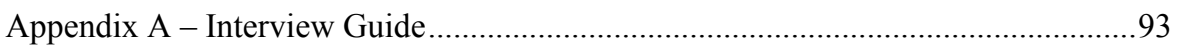

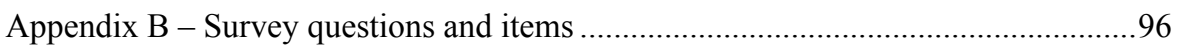

Part II 


\section{Part I}

\section{Compiled Summary}




\section{Introduction}

This chapter commences by providing the background of this study in order to elucidate the process of knowledge integration between firms and their customers in collaborative product development. First, the importance of studying customer collaboration as a phenomenon is delineated, and some gaps in the literature are discussed. Second, the specific focus on knowledge integration in this thesis is explained and related to collaborative product development. Third, the purpose and the research questions are described. Fourth, the study's limitations are discussed. Finally, the outline of the thesis is presented.

\subsection{Background}

One of the most important goals of product development is to create a product that provides value to the customer. Therefore, customers have long been considered important in the product development literature. It is widely acknowledged that collaboration with customers is one of the key factors in determining the success of product development (e.g., Gruner and Homburg, 2000). Previous studies have identified customers as key collaboration partners of firms (Un et al., 2010; Laursen and Salter, 2006; Lakemond et al., 2016). Not only is this confirmed in research studies, but many industrial firms, including Atlas Copco, ABB, and SKF, acknowledge that customers are key to their product development processes. One of development managers of SKF, the Swedish manufacturer of bearings and units, seals, mechatronics, services, and lubrication systems, describes the increasing importance of customer collaboration for product development as follows:

Due to increasing dynamic markets and technologies, which result in evolving customer needs, the focus of our firm continually changes during the course of a product development project. In most cases, our knowledge of their needs is insufficient; thus, we need to involve them (i.e. the customer) into new product development. In fact, understanding our customer is the key element in our efforts to enhance the value of our innovation, which increasingly necessitates that customers are involved in the entire product development process. Therefore, we believe that we must align our key innovation activities with capable customers to minimize the risk of failure.

In addition, many other firms experience a similar situation of more dynamic markets and faster technology development, and acknowledge the importance of customer collaboration for successful product development. Consequently, it seems that firms are increasingly collaborating with their customers to develop new products.

Managing innovation and product development processes presents firms with inevitable challenges. The importance of customer collaboration is underlined by the 
fact that in industries that are subject to rapid changes and innovation, nearly two-thirds of innovative products fail as a result of inadequate responses to customer demands (Lempres, 2003). Customers increasingly demand that new products have advanced functionality, which requires a number of different technologies to be integrated. The knowledge of these technologies can be widely dispersed across different firms. Thus, firms cannot rely only on their own internal knowledge base (von Hippel and Katz, 2002) and internal efforts to predict customer needs and expectations ( $\mathrm{Xu}$ and Walton, 2005). Instead, they need to develop strategies to tap into the knowledge of their customers and integrate this knowledge into their product development processes. In other words, firms must look for ways to capture the knowledge contributions of their customers and ask their customers for assistance in developing innovative products and bring them to the market on time (Chesbrough, 2006).

Several researchers argue that customers can be more knowledgeable about the product characteristics than are the developing engineers (e.g., Blazevic and Lievens, 2008; Nambisan, 2002). In fact, customers' ideas and expectations pertaining to new solutions might introduce unfamiliar perspectives into product development, which can lead to a higher degree of creativity (Maltz et al., 2001). Therefore, rather than considering customers as passive actors, firms must view them as providers of important knowledge. In many cases, they are considered as central actors in product development processes.

The focus on customers and their importance for product development is not new. Previous research on customers in relation to product development has mostly focused on understanding customers' needs and requirements better. Several approaches have been developed that can help firms to capture the customers' demands, including working with lead users (von Hippel, 1976), utilizing quality function deployment (Akao, 1990), developing a market orientation (Christensen and Bower, 1996), making sure that the voice of the customer is heard (Griffin and Hauser, 1993), implementing customer-driven innovation (Billington, 1998), and using customers as co-developers (Jeppesen and Molin, 2003). The lead user concept, which was proposed by von Hippel (1976) and developed by other researchers (Kolter, 1999; Lilien et al., 2002; Ulwick, 2002; von Hippel and Katz, 2002), has become a well-established approach to product development based on systematic recognition of innovative customers for knowledge integration. In this approach, the specific needs of innovative customers can help firms to develop new ideas for product development. In contrast to the lead-user approach, other approaches such as Quality Function Deployment (Akao, 1990) implicitly assume that firms already have innovative ideas, which can be developed with customer insights (Huovila and Seren, 1998).

Existing approaches to customer collaboration have a common feature in that they tend to focus on the initial stages of the product development process (von Hippel, 1976 Griffin and Hauser, 1993; Billington, 1998; Thomke and Fujimoto, 2000; Paustian, 2001; Dahan and Hauser, 2002). Customers can have the greatest influence in these 
stages (e.g., Kim and Wilemon, 2002). In the early stages, it is important to define the customers' needs and expectations quite precisely and build the business case based on this. However, capturing these customer demands in the early stages might not be enough. Rather, what is required is a deep understanding based on a collaborative relationship with customers focused on the development and implementation of new solutions. The customer's contribution often needs to extend beyond ideas and requirements, especially in the context of business-to-business relationships and the development of complex products that need to be integrated with customers' products and systems.

In relation to the above, the present study refers to collaborative product development with customers as a type of arrangement that enables firms and customers to jointly acquire and utilize disparate knowledge (Homburg and Kuehnl, 2014). The main goal of these arrangements is related to value creation (Emden et al., 2006). In order to achieve this, a relatively high level of transparency and synergies in participant actions is necessary. Consequently, traditional ways to capture customer inputs may no longer be enough. Rather, firms need to collaborate with their customers to a larger extent, preferably over an extended time frame throughout the product development processes. However, existing studies have not extensively addressed collaborative product development with customers and the aspect of jointly acquiring and using knowledge residing at multiple firms (Veryzer and Borja de Mozota, 2005; Morrison et al., 2004). Firms that need to collaborate with their customers in product development face some specific challenges. There are, for example, issues related to when, how, how much, and for how long the collaboration needs to go on. More specifically, challenges arise due to increased dependency, timing, the focus of the contribution, and the intensity of the collaboration (Nambisan, 2002), potential lack of commitment (Lagrosen, 2005), and sometimes limited customer capability to provide relevant knowledge (Athaide and Klink, 2009). New approaches to overcome these challenges need to be formulated to derive the benefits from customer collaboration (Lilien et al., 2002).

As collaborative product development with customers is based on the use of knowledge from both firms, the above challenges can be better understood by applying a knowledge-based perspective (KBV) of firms. KBV identifies knowledge as the most important resource that firms use to create competitive advantage (Grant, 1996). However, as knowledge is usually dispersed and resides with individuals, the main challenge related to creating competitive advantage is related to the integration of this dispersed knowledge. This has consequences for organizing intra- as well as inter-firm relationships (Dyer and Singh, 1998). In the context of strategic alliances, Grant and Baden-Fuller (2004) have argued the advantages of accessing complementary knowledge residing at other firms. The challenges related to collaborative product development with customers can also be considered from a KBV perspective. Therefore, understanding knowledge integration is crucial to the study of effective collaborative product development with customers. 
Until now, little attention has been paid to knowledge integration with customers in product development. Although the knowledge of customers has been proposed as key, few studies specifically focus on how this knowledge can be integrated, what are the key issues when integrating knowledge with customers, and how knowledge integration with customers occurs and evolves in different stages in the product development process. In order to address this gap and arrive at a deeper understanding of collaborative product development with customers, this study aims to contribute new insights into knowledge integration with customers in collaborative product development. Accordingly, the purpose of this study is formulated as follows:

The purpose of this study is to investigate knowledge integration with customers in collaborative product development.

The present study aims to fill the gap in pervious knowledge by investigating collaborative product development with customers to gain new insights into how customer knowledge can be integrated. This involves devising appropriate knowledge integration mechanisms in order to manage customer knowledge in collaborative product development. These mechanisms can help to integrate different but complementary knowledge bases. In addition, Tell (2011) argues, in the context of knowledge integration in innovation in general, that there is a lack of insight into not only the mechanisms but also the dynamics of knowledge integration and the use of the related mechanisms. This can be translated into the context of collaborative product development with customers, where De Boer et al. (1999) also has posited that firms need to select proper mechanisms for integrating customer knowledge during the collaborative product development process. Several researchers have proposed a number of different knowledge integration mechanisms (Grant, 1996; Schmickl and Kieser, 2008). For example, Grant (1996) has identified directives, routines, sequencing, and group problem solving as particularly useful in this context. These mechanisms could be analyzed according to contingency factors, as each of these might be more or less relevant under different circumstances. Different phases and conditions of the development process may present different challenges. This may point to the need to devise knowledge integration mechanisms that can be adjusted over time according to the specific requirements at that time. Perhaps, knowledge integration approaches need to rely on combinations of knowledge integration mechanisms. Consequently, it seems important to understand how knowledge integration mechanisms are used and to make changes as needed during collaborative product development processes (cf. Okhuysen and Bechky, 2009). This issue is addressed by the first research question that guides the present study.

RQ1: How do firms integrate customer knowledge in collaborative product development processes? 
The second aspect of this study pertains to identifying the situational factors that affect the appropriateness of knowledge integration mechanisms to customers in the collaborative product development processes. In some situations, knowledge integration may be desirable, but can be difficult to achieve in certain circumstances. For example, even when customers are inclined to contribute to development activities, they may lack the pertinent skills and knowledge (Peled and Dvir, 2012). Thus, it is challenging for firms to understand when and in what situations they can benefit most from knowledge integration with customers. Previous studies have discussed a wide range of factors that can have effects on customer collaboration in product development, such as lack of partner commitment (e.g., Krause et al., 2007), lack of internal integration (e.g., Mishra and Shah, 2009), and customer ability (e.g., Wagner, 2010). However, these studies have not specifically considered these factors from the perspective of knowledge integration. In case a relationship does exist, it is necessary to ascertain how these contingencies can affect customer knowledge contribution. Therefore, the second research question of this thesis is expressed as follows:

RQ2. What situational factors affect customer knowledge integration in collaborative product development processes?

The third aspect of this research relates to the impact of knowledge integration with customers on innovation performance. Empirical studies exploring customer collaboration have demonstrated that integrating customer's knowledge into product development helps reduce innovation risks, while resulting in a higher degree of product innovativeness (Kohli and Jaworski, 1990; Griffin and Hauser, 1993; Yi-Renko et al., 2001; Hauser et al., 2006). It has been argued that integrating knowledge provided by customers can expedite the learning processes and increase the number of successful products generated by the manufacturing firms. As noted by Littler et al. (1995), collaboration with customers provides many opportunities and expands the firm's knowledge, but is also subject to certain risks, such as less control over product development. In practice, knowledge integration with customers is carried out under the implicit expectation of positive effects, such as spillover of knowledge from customers to the manufacturing firms. However, if manufacturing firms are highly reliant on the knowledge input of customers, they would face some risk, such as developing products that are overly specific or based on incorrect or biased information (Enkel et al., 2005). Given the risks associated with customer collaboration, some researchers and practitioners question whether the customer's knowledge should be integrated collaborative product development processes at all. In addition, very little is presently known about the effectiveness of the processes utilized for knowledge integration with customers and their impact on innovation (e.g., Yi-Renko et al., 2001). Following the knowledge-based perspective, which considers knowledge as a critical 
resource, it can be posited that customers provide important knowledge that contributes to, and is indispensable for, collaborative product development processes. Thus, integration of knowledge becomes a key factor. By investigating the effects of collaborative product development with customers from a knowledge integration perspective, this study responds to the call for more extensive investigation into the effects of acquiring and utilizing knowledge, through knowledge integration, on innovation performance. Thus, the third research question is formulated as follows:

\section{RQ3: How does knowledge integration with customers affect innovation performance?}

In light of the above, this study provides an understanding of how knowledge integration with customers evolves through the stages of the product development process while meeting the demands for effective and efficient coordination and swift progress. This involves identifying different types of knowledge that customers and firms need to integrate. It also includes a focus on what mechanisms are used for specific types of knowledge in different stages of the development process. In addition, the study presents an examination of different factors and their effects on knowledge integration with customers in the stages of the product development process.

The above research questions are answered by adopting two different approaches. First, a case study of three Swedish innovative firms that are market leaders in their industry was conducted. At these firms, five collaborative product development projects were studied. This was followed by a cross-sectional survey of Swedish manufacturing firms employing more than 50 staff. Sweden was chosen as a study context as, in the global innovation index of 2015, it ranked third among the most-innovative economies and seventh in terms of creative output (Florida et al., 2015).

This research differentiates product development from service and process development (Pisano, 1994; Meyer and DeTore, 1999). Product development refers to the introduction of a new product and improvement in the functionality of an existing product, which are seen as innovative activities (Edquist et al., 2001). In this context, firms pursue product development projects to introduce changes in their business concept (Wolpert, 2002). Thus, in this work, the term "product development process" pertains to innovative product design and development. Typically, this process comprises several project stages (concept, development and testing, etc.) in which different product development activities are undertaken.

The current study specifically focuses primarily on firms' relationships with their customers in a business-to-business context, whereby firms (including manufacturing supplier firms) play the role of developers of a new system or product. The term "customer," rather than implying end user, refers to another product-developing company that uses the developed product or system in proprietary operations. Research 
in the field of customer collaboration in product development uses a variety of terms to refer to customer collaboration. These include customer involvement, customer cooperation, customer contribution, and coordination. However, the present study uses the terms collaboration and contribution to refer to the arrangement and relationship between two firms (customer collaboration) and the input from one of these firms, i.e., the customer (customer contribution). These concepts will be discussed further in Section 2.1 of this thesis.

\subsection{Study Limitations}

The analyses conducted in this study pertain to the concept, development, and testing phases in accordance with the idea of the stage-gate system (Cooper, 2008; Cooper and Edgett, 2012). Consequently, collaboration with customers during product commercialization and installation scanning is beyond the scope of this research. This limited scope is justified by the fact that, in a business-to-business context, the process usually comprises these three phases (concept, development, and testing), in which information is gathered and knowledge can be integrated by different functions within organizations.

Moreover, the study does not include collaboration with consumers and end users. There should be a potential for knowledge integration with consumers and end users in product development processes, especially in the commercialization phase, but this study focuses on business-to-business contexts.

In addition, this study is limited to product development; hence, other contexts such as new service or solution development are not explored, even though they too can benefit from customer contribution. Moreover, although firms can integrate knowledge with other external stakeholders, such as universities and competitors, these relationships were not examined in the present study.

The case studies discussed in this work pertain to large technical and highly capable manufacturing firms that mostly develop complex products, thus excluding other firm structures, such small business enterprises. In addition, all firms that took part in the survey employed at least 50 staff and had a designated research and development unit. Consequently, in line with the case studies, the survey did not extend to other firm types.

\subsection{Thesis outline}

The first part of this thesis provides a summary of the five appended papers, referred to as "Kappa." Chapter one of Kappa first provides the background of the study and then presents its purpose and the research questions. Chapter two describes the theoretical framework employed to explore customer collaboration in product development. This 
is followed by a review of the knowledge integration literature and existing studies focusing on customer collaboration. Chapter three defines the methodology and describes the case study and survey study approaches. Chapter four provides an overview of the appended papers, and Chapter five discusses the study results. Finally, Chapter six concludes the first part by discussing the study's essential contributions to the theory and practice of knowledge integration with customers in collaborative product development.

The second part of this thesis is devoted to the discussion of the five papers. Paper 1 focuses on the role of customers and their knowledge contribution to product development. Paper 2 discusses the mechanisms of knowledge integration with customers, while Paper 3 studies the internal integration of knowledge provided by customers and firms. The effect of customer knowledge integration on innovation performance is the topic of Paper 4, and Paper 5 studies the factors that can influence knowledge integration with customers. 


\section{Literature Overview}

This chapter presents an overview of the theoretical background and the literature relevant to this study. First, it discusses and defines two main concepts: customer collaboration and contribution. Thereafter, it provides a brief overview of the literature on customer collaboration in product development. The aim is to give the previous research perspective on the importance of customer collaboration and the approaches that have been employed thus far in customer collaboration research. Further, the theoretical perspective of this thesis, related to the knowledge-based view, is outlined with a specific focus on the importance, challenges, and mechanisms of knowledge integration. This is followed by a discussion on the possible approaches to collaborative product development projects, including the timing of customer collaboration, the different roles that customers can adopt, and the factors that affect customer collaboration. The chapter ends with a brief summary of the key findings reported in the existing literature and the background of this thesis.

\subsection{Customer collaboration and customer contribution}

In the mid-1980s, firms started to realize that being technology driven (i.e., first creating new technology and then trying to identify suitable applications and markets) is not the optimal approach to innovation management (Ulwick, 2002). Consequently, they shifted from a technology-pull to a market-push perspective. This has prompted the development of a customer-driven approach to innovation, whereby firms commence each innovation project by identifying customer needs, which they use as the input into their development processes. Such a strategy helps in aligning internal resources to market needs. To achieve this alignment and attain sufficient knowledge of customer needs, firms started to incorporate their key customers into product development initiatives (Callahan and Lasry, 2004; Hauser et al., 2006; Greer and Lei, 2012). While the extent and scope of customer collaboration has considerably expanded since then (Alam and Perry, 2002; Fang, 2008; Öberg, 2010), little is known about the best timing of customer contribution and the best means of obtaining it (Kaulio, 1998; Lagrosen, 2005).

This gap in the extant knowledge was addressed in the present study, where customer collaboration refers to the joint efforts of the firm and its key customers aimed at achieving a successful product development outcome (Emden et al., 2006). This study focuses specifically on customer collaboration where firms acquire resources and skills that they cannot develop internally. Thus, they need to obtain complementary knowledge of their customers. Previous research in the field of customer collaboration indicates that collaboration with customers in product development allows firms to interpret market trends more effectively, as well as successfully incorporate them in their product development (e.g., von Hippel, 1986; Lilien et al., 2002; Lin et al., 2010; Lau, 2011). Empirical evidence also shows that collaboration with customers could be 
an effective response to the demand for customized products, which necessitates collaboration with customers in order to identify the key product features and thus reduce development risks.

We need to understand not just the importance of customer collaboration and the different approaches to it but also what customers actually contribute, how these contributions are best integrated into product development processes, and what benefits can be derived from these collaborations. In the context of the present study, customer contribution refers to the specific customer knowledge and expertise integrated in the different phases of the product development process. The benefits of customer contribution in product development have been highlighted in research on innovation management. For instance, Sethi (2000) observed that increased input from customers during the early phases of collaborative product development can result in a better understanding of customer needs and requirements. This, in turn, helps reduce the risk of pursuing a product design that would provide poor functionality in the later phases of the development process, while allowing the company to generate new ideas and solutions that can increase innovativeness (Tsai, 2001; von Hippel, 1988). However, some previous studies have also shown that customer contribution in the form of feedback and suggestions, in the development phase, can provide an understanding of customer expectations, which can be a valuable resource that can lead to competitive advantage (Blazevic and Lievens, 2008). In addition, Nambisan (2002) stated that customer contributions during the later phases of product development can also be beneficial, as testing product performance in a variety of user contexts can allow manufacturing firms to refine prototypes, focusing on specific factors, such as efficiency and safety (Lagrosen, 2005).

While benefits of customer collaboration and contributions seem to be numerous, scholars have argued that customer collaboration does not necessarily guarantee success (Gatignon and Xuereb, 1997; Lilien et al., 2002, Callahan and Lasry, 2004; Brockhoff, 2003). The reasons for this can be two-fold. First, existing customers will not always recognize the value of new products with distinct performance attributes that disrupt existing markets (Christensen, 1997). Therefore, collaborating with existing customers will not always be fruitful when firms aim at innovations that are radical and disruptive in character. Although we acknowledge this, the present thesis focuses on product development activities that are not necessarily disruptive in character, but rather aim to address the future needs of existing customers. Second, there seem to be risks related to customer collaboration that result from the effort, time, and related costs of collaboration (e.g., Lilien et al., 2002). This assertion is highly relevant in this thesis as it indicates a need for further investigation of effective and efficient approaches to capture customer contributions in such a way that the benefits outweigh the costs. The next section provides an overview of previous research addressing customer collaboration. This will further specify the gaps in the current knowledge of the topic. 


\subsection{Customer collaboration: a literature review}

The existing literature on customer collaboration in product development dates back to the 1980s, when von Hippel published one of his seminal works on the sources of innovation and proposed the lead user approach (von Hippel, 1976; 1986; 1988). This approach encourages firms to collaborate with some of their main customers. The lead user approach was subsequently studied by numerous researchers and practitioners, who concurred that the lead user role should be assigned to customers capable of identifying future market trends (von Hippel, 1986; Lilien et al., 2002; Ulwick, 2002; von Hippel and Katz, 2002). The developments in Japanese industry and an increasing focus on market-driven product development triggered further initiatives in customer collaboration, such as quality function deployment (Akao, 1990), user toolkits (Seybold, 2001), and conjoint analysis (Gustafson et al., 2000). These methods, which gained increasing attention during the 1990s and 2000s, aim to provide tools to assist firms in gathering a broad spectrum of customer needs by asking customers directly and indirectly about their expectations of the new product.

While most of the studies conducted in this period focused on the tools or methods that can be adopted to ensure that collaboration with customers is beneficial to the firm, several authors approached customer collaboration as a more multifaceted phenomenon that is influenced by many factors (Luthje and Herstatt, 2004; Lettl, 2007; Wagner, 2010). For instance, Wagner (2010) examined new product development efforts of 227 manufacturing firms and indicated that the benefits of collaborating with the customer to develop a product are positively associated with the firm's capability, whereas customer collaboration becomes less relevant for less-capable firms. Other researchers posited that reciprocal commitment of resources and trust will also enable a high degree of customer contribution, as this assists the firm to remain competitive in the market (Ritter and Walter, 2003; Muthusamy et al., 2008). In addition to the situational factors that can affect customer collaboration, studies also prompted new streams of customer collaboration research by investigating the customer's roles (e.g., Fang et al., 2008) and motives (Brockhoff, 2003), as well as the importance of relationship development and adaptation (e.g., Ritter and Walter, 2003).

In addition, the research focus shifted to the effects of customer collaboration in product development. As mentioned in the preceding section, these studies revealed that allowing customers to actively contribute to the development of new products resulted in a higher degree of product innovativeness, while reducing innovation risk (Enkel et al., 2005; Tsai, 2001; Lau, 2011). However, mixed results are found; according to a recent study by Chang and Taylor (2016), for example, customer contribution to product development might hamper the performance of the new product. These and other authors are of the view that, owing to the complex relationship between customer collaboration and product development performance, success is not always guaranteed, as it is influenced by a multitude of factors that must be further explored. In other words, firms not only need to adopt suitable approaches for customer collaboration but must 
also consider the timing and the scope of the input the customer provides at each stage of the collaborative product development process. A summary of the reviewed literature on customer collaboration in product development in this thesis is presented in Table 1 .

Table 1. Summary of the customer collaboration literature review

\begin{tabular}{|c|c|c|c|c|}
\hline Categories & Study & Method & Context & Contribution \\
\hline \multirow{5}{*}{$\begin{array}{l}\text { Customer } \\
\text { approach }\end{array}$} & $\begin{array}{l}\text { von Hippel } \\
\text { (1986) }\end{array}$ & Conceptual & $\begin{array}{l}\text { Product, } \\
\text { service, and } \\
\text { process }\end{array}$ & $\begin{array}{l}\text { Proposed the lead user approach and } \\
\text { recommended that firms innovate by } \\
\text { collaborating with customers whose } \\
\text { needs are believed to reflect market } \\
\text { requirements in the future. }\end{array}$ \\
\hline & $\begin{array}{l}\text { Akao } \\
\text { (1990) }\end{array}$ & Conceptual & $\begin{array}{l}\text { Product } \\
\text { development }\end{array}$ & $\begin{array}{l}\text { Defined quality function deployment } \\
\text { approach, aimed at capturing } \\
\text { customer requirements in product } \\
\text { design. }\end{array}$ \\
\hline & $\begin{array}{l}\text { Kaulio } \\
\text { (1998) }\end{array}$ & Conceptual & $\begin{array}{l}\text { Product } \\
\text { development }\end{array}$ & $\begin{array}{l}\text { Defined different methods of } \\
\text { customer collaboration that can be } \\
\text { adopted during the specification, } \\
\text { concept development, and prototyping } \\
\text { phases. }\end{array}$ \\
\hline & $\begin{array}{l}\text { Luthje and } \\
\text { Herstatt } \\
(2004)\end{array}$ & Conceptual & $\begin{array}{l}\text { Process and } \\
\text { product } \\
\text { development }\end{array}$ & $\begin{array}{l}\text { Discussed the lead user approach, } \\
\text { embedded in theories and empirical } \\
\text { findings, in the innovation process and } \\
\text { identified four specific steps. }\end{array}$ \\
\hline & $\begin{array}{l}\text { Maltz et al. } \\
(2001)\end{array}$ & $\begin{array}{l}\text { Survey of } 256 \\
\text { high } \\
\text { technology } \\
\text { firms }\end{array}$ & $\begin{array}{l}\text { Product } \\
\text { development }\end{array}$ & $\begin{array}{l}\text { Shared the view that allowing } \\
\text { customers to partake in the product } \\
\text { development process introduces } \\
\text { different perspectives into the } \\
\text { approach adopted to develop new } \\
\text { products and hence leads to a higher } \\
\text { level of collective creativity. }\end{array}$ \\
\hline \multirow{3}{*}{$\begin{array}{l}\text { Influenced } \\
\text { factors }\end{array}$} & $\begin{array}{l}\text { Ritter and } \\
\text { Walter } \\
(2003)\end{array}$ & $\begin{array}{l}\text { Survey of } 233 \\
\text { manufacturing } \\
\text { companies }\end{array}$ & $\begin{array}{l}\text { Product } \\
\text { development }\end{array}$ & $\begin{array}{l}\text { Identified factors such as } \\
\text { commitment, trust, adaptation, and } \\
\text { relationship management, which } \\
\text { increase customer contribution to new } \\
\text { product design and functionality. }\end{array}$ \\
\hline & $\begin{array}{l}\text { Brockhoff } \\
(2003)\end{array}$ & Conceptual & $\begin{array}{l}\text { Product } \\
\text { development }\end{array}$ & $\begin{array}{l}\text { Discussed different issues related to } \\
\text { customer collaboration in product } \\
\text { development, such as locus of } \\
\text { initiative, customer contribution, and } \\
\text { effects of customer collaboration on } \\
\text { product success. }\end{array}$ \\
\hline & $\begin{array}{l}\text { Seybold } \\
(2001)\end{array}$ & Conceptual & $\begin{array}{l}\text { Product } \\
\text { development }\end{array}$ & $\begin{array}{l}\text { Noted that firms can deliver } \\
\text { significant value to the customer and } \\
\text { in return reap much greater loyalty if } \\
\text { they forge mutually beneficial } \\
\text { relationships. }\end{array}$ \\
\hline
\end{tabular}




\begin{tabular}{|c|c|c|c|c|}
\hline & $\begin{array}{l}\text { Coviello } \\
\text { and Joseph } \\
(2012)\end{array}$ & $\begin{array}{l}\text { Case study of } \\
\text { six technology } \\
\text { firms. }\end{array}$ & $\begin{array}{l}\text { Product } \\
\text { development }\end{array}$ & $\begin{array}{l}\text { Identified different roles customers } \\
\text { can adopt in product development, } \\
\text { such as source of latent needs, } \\
\text { requester, development customer, } \\
\text { early customer, technical advisor, co- } \\
\text { developer, approver, promoter, } \\
\text { sounding board, and critic. }\end{array}$ \\
\hline & $\begin{array}{l}\text { Peled and } \\
\text { Dvir } \\
(2012)\end{array}$ & $\begin{array}{l}\text { Case study of } \\
\text { multiple } \\
\text { product } \\
\text { development }\end{array}$ & $\begin{array}{l}\text { Product } \\
\text { development }\end{array}$ & $\begin{array}{l}\text { Proposed two customer styles- } \\
\text { design by and design for-arguing } \\
\text { that the advantages of customer } \\
\text { collaboration are dependent on the } \\
\text { product type. }\end{array}$ \\
\hline \multirow[t]{5}{*}{$\begin{array}{l}\text { Customers } \\
\text { roles and } \\
\text { relationship }\end{array}$} & $\begin{array}{l}\text { Blazevic } \\
\text { and } \\
\text { Lievens } \\
(2008)\end{array}$ & $\begin{array}{l}\text { Case study of } \\
\text { electronic } \\
\text { service } \\
\text { channels }\end{array}$ & $\begin{array}{l}\text { Service } \\
\text { innovation }\end{array}$ & $\begin{array}{l}\text { Demonstrated that customers can take } \\
\text { three different roles in knowledge } \\
\text { coproduction in innovation, namely, } \\
\text { that of a passive user, active informer, } \\
\text { and bidirectional creator. }\end{array}$ \\
\hline & $\begin{array}{l}\text { Nambisan } \\
(2002)\end{array}$ & Conceptual & $\begin{array}{l}\text { Product } \\
\text { development }\end{array}$ & $\begin{array}{l}\text { Proposed a theoretical framework that } \\
\text { relies primarily on the knowledge- } \\
\text { based view and defined different } \\
\text { customer roles in new product } \\
\text { development. }\end{array}$ \\
\hline & $\begin{array}{l}\text { Ulwick } \\
(2002)\end{array}$ & Conceptual & $\begin{array}{l}\text { Product and } \\
\text { service } \\
\text { innovation }\end{array}$ & $\begin{array}{l}\text { Posited that it is no longer sufficient to } \\
\text { gather customer requirements and } \\
\text { identify different types of information } \\
\text { such as solutions, specifications, } \\
\text { needs, and benefits, as customers must } \\
\text { be viewed as co-creators. }\end{array}$ \\
\hline & $\begin{array}{l}\text { Fang } \\
(2008)\end{array}$ & $\begin{array}{l}\text { Survey of } 143 \\
\text { customer- } \\
\text { manufacturing } \\
\text { dyads }\end{array}$ & $\begin{array}{l}\text { Product } \\
\text { development }\end{array}$ & $\begin{array}{l}\text { The author revealed that collaboration } \\
\text { with the customer as role of co- } \\
\text { developer or resource can have } \\
\text { negative effects on product } \\
\text { innovativeness when customer } \\
\text { network connectivity is high }\end{array}$ \\
\hline & $\begin{array}{l}\text { Fang et al. } \\
(2008)\end{array}$ & $\begin{array}{l}\text { Survey of } 188 \\
\text { manufacturing } \\
\text { firms }\end{array}$ & $\begin{array}{l}\text { Product } \\
\text { development }\end{array}$ & $\begin{array}{l}\text { Demonstrated that customer } \\
\text { collaboration can enhance the } \\
\text { effectiveness of product development } \\
\text { and increase the relation-specific } \\
\text { investment of firms and customers. }\end{array}$ \\
\hline $\begin{array}{l}\text { Effect of } \\
\text { customer } \\
\text { collaboration }\end{array}$ & $\begin{array}{l}\text { Lin et al. } \\
(2010)\end{array}$ & $\begin{array}{l}\text { Survey of } 107 \\
\text { computer } \\
\text { manufacturers }\end{array}$ & $\begin{array}{l}\text { Product and } \\
\text { service } \\
\text { innovation }\end{array}$ & $\begin{array}{l}\text { Revealed that customer collaboration } \\
\text { enhances market, service, and product } \\
\text { development. }\end{array}$ \\
\hline
\end{tabular}

\begin{tabular}{llll}
\hline Lau (2011) & $\begin{array}{l}\text { Survey of 251 } \\
\text { manufacturing } \\
\text { firms }\end{array}$ & $\begin{array}{l}\text { Product } \\
\text { development }\end{array}$ & $\begin{array}{l}\text { Discussed the contribution of both } \\
\text { customer and supplier in product } \\
\text { development, indicating that it can } \\
\text { have a significant effect on product } \\
\text { performance. }\end{array}$ \\
\hline
\end{tabular}




\begin{tabular}{|c|c|c|c|}
\hline $\begin{array}{l}\text { Lin and } \\
\text { Huang } \\
(2012)\end{array}$ & $\begin{array}{l}\text { Survey of } 179 \\
\text { high-tech } \\
\text { firms }\end{array}$ & $\begin{array}{l}\text { Product } \\
\text { development }\end{array}$ & $\begin{array}{l}\text { Demonstrated that customer } \\
\text { collaboration affects inter- } \\
\text { organizational relationships, which } \\
\text { have a negative effect on product } \\
\text { innovativeness, while positively } \\
\text { affecting process innovativeness. }\end{array}$ \\
\hline
\end{tabular}

While studies focusing on collaborative product development examine the way firms manage new product development, customer collaboration research aims to elucidate whether and how customer contribution can assist with different product development tasks and activities. Therefore, the theoretical framework adopted in the present study is aligned with the approaches adopted in the pertinent literature. The aim is to provide valuable insights into customer contributions and management of collaborative product development processes. The thesis expands the previous literature on customer collaboration by using a knowledge-based perspective to understand the challenges underlying customer collaboration. This perspective facilitates the understanding of the strategies and approaches that firms adopt in order to share knowledge and resources as a means of remaining competitive. Hence, the remaining sections of this chapter provide an overview of the knowledge-based view and examine the role of knowledge integration in collaborative product development processes.

\subsection{Collaborative product development with customers based on the knowledge-based view}

In the context of the present study, and building on a knowledge-based perspective, collaborative product development with customers pertains to the joint acquisition of knowledge and skills by firms and their key customers in order to achieve the common goal of developing a new product (Rindfleisch and Moorman, 2001; Wagner and Hogel, 2006; Homberg and Kuehnl, 2014). The outcome of this collaboration is value creation, which is maximized by utilizing distributed knowledge (Emden et al., 2006). In the context of product development, owing to the complexity of technology and market demands, knowledge often does not reside within one single firm, but is rather dispersed across different actors, including customers. Hence, firms need to forge relationships and collaborate with customers, by adopting approaches that facilitate knowledge integration.

This study adopted the theoretical lens of the knowledge-based view to understand when and how firms can integrate knowledge with customers. The decision to do so was validated through a detailed review of the available customer collaboration literature, which revealed a paucity of studies, especially those in which researchers adopted the knowledge-based view. Therefore, this study aims to fill the knowledge gap in this field, by applying this perspective to knowledge integration between firms and customers in collaborative product development. It is posited that with the use of purposive knowledge integration mechanisms, and by considering timing and the type 
of customer contribution, firms have the potential to enhance their innovation capabilities.

\subsubsection{Knowledge-based view and knowledge integration}

The main reason behind the adoption of the knowledge-based perspective is that, in today's economy, knowledge is the most important strategic resource that firms possess (Nonaka, 1994; Grant and Baden-Fuller, 2004), as it is vital for sustaining and creating competitive advantage (March, 1991). Considering this perspective, a firm would seek to establish collaborative relationships with other firms that are believed to have complementary knowledge. The focus on knowledge has been stressed in previous studies. For example, Hamel (1991) conducted a study on alliances among firms, revealing that Japanese firms were more motivated to collaborate with other firms than were European and US firms, which primarily sought ways to access knowledge others possessed. These findings were subsequently explored in more depth by other researchers, aiming to gain insight into knowledge management strategies that firms employ and the ways they approach organizational learning. One such study was conducted by Spender (1996), who subsequently argued that firms have a dual responsibility of generating and applying knowledge. According to Kogut and Zander (1992), this can be seen as a combinative capability of applying and acquiring new knowledge by capitalizing on existing knowledge. In line with this premise, firms that are able to leverage their internal knowledge in order to gain access to external knowledge benefit most from external collaborations. However, the success of this strategy is dependent on the firms' ability to bridge organizational boundaries, which is often challenging in practice. However, before understanding the challenges, it is important first to consider what is meant by "knowledge," what constitutes knowledge integration, and how it will be addressed in this thesis.

In the present study, the concept of knowledge is defined by conceptually differentiating knowledge from information. The term "information" usually pertains to a flow of messages, and is often necessary for dissemination (Machlup, 1978; Nonaka, 1994). In contrast, knowledge is anchored in the commitments and beliefs of individuals and guides their actions (Machlup, 1978). The concept of knowledge has been extensively explored in the context of different scientific fields. The distinction between tacit and explicit knowledge is arguably one of the most useful themes in the literature on knowledge-based view (Nonaka and Takeuchi, 1995; Spender, 1996; Grant, 1996). In this domain, the work of Polanyi (1966) remains relevant, as this author seems to have been the first to define the concept of tacit knowledge. Polanyi (1966) perceived tacit knowledge as personal knowledge that is attained through experience (i.e., skills, expertise, innovative ideas, and attitudes to problem solving). In contrast, explicit knowledge refers to the aspects of knowledge that can be readily articulated and presented in documents, manuals, and reports (Nonaka and Takeuchi, 1995; Spender, 1996). In the seminal work on the knowledge-based view of the firm, Grant (1996) referred to explicit knowledge as the outcome of articulating tacit knowledge 
that is readily captured. In organizational practice, both explicit and tacit knowledge are important, as they are complementary and form a closed loop of knowledge creation (Nonaka and Takeuchi, 1995).

A review of the literature indicates that most researchers concur that both explicit and tacit knowledge are interdependent, complement each other, and are necessary for production and competitive advantage (Brown and Duguid, 2001). In fact, an organization cannot compete in the market without the skills and experiences of individual employees, just as it cannot operate without techniques, procedures, and manuals. Therefore, both tacit and explicit knowledge are of interest for the present study, the aim of which is to elucidate how the two types are integrated in the context of collaborative product development.

However, while most authors agree on the equal importance of tacit and explicit knowledge, there is presently no consensus on what constitutes knowledge integration. In this respect, several definitions have emerged, most of them pertaining to a specific context (Berggren et al., 2011). Tell (2011) differentiated studies based on the manner in which knowledge integration is defined, namely, (1) as sharing or transferring knowledge (Huang and Newell, 2003; Marsh and Stock, 2006), (2) applying related knowledge (Teece and Pisano, 1994), and (3) as a combination of specialized and differentiated but complementary knowledge (Lin et al., 2006). In the context of interorganizational relationships in general, and in collaborative product development in particular, it has been argued that firms can gain knowledge through knowledge transfer (Beecham and Cordey-Hayes, 1998; Simonin, 1999; Kotabe et al., 2003; Squire et al., 2009). Knowledge transfer typically implies a one-dimensional flow between two actors (Berggren et al., 2011). Additional studies have indicated that that knowledge sharing can be crucial in gaining access to external knowledge bases (Wu and Lin, 2013; Yen and Huang, 2013). In contrast to knowledge transfer, knowledge sharing indicates revealing related knowledge without transmitting it in its entirety (Tiwana and McLean, 2005). It is important to note that, while both knowledge transfer and knowledge sharing are important for knowledge integration, these processes do not extend to combining different knowledge bases and generating new knowledge (Wijnhoven, 1998; Berggren et al., 2011). Adopting this more comprehensive view to collaboration with customers in product development implies that external knowledge bases need to be accessed, shared, and combined to create new knowledge. For instance, manufacturing firms need to access the complementary knowledge of their customers and combine this knowledge with their internal knowledge into developing product specifications, concepts, and prototypes of new products (Lukas and Ferrell, 2000).

In line with this, Okhuysen and Eisenhardt (2002) defined knowledge integration as the action of individuals who share and combine specialized knowledge to create new knowledge. They further argued that it is critical to distinguish between knowledge integration as a process and knowledge integration as an outcome. In this context, the 
outcome refers to sharing and combining knowledge, which occur through the process of knowledge integration resulting from collaboration (Okhuysen and Eisenhardt, 2002). Consequently, in the present study, knowledge integration is defined as a process in which specialized knowledge residing with the customer or the manufacturing firm, respectively, is shared and combined into new knowledge. In the context of collaborative product development, the thesis aims to extend the current understanding of knowledge integration. A particular emphasis is given to joint problem-solving activities that rely on a high degree of interaction among individuals. Problem solving refers to knowledge integration focused on the use of different knowledge types to generate, evaluate, and select relevant solutions by decomposing complex problems into more manageable issues that can be addressed more easily. In addition, it is explored whether knowledge integration can also focus on joint problem framing, i.e., gaining in-depth understanding of the problem at hand, and using the required knowledge to identify its different dimensions and causes, which necessitates a greater understanding of the whole (Brusoni, 2005). Table 2 presents an overview of the knowledge integration literature, along with the major insights each source provides on the subject. 
Table 2. Review of knowledge integration literature

\begin{tabular}{|c|c|c|c|}
\hline Study & Method & $\begin{array}{l}\text { Definition of knowledge } \\
\text { integration }\end{array}$ & Contribution \\
\hline $\begin{array}{l}\text { Grant } \\
(1996)\end{array}$ & Conceptual & $\begin{array}{l}\text { Knowledge integration as the } \\
\text { basis for the knowledge based } \\
\text { theory of the firm }\end{array}$ & $\begin{array}{l}\text { Efficient knowledge integration by } \\
\text { using multiple mechanisms such as } \\
\text { systems, documents procedure, and } \\
\text { group problem solving }\end{array}$ \\
\hline $\begin{array}{l}\text { De Boer et } \\
\text { al (1999) }\end{array}$ & $\begin{array}{l}\text { Conceptual } \\
\text { and case } \\
\text { study }\end{array}$ & $\begin{array}{l}\text { Knowledge integration as a } \\
\text { function of organizational } \\
\text { forms and capabilities }\end{array}$ & $\begin{array}{l}\text { Integrating design and architectural } \\
\text { knowledge relying on firm's } \\
\text { capabilities }\end{array}$ \\
\hline $\begin{array}{l}\text { Nonaka } \\
\text { and } \\
\text { Takeuchi } \\
(1995)\end{array}$ & Conceptual & $\begin{array}{l}\text { Creating new knowledge } \\
\text { through a process of } \\
\text { articulating, sharing, } \\
\text { combining, and absorbing }\end{array}$ & $\begin{array}{l}\text { Knowledge must spiral up from } \\
\text { individuals to groups and across firms } \\
\text { for its value to be recognized }\end{array}$ \\
\hline $\begin{array}{l}\text { Okhuysen } \\
\text { and } \\
\text { Eisenhardt } \\
(2002)\end{array}$ & Survey & $\begin{array}{l}\text { Knowledge integration is the } \\
\text { outcome of the process, which } \\
\text { "consists of both the shared } \\
\text { knowledge of individuals and } \\
\text { the combined knowledge that } \\
\text { emerge from interaction" (p. } \\
\text { 384) }\end{array}$ & $\begin{array}{l}\text { Knowledge integration by individuals } \\
\text { through three formal interventions: } \\
\text { information sharing, managing time, } \\
\text { and questioning others }\end{array}$ \\
\hline $\begin{array}{l}\text { Huang and } \\
\text { Newell } \\
(2003)\end{array}$ & Case study & $\begin{array}{l}\text { Knowledge integration as "an } \\
\text { ongoing collective process of } \\
\text { constructing, articulating and } \\
\text { redefining shared beliefs } \\
\text { through social interaction of } \\
\text { organization members" (p. } \\
\text { 167) }\end{array}$ & $\begin{array}{l}\text { Organization practices, previous } \\
\text { experience, and social capital define } \\
\text { the level of coordination, which can } \\
\text { influence efficiency }\end{array}$ \\
\hline $\begin{array}{l}\text { Tiwana and } \\
\text { MacLean } \\
(2005)\end{array}$ & $\begin{array}{l}\text { Survey } \\
\text { study }\end{array}$ & $\begin{array}{l}\text { Knowledge integration as "the } \\
\text { coordinated application of } \\
\text { individually held specialist } \\
\text { expertise in the } \\
\text { accomplishment of tasks at } \\
\text { the project level" (p. 17) }\end{array}$ & $\begin{array}{l}\text { Developing an expertise integration } \\
\text { view of team creativity and } \\
\text { operationalizing the concept of } \\
\text { expertise integration }\end{array}$ \\
\hline $\begin{array}{l}\text { Lin and } \\
\text { Chen } \\
(2006)\end{array}$ & $\begin{array}{l}\text { Survey } \\
\text { study }\end{array}$ & $\begin{array}{l}\text { Knowledge integration as "the } \\
\text { integration of complementary } \\
\text { assets and knowledge across } \\
\text { organizational boundaries for } \\
\text { developing market oriented } \\
\text { products and services" (P. } \\
\text { 159) }\end{array}$ & $\begin{array}{l}\text { Extent of cross-functional integration, } \\
\text { information sharing, and firm's } \\
\text { marketing (if technical skills positively } \\
\text { impact new product success) }\end{array}$ \\
\hline $\begin{array}{l}\text { Schmickl } \\
\text { and Kieser } \\
(2008)\end{array}$ & $\begin{array}{l}\text { Survey } \\
\text { study }\end{array}$ & $\begin{array}{l}\text { Knowledge integration as } \\
\text { "cross learning approach } \\
\text { which implies that groups of } \\
\text { specialists integrate their } \\
\text { specific knowledge which } \\
\text { encompasses different } \\
\text { concepts, methods, etc." (p. } \\
\text { 473). }\end{array}$ & $\begin{array}{l}\text { Three mechanisms of knowledge } \\
\text { integration (modularization, } \\
\text { transactive memory, and prototyping) } \\
\text { in combination explain coordination in } \\
\text { product development projects }\end{array}$ \\
\hline
\end{tabular}

\subsubsection{Challenges of knowledge integration in collaborative product development}

As previously discussed, a review of the pertinent literature revealed many reasons for firms to integrate knowledge in the collaborative product development process. The increasing risks and cost of innovation, for the development of more advanced technologies and increasingly complex products, have resulted in greater importance 
for knowledge integration. Firms need to access dispersed knowledge, rather than solely rely on proprietary expertise (Chesbrough, 2006; Grant and Baden-Fuller, 2004). Empirical evidence indicates that knowledge integration in product development has the potential to expedite the development of new products, since combining complementary knowledge and resources generates synergies, which can enhance effectiveness. However, while most firms acknowledge the importance of knowledge integration and the advantages of collaborative relationships, they typically encounter difficulties when attempting to integrate customer knowledge in collaborative product development.

One of the difficulties that firms face when integrating knowledge with their customers stems from the fact that knowledge typically resides with individuals and groups and can be challenging to document, quantify, and share (Nonaka, 1994). This is especially important in the context of integration of tacit knowledge, which relies on personal skills, making the integration processes even more challenging (Nonaka, 1994). In contrast, according to Grant (1996), explicit knowledge is easier to integrate, as it can be easily articulated and communicated. Grant (1996a) further asserted that the nature of knowledge, whether tacit or explicit, has different implications for the efficiency of knowledge integration. For example, the communicability of explicit knowledge makes it much easier to integrate relative to tacit knowledge, which requires continued dialogue and close collaboration. In this respect, Grant (1996a) proposed that communication of explicit knowledge should be kept at the minimum for knowledge integration to be efficient. This view was discussed by other researchers, such as Eisenberg (1990), who highlighted the danger of too much knowledge integration. Similarly, Lindkvist (2005) argued that knowledge integration can be achieved by wellconnected knowledge bases, rather than by aiming to maximize the level of communication.

Compared to explicit knowledge, which is easier to transfer, tacit knowledge is gained through experience and becomes innate skills of particular individuals. Furthermore, it is not easy to describe to others and can only be conveyed through personal communication. This is why Polanyi (1966) argues that tacit knowledge is difficult to transfer to others. As a result, most firms encounter difficulty when attempting to integrate tacit knowledge, as individuals usually know more than they are able to convey either verbally or in writing (Polanyi, 1966). Their innate abilities and attitudes toward work-related challenges, their colleagues, etc., are difficult to capture and quantify. In order to overcome these challenges, several approaches have been proposed, such as close integration, which relies on a high degree of communication. In collaborative product development projects, since the tasks are interdependent, different specialist skills and knowledge are required. In order to fully benefit from these interdependencies, multidisciplinary teams could be formed, whose members work together for integrating tacit knowledge (Nonaka and Takeuchi, 1995; Huang and Newell, 2003). This is particularly important for technology-based firms that employ staff with extensive knowledge, yet lack documentation pertaining to specific 
techniques and tasks that must be undertaken to solve problems that arise during product development. In this situation, correct inferences about former experiences and actions must be discussed in intensive interaction between individuals whose knowledge needs to be integrated.

Considering these challenges, the focus of knowledge integration does not necessarily need to be on reaching high levels of interaction only. Instead, the goal of knowledge integration should be to apply different mechanisms that enable the integration and combination of knowledge bases in relation to the needs created by the situational circumstance. This will be explained further when discussing different mechanisms that organizations can choose for this purpose.

\subsubsection{Knowledge integration mechanisms}

Grant (1996) has proposed several mechanisms for integrating knowledge and has related these to the costs that arise from the communication required for each mechanism. The first mechanism refers to the rules and directives contained in plans and procedures, which are considered as an impersonalized way of integrating knowledge. Coordinating activities in this way is relatively inexpensive and usually results in a reduced need for communication. The second mechanism is sequencing, whereby individuals integrate their specialist knowledge into a project, while minimizing dependencies. In a collaborative product development processes, this approach is usually applied, for example, to stage-gate processes (Cooper, 2008). The third mechanism is based on routines that are developed through accumulating experience (Zollo and Winter, 2002). The fourth mechanism refers to group problem solving for coordinating the individual sets of knowledge and experiences of all individuals. According to Grant (1996), while the first three mechanisms require less interpersonal communication, problem solving is a mechanism that relies on intensive communication and interaction.

In addition, Faraj and Sproull (2000) posited that knowledge must be integrated through appropriate mechanisms. These mechanisms need to address the challenges of knowing where relevant knowledge is located and identifying when it is needed and how it can be accessed. These mechanisms are necessary when the objective is to find "who knows what" and "where and when specialized knowledge" is required. They argue that smooth and informal interactions are important mechanisms through which necessary knowledge is identified and obtained at the right time. However, Faraj and Sproull (2000) also suggested other mechanisms based on structural devices that could be specified in advance, such as conducting regular meetings and creating milestones. Moreover, in the context of product development, Schmickl and Kieser (2008) have identified three knowledge integration mechanisms, namely, transactive memory, modularization, and prototyping. In their work, they studied how these three mechanisms relate to the degree of communication among specialists and integrating 
knowledge without having to intensely learn from each other. The aim of transactive memory is, in line with the arguments by Faraj and Sproull (2000), highly useful when searching for sources of highly specialized knowledge within or outside the organization (Grandori, 2001). In addition, modularization, builds on departitioning large, complex products into smaller parts in order to allow specialists to work independently on each of the subsystems. The main aim of this mechanism is to reduce the need for knowledge integration among customers and manufacturing firms. However, interaction with customers may be needed even when this approach is adopted as there often are unknown or emerging interdependencies (Mikkola, 2003). Therefore, in case of modularization, establishing customer needs and requirements is probably still required, as this allows firms to determine the required product functionalities and specify interfaces between the systems and components, as well as validate the feasibility of their interaction (Zirpoli and Camuffo, 2009). Prototypes, as the third mechanism noted by Schmickl and Kieser (2008), may help engineers to discover the specific challenges regarding a new product. Even though this mechanism may reduce some of the common communication challenges, its success is contingent on iterative problem solving with customers to integrate knowledge.

To sum up, most of the aforementioned mechanisms are essential in a contingency analysis, which helps to understand how each mechanism fits a specific context. It may also be important to understand how knowledge integration mechanisms are used and change throughout a product development process. According to Tell (2011), few studies focus on the activities and dynamic processes of knowledge integration in an innovation context. Extending this to customer collaboration in product development processes, having dynamic processes for integrating knowledge with customers into the development process could be important. This is due to the fact that existing collaborative product development processes need to become more flexible (Engwall and Westling, 2004; Faraj and Xiao, 2006). This would allow firms to make use of customer's knowledge continuously rather than at specific points in time. Therefore, one of the aims of this study is to understand how the mechanisms for knowledge integration with customers may change during development processes in response to evolving challenges.

In the next section, customer contribution and customer collaboration are connected to the phases of the development process. In addition, mechanisms for knowledge integration in these phases are discussed. The next section is based on the argument that existing product development models and stage-gate systems need to be partly revised by systematizing the process of capturing external knowledge and leveraging opportunities to integrate knowledge with customers in line with Gronlund et al. (2010).

\subsection{Customer collaboration in product development processes}

The effect of customer collaboration in product development projects cannot be 
discussed without describing the process of product development. In fact, rather than relying on general guidelines, this study first elucidates the process through which a partnership with customers leads to product development success. In practice, most firms are also interested to know how they can benefit from customer collaboration in their development projects. A literature review of different methods of and approaches to customer collaboration in development projects suggests a broad range of solutions. In reviewing this literature, it is clear that manufacturing firms need to consider different issues, such as when customers need to be involved and to what extent their contribution should be sought in the development process.

\subsubsection{When should a firm collaborate with customers?}

It is essential to establish when customers can provide a meaningful contribution in the product development process. This concerns the phases of the product development process. Empirical evidence indicates that customers can contribute different skills and inputs in the various product development phases (Kaulio, 1998; Lagrosen, 2005; Lin and Huang, 2012). Through the phases of the product development process, different innovation problems emerge and need to be resolved before proceeding to the next step (Cooper, 2008; Gronlund et al., 2010). According to the idea of the stage-gate system (Cooper, 2008; Cooper and Edgett, 2012), the product development process can be divided into different stages. This approach is widely used, but represents a somewhat sequential perspective to product development. Although the division into different stages can help to control product development projects, it should be noted that product development often build on iterative processes (e.g., Eisenhardt and Tabrizi, 1995). Nevertheless, from a conceptual point of view, product development might be divided into phases in order to describe how the focus of product development evolves through its stages.

Laage-Hellman et al. (2014) asserted that views vary regarding the specific product development phase in which customers can contribute. Some researchers claim that customers need to contribute as "early as possible" (e.g., Kaulio, 1998). In the early phases, i.e., the ideation or concept development, customer collaboration is typically restricted to identifying customer needs and differences in skills stemming from creative ideas (Millson and Wilemon, 2002). In addition, some researchers argue that customer contribution is also required in subsequent phases. Lagrosen (2005) and Lin and Huang (2013) are among those claiming that firms need to collaborate with customers in the development phase as well, as this leads to a better implementation of customer expectations. Similarly, customer collaboration in the later phases, such as test phase, can help manufacturing firms assess the new product (Aarikka-Stenroos and Jaakkola, 2012; Blazevic and Lievens, 2008). Despite these positive views, some concerns have also been raised regarding customer collaboration in the product development phases (Gatignon and Xuereb, 1997; Christensen, 1997). These indicate that customer collaboration in the development phases requires further consideration, 
thus highlighting the need for further studies in this field, especially those focusing on knowledge integration.

\subsubsection{Customer roles}

In order to understand the extent of customer contribution in collaborative product development, authors of previous studies have identified a wide range of different roles customers can adopt. These are discussed below.

Customer as lead user: The lead user approach is widely adopted by firms aiming to define the problem and solution statement, as well as find new product ideas and select the most attractive trends (von Hippel, 1986; Herstatt and von Hippel, 1992; Lilien et al., 2002; Olson and Bakke, 2001). In this approach, product idea generation differs from that adopted in traditional marketing strategies due to the type of input sought and information collected. More specifically, firms adopting the lead user approach seek input from the customer on both the needs and potential solutions, whereas the traditional marketing approach is employed when firms aim to obtain customer requirements only (Griffin, 1997; Lilien et al., 2002).

Customer as resource: In most cases, the customer is perceived as a resource, providing a manufacturing firm with valuable information and new product ideas (Coviello and Joseph, 2012; Fang et al., 2008). However, empirical evidence shows that, when the customer is treated as a resource, this does not necessarily equate to a significant contribution to the development process. It seems that, in many cases, the customer may lack knowledge of the development process, which then becomes firm driven, and the customer merely provides input pertaining to needs and requirements (Kaulio, 1998).

Customer as co-creator: In some collaborative partnerships, a customer acts as a cocreator of new products (Nambisan, 2002). In such cases, the customer and the manufacturing firm are active partners in the development process (Huang and $\mathrm{Chu}$, 2010; Wu and Lin, 2013). In this type of collaboration, the customer is considered as an important source of product- and design-specific input and is highly involved in the problem-solving logic and processes (Rosell and Lakemond, 2012). This interaction pertains to a wide range of activities, such as diagnosing needs, designing and producing solutions, managing value conflicts, and solution implementation (AarikkaStenroos and Jaakkola, 2012). Therefore, in this context, the customer is seen as a codeveloper who is actively engaged in every aspect of product design and development, alongside the supplier (Fang, 2008; Blazevic and Lievens, 2008).

Customer as user: According to Nambisan (2002), when the customer adopts the role of a user, developers benefit from immediate and direct feedback that can be incorporated in the subsequent product development and refinement initiatives 
(Blazevic and Lievens, 2008). As Lagrosen (2005) stated, such a relationship between the firm and the customer is facilitative, as both parties are willing to invest in common activities and contribute necessary resources in order to increase the benefits of the relationship while reducing costs and mitigating risks. Customer as user increases a firm's product launching capabilities and contributes positively to product development success (Kandemir et al., 2006).

Customer as reference point: In this approach, customers are given the opportunity to test the new product prototype or earlier version of the product and are asked to share their experience with the manufacturing firm (Brockhoff, 2003). This enables firms to receive customers' inputs on the product application. Firms use this approach to motivate new customers, with reference customers acting as spokespeople for the firm's products (Helm and Salminen, 2010).

The roles of customers and their presumptive contributions to the development process are outlined in table 3 . The contribution of customers can vary with the phases of the product development process depending on their roles. For example, when customers act as lead users, they could arguably offer new ideas, which implies that customer collaboration is more suitable in the early phases. However, when customers are considered as reference users, their contributions could be more relevant in the later phases of product development. Thus, it can be argued that the role of a customer provides some insight into the timing of customer collaboration. In addition, customer contribution expectedly depends on different factors, some of which are discussed in the next section. 
Table 3. Literature review on roles of customers

\begin{tabular}{|c|c|c|}
\hline Study & Customer roles & Customer contribution \\
\hline $\begin{array}{l}\text { Von Hippel (1986, } \\
\text { 1988); Lilien et al } \\
\text { (2002); Olson and } \\
\text { Bakke (2001) }\end{array}$ & Lead user & $\begin{array}{l}\text { - } \quad \text { Defines problems and solutions } \\
\text { - } \quad \text { New ideas according to trends }\end{array}$ \\
\hline $\begin{array}{l}\text { Nambisan (2002); } \\
\text { Coviello and Joseph } \\
\text { (2012); Fang et al } \\
\text { (2008); }\end{array}$ & Resource & $\begin{array}{l}\text { - } \quad \text { Minor contribution to product development } \\
\text { - } \quad \text { Provides relevant information about needs and } \\
\text { business characteristics }\end{array}$ \\
\hline $\begin{array}{l}\text { Nambisan (2002); } \\
\text { Aarikka-Stenroos and } \\
\text { Jaakkola, (2012) Peled } \\
\text { and Devir (2012) }\end{array}$ & Co-creator & $\begin{array}{ll}\text { - } & \text { Diagnoses needs } \\
\text { - } & \text { Contributes in designing and producing tasks } \\
\text { - } & \text { Validates system engineering } \\
\text { - } & \text { Manages value conflicts and solution } \\
\text { implementation }\end{array}$ \\
\hline $\begin{array}{l}\text { Nambisan (2002); } \\
\text { Blazevic and Lievens } \\
(2008) ; \text { Kandemir et al } \\
(2006) ; \text { Blazevic and } \\
\text { Lievens (2008) }\end{array}$ & User & $\begin{array}{l}\text { - } \\
\text { - } \\
\text { Maintenance requirements and repair } \\
\text { demands }\end{array}$ \\
\hline $\begin{array}{l}\text { Brockhoff (2003); } \\
\text { Helm and Salminen } \\
(2010)\end{array}$ & Reference & $\begin{array}{l}\text { - Source of information about the application of } \\
\text { the new product }\end{array}$ \\
\hline
\end{tabular}

\subsection{Factors related to customer collaboration in product development}

The literature on customer collaboration indicates that it is important to consider the manufacturing firm's as well as the customer's characteristics in determining the setup of collaborative product development projects (e.g., Gruner and Homburg, 2000). Empirical evidence also indicates that the firm's technical capability is an important factor to consider. In addition, the commitment and willingness of the customer to collaborate should not be overlooked, as they also can have an effect on the outcome of collaboration (e.g., Krause et al., 2007). These two aspects are further discussed in the following sections.

\subsubsection{Technical capability}

The role of the firm's technical capability is widely discussed in the context of collaborative product development. For example, a survey of 494 manufacturing firms, conducted as part of four different studies, has shown that technical capability is one of the most important criteria for the success of collaborative product development (Rundquist and Halila, 2010). In this context, a firm's technical capability refers to the knowledge and expertise related to the relevant technology, as well as its ability to foresee how it will evolve in the future (Wagner and Hoegl, 2006; Wynstra, et al., 2010). Innovative firms must focus their efforts on continuous technology development and ensure that they can adapt to emerging technologies. This will enable them to meet customer needs in the long term. In most firms, technical capability is embodied in individuals working for the organization. The ability to adapt to emerging technologies 
and use these in the development of new products is considered as the key factor in collaborative relationships (Ngo and O'cass, 2009). The importance of technical capability is also highlighted from a knowledge-based perspective. If a firm's technical capability is insufficient, it will not be able to realize the technology's potential, discover the complementarities of internal and external knowledge, and integrate this knowledge inter-organizationally. In fact, firms that are capable of incorporating external technology into the new product are ideally positioned to pursue knowledge integration in collaborative product development. However, it has been argued that firms need to be avoid a situation in which customer collaboration influences the innovative direction into the needs of only existing customers (e.g., Leonard, 2002). This may limit the degree of innovation and would be a disadvantage for firms that attempt to discover the possibilities of a high degree of innovation.

\subsubsection{Internal integration capability}

The success of collaborative product development depends on not only the technical capability of the firm but also its internal capability to contribute to the product development processes. In this context, internal integration capability refers to the internal activities for assimilating external knowledge. This is in line with the concept of absorptive capacity, which refers to the use of internal knowledge to assimilate and apply external knowledge (Cohen and Levinthal, 1990). The importance of internal capability for achieving external knowledge integration has been discussed by many authors. For example, Dobler and Burt (1996) posited that technical activities, such as conceptualizing the product, determining product requirements, reviewing and updating production schedules, and defining manufacturing processes, are key aspects of a firm's internal capability. As these activities are interrelated, they should be managed in an integrated manner by internal functional units, including marketing, manufacturing, R\&D, and purchasing (Dowlatshahi, 1998; Gerwin and Barrowman, 2002).

Ample empirical evidence supports the view that external collaboration and internal integration are intertwined and need to be considered simultaneously in order to derive greater benefits from collaborative product development (Droge et al., 2004; Koufteros et al., 2005; Hillebrand and Biemans, 2004; Mishra and Shah, 2009). However, authors of previous studies exploring internal integration within the field of collaborative product development typically focus on cross-functionality (e.g., Song et al., 1997; Wheelwright and Clark, 1992). Thus, their findings provide support for crossfunctional integration in general, without specifying the most appropriate degree of integration in various conditions (e.g., Swink, 1999; Song and Xie, 2000).

\subsubsection{Customer commitment}

Commitment is recognized as an important aspect of most inter-organizational 
relationships (Moorman et al., 1992; Garbarino and Johnson, 1999), as it enables smooth collaboration between trading actors (Skarmeas et al., 2002). Commitment indicates strong motivation of firms to invest in the relationship with their partner (Geyskens et al., 1996), as well as a desire to continue the relationship into the future (Moorman et al., 1992).

In the existing literature, firms often see their relationships with customers as a specific investment that can help them improve performance (e.g., Krause, 1999). When customers are reluctant to commit to a long-term relationship, firms are unlikely to be willing to invest resources into relationship development (Krause et al., 2007). However, if a customer signals strong commitment to a long-term relationship, firms are motivated to contribute time and resources to forging stronger ties with customers. However, customer commitment cannot be viewed in isolation, as it is contingent on the attitude the firm has toward the partnership. Research has shown that customers are more eager to collaborate with manufacturing firms that are more capable of involving their customers in product development (e.g., Walter, 2003). In turn, this commitment is usually reflected in the customer's willingness to contribute to product development. Therefore, mutual commitment is needed in inter-organizational relationships, as it improves flexibility and mutual trust (Ritter and Walter, 2003).

According to Muthusamy et al (2008), reciprocal commitment of resources by the partners will also enable a high degree of knowledge integration. A commitment based on the sharing of resources and personnel between customers and manufacturing firms can improve knowledge integration (Inkpen and Dinur, 1998). Such collaborative relationships are highly beneficial to both parties, as actors in inter-organization relationships not only learn about each other, but can also develop capabilities and create new competencies (Dyer and Nobeoka, 2000).

\subsection{Summary of the literature}

Research in the field of collaborative product development with customers is not new. There are many contributions, and the advantages of customer collaboration in relation to gaining knowledge is commonly brought up. However, few studies explicitly study customer collaboration in product development from a knowledge-based perspective. The research studies discussed in this chapter are chosen to elucidate the importance of knowledge integration with customers during the product development process. Existing studies suggest that firms need to share and gather customer knowledge (e.g., Lukas and Ferrell 2000), as well as combine it with product-specific knowledge, as a way of creating new knowledge (Okhuysen and Eisenhardt, 2002). The review of the literature on mechanisms and activities for knowledge integration reveals that the use of these mechanisms might be subject to a contingency analysis (e.g., Grant, 1996; Faraj and Sproul, 2000). Further insights into the use of these mechanisms are necessary. One main limitation of the existing body of research is that very few studies 
have analyzed the dynamics of knowledge integration with customers during the course of product development.

Similarly, most of the previous studies on customer collaboration focus on benefits and challenges (Gatignon and Xuereb, 1997; Lilien et al., 2002; Callahan and Lasry, 2004; Brockhoff, 2003; Callahan and Lasry, 2004; Bonner, 2010), along with approaches that can be adopted to support customer collaboration, such as lead user (von Hippel, 1986), quality function deployment (Akao, 1990), and others. In addition, most authors tend to emphasize collaboration with customers in the early phases of the development process (von Hippel, 1976; Griffin and Hauser, 1993; Billington, 1998; Thomke and Fujimoto, 2000; Paustian 2001; Dahan and Hauser 2002). Therefore, approaches and mechanisms for obtaining contributions from customers during the development process are presently lacking. Moreover, the authors of available studies exploring customer contributions tend to discuss the different motives and roles of customers during product development (von Hippel, 1986; Nambisan, 2002; Fang et al., 2008; Blazevic and Lievens, 2008; Coviello and Joseph, 2012). However, they fail to address the manner in which customers' knowledge contribution can evolve through the phases of the product development process. Thus, they also fail to elucidate how situational factors can influence knowledge integration with customers. 


\section{Research Methodology}

In this chapter, the methodological choices are described. The chapter commences with an overview of the research process and research design. This is followed by an overview of the case study approach, which includes case selection, data collection, and qualitative data analysis. The survey study approach is discussed next, along with the selection and measurement of the constructs, and the data analysis techniques. Finally, the chapter ends with a clarification of the empirical studies in relation to the papers and the authorship of each of the papers.

\subsection{Research Process}

In the beginning of my $\mathrm{PhD}$ studies in 2011, I was encouraged to research knowledge integration in customer-supplier collaborations. As I was interested in the subject, and could see the benefits of understanding knowledge integration with customers better, I was motivated to delve into my $\mathrm{PhD}$ studies. I was particularly interested in understanding how knowledge integration could be achieved between firms and their customers and what roles customers could play in this endeavor. I found that, while existing research indicates the importance of knowledge integration among firms, there is paucity of studies on the integration of knowledge in this context.

Due to the initial explorative nature of the study, I decided to design and adopt a case study approach to identify how firms integrate knowledge with customers in product development. In order to conduct the case study, I started writing a proposal with the aim of studying knowledge integration between firms and their customers

I initially intended to explore this concept from a rather broad perspective, aiming to first establish if the topic is relevant for a manufacturing firm as well as a customer, and if so, to seek their perspectives on the challenges that they face. I approached two large international firms, which fortunately agreed immediately to participate in my study. I refer to these two firms as ROLIND and MEDCOM. Both firms indicated that knowledge integration with their customers is important for them, while they also faced some challenges when attempting to fully benefit from this collaborative effort. In my investigation, I focused on ascertaining how customer knowledge is accessed and integrated as part of the product development process. The resulting study at ROLIND and MEDCOM is presented in the appended Papers 1 and 2, while the method used in the research execution will be described in detail in Section 3.4 of this thesis.

While I was still conducting my research at ROLIND and MEDCOM, I decided to also utilize and reinterpret the empirical data from my master thesis study, which I had conducted in the Elekta company. The analyses performed resulted in Paper 3, which is titled "Internal integration in complex collaborative product development projects." The paper highlights the importance of internal integration in customer-supplier 
collaborations. The data were gathered during a 9-month-long internship that I carried out during my master studies, aiming to understand how customers work together with their suppliers in product development.

The ROLIND and MECOM studies and the Elekta paper formed the basis for the licentiate thesis that I presented in 2014. After my licentiate, I worked for an additional two and a half years on my research. During this period, I had the intention to validate some of the findings from the case studies through a quantitative survey study. The motivation behind this approach was the need to test the relationships among different constructs that were identified based on the existing literature, as well as those that emerged in the ROLIND and MEDCOM case studies. In pursuing the next phase of my studies, I aimed to explore knowledge integration with customers, in relation to the different phases of the product development process and several situational factors. This focus was further motivated by the limited empirical evidence available on the relationship between knowledge integration with customers and innovation performance. Therefore, in the fall of 2013, I designed a survey study aiming to investigate collaboration between manufacturing firms and their main customers in product development projects, in general, and the relationship between knowledge integration with customers and innovation performance, in particular. Some results from the survey study are provided in the appended Papers 4 and 5, while the study methodology is discussed in Section 3.5 of this thesis.

\subsection{Research design}

A research design includes carefully selected research approaches that are appropriate for meeting the goal of a study. It is important to select the most-relevant approach, since the data collection and analysis techniques must align with the study objectives. In choosing the study methodology, benefits and shortcomings of several approaches are usually considered (Bryman and Bell, 2007). Johannessen (2009) discussed the advantage of applying several approaches in the research projects investigating the elements of creating innovation in organizations and social systems. In addition, others advocate multi-method approaches. Inspired by this, this work builds on two main research approaches (a multiple case study and a survey study). In addition, the thesis is a compilation of different papers that provide multiple perspectives on the phenomenon being explored. The unit of analysis for the case study approach was the collaborative product development project. In order to validate the findings from the case studies and increase the possibility of generalization of the findings, a larger sample was required. In contrast to the case study, the survey study addresses knowledge integration in collaborative product development with customers at the firm level. That is, it was assumed that knowledge integration mechanisms and practices are imprinted in a firm's routines and apply to all product development projects. 
The study was informed by an extensive review of pertinent literature, which helped identify limitations in the existing knowledge and situated the current study in the body of pertinent work in this field. The results of the literature review served as a theoretical foundation for the present study. This approach ensured that suitable cases were included, thereby allowing a much richer understanding of the phenomenon collaborative product development with customers (Dubois and Gadde, 2002).

The results of the case studies and the survey study are reflected in the five appended papers. All five papers contribute to fulfilling the purpose of this thesis, namely, understanding the process of knowledge integration with customers in collaborative product development. The research design and the different activities that are performed throughout the process are shown in Figure 1. As can be seen, the study commenced by defining the theoretical framework; and was followed by the multiple case study. Thereafter, the survey study was conducted. Finally, the results of all the studies were analyzed in order to synthesize the findings and reach the conclusion related to the overall purpose. It must be noted that Figure 1 depicts the research design and not the process of research. Throughout the research study, some of the activities were conducted in parallel, some sequentially, and some overlapped each other. For instance, the literature searches and review were performed alongside the case studies and survey study, which allowed the researcher to revise data collection by being flexible (cf. Eisenhardt, 1989)

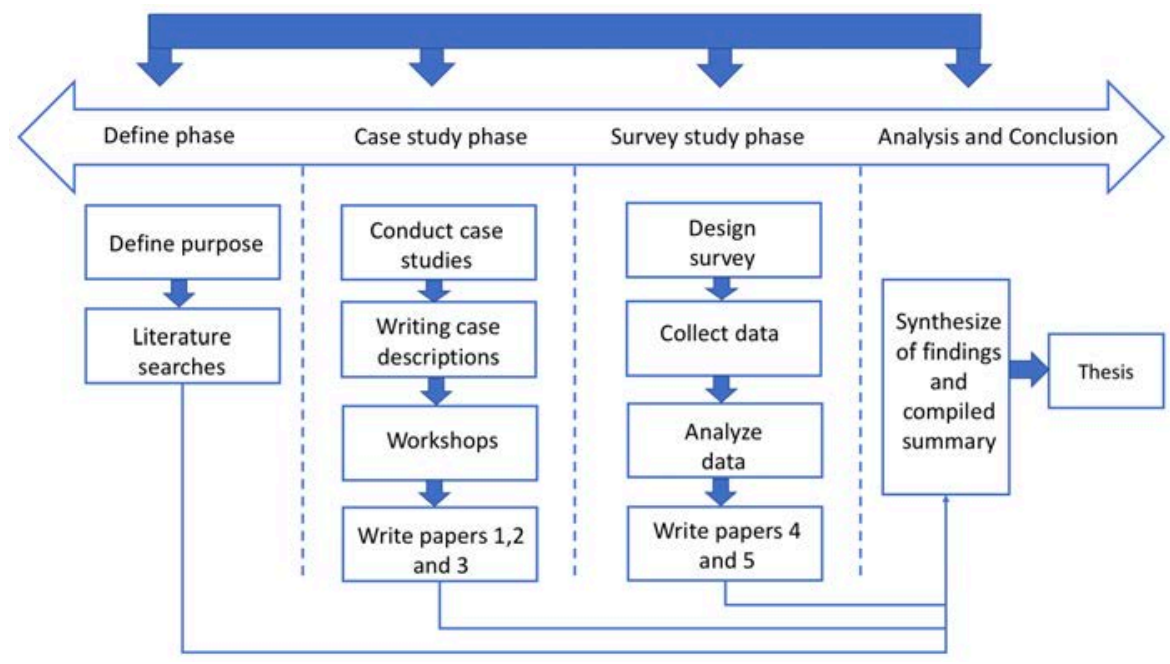

Figure 1. Overview of research design

\subsection{Defining the focus of the study and the literature review}

While the main focus of the study never changed, as the study progressed, different research ideas and questions emerged, such as "What knowledge do customers 
contribute?" "When does their input appear during the product development process?" and "How can customer's knowledge be integrated?" Guided by the overall purpose of the study, I initially conducted a literature search, in order to identify the most suitable approach for developing a general theoretical framework. In addition, exploring pertinent literature helped to define the study in its context, including theories, concepts, and themes.

The literature review also allowed me to identify gaps in previous knowledge as a means of situating the present study and ascertaining its value. When searching for relevant literature sources, I utilized keywords such as "knowledge integration," "collaborative product development/innovation," "customer collaboration/ involvement," and "customer-supplier collaboration," among others. Most of the literature sources were identified through using databases such as Google Scholar and Business Source Premier. These provide a comprehensive coverage of peer-reviewed journals. In addition, my review included some hard copies of published works, electronic books, and doctoral dissertations relevant to the purpose of the study.

After identifying relevant sources, I read the abstract of each article in order to assess its relevance to the present study. In addition, I perused the references sections of each publication to look for other potentially relevant studies. Using this strategy, I identified 131 articles, 30 of which were related to the knowledge integration concept (not necessarily related to customer collaboration), while 65 explored customer collaboration and relevant situational factors, and the remaining 36 concerned collaborative product development/innovation in general. Although this provided an important initial basis for the study, additional literature was gathered throughout the research process and included in the study. Some of these came to my attention rather accidently, while others were the result of purposive searches, for example, in the course of writing the appended papers.

\subsection{Case study approach}

In order to investigate how firms integrate knowledge with their customers in product development, I conducted case studies at two manufacturing firms. A multiple case study was selected as a suitable approach for investigating knowledge integration with customers in collaborative product development. Knowledge integration, especially in the context of inter-firm relationships, is a complex phenomenon affected by multiple variables. According to Yin (2009), case studies allow researchers to gain a more detailed understanding of these types of complex phenomena and processes in their real-life contexts.

In this work, the case study approach is used in the research presented in Papers 1, 2, and 3. The aim of Paper 1 was to develop an understanding of customers' knowledge contributions, as well as the timing of knowledge integration with customers. In this 
part of the study, the use of multiple cases facilitated a comparison among the cases to discover the situational factors that can affect customers' knowledge contribution in product development projects. Paper 2 presents a single case study, as this was deemed an appropriate approach for attaining deep insights into dynamic characteristics of knowledge integration processes with customers. As Flyvbjerg (2006) argued, a single case study allows researchers to identify with the specific issue being studied, thus providing an in-depth understanding of the phenomena being explored. Consequently, using a single case study as the main approach in this paper provides the advantage of a consistent empirical setting, which permitted a detailed analysis of how a firm can integrate knowledge with its customers in different product development phases. Similarly, a single project with different subsystems, presented in Paper 3, allows establishing variations in internal integration approaches in customer-supplier collaboration.

\subsubsection{Firm selection for case study}

The selection of firms in which case studies would be conducted commenced by identifying manufacturing firms that would provide a suitable setting for investigating the process of customer knowledge integration in product development. Two manufacturing firms, ROLIND and MEDCOM, were selected.

ROLIND employs around 50,000 staff globally, and has R\&D centers located in different countries, with around $5 \%$ of the total annual budget dedicated to R\&D. ROLIND develops an extensive variety of technologies based on different platforms used in various industries. ROLIND is a world leader in its field and has a long tradition of product development. ROLIND won the Swedish innovation awards in 2009, and the company goal is to combine the existing and new technologies to create new market demands.

MEDCOM has almost 49,000 employees worldwide and has business activities in more than 130 countries. MEDCOM brings various technologies in four different areasconstruction, material technology, machining solutions, and mining. MEDCOM has a long-standing reputation for providing significant R\&D investment for product development. The company also adopts a specific approach to product development projects, whereby R\&D engineers work closely with customers to jointly discover all the potential challenges of the new product.

The two manufacturing firms were selected because of mainly two reasons. First, they are well-performing firms with strong technical capabilities and bargaining power in collaborative relationships with customers. Second, they are both striving to benefit further from integrating knowledge with customers in collaborative product development and would thus benefit from taking part in the present study. After the managements of both ROLIND and MEDCOM evaluated the study proposal, they 
invited me and my supervisor to present the study objectives and explain the nature of their participation. Once they agreed to allow me to conduct case studies at their premises, I began my research on site.

As an additional company, and through reinterpretation of data gathered during my master's thesis, Elekta features as a third company in this doctoral thesis. Elekta has almost 3,600 employees worldwide and business activities in more than 29 countries. Elekta is a human care company that provides significant innovations and clinical solutions for treating cancer and brain disorders that are currently in use in over 6,000 hospitals worldwide. In 2015, the company increased its R\&D investment by more than $20 \%$. It has an extensive product development program focusing on different solutions and projects.

\subsubsection{Case selection}

In collaboration with the three companies briefly introduced above, five product development projects were selected for inclusion in this investigation. I studied two development projects at ROLIND and two at MEDCOM, along with one project at Elekta. The sampling of the appropriate cases in this thesis was purposeful, allowing me to obtain deep insights into the phenomenon. The strategy utilized for case sampling aimed to reveal cases demonstrating the process of knowledge integration with customers. In ROLIND and MEDCOM, the case selection was also guided by the representatives of the firms. During our discussions, we informed them of our sampling criteria, such as (1) projects characterized as knowledge intensive, in the sense that they require integration of different knowledge bases, and (2) projects requiring different forms of customer contributions and diverse customer roles. While the same strategy was used for the Elekta case, the data related to the studied project was mainly utilized in the analysis of potential variations in internal integration approaches in a collaborative product development context. More details of the sampling procedure employed in each firm are provided in the discussion on data collection in Subsection 3.4.2. An overview of the firms' background information and cases chosen for this investigation is provided in Table 4. 
Table 4 Key data from cases

\begin{tabular}{llll}
\hline & ROLIND & MEDCOM & Elekta \\
\hline Profile & High-tech & High-tech & High-tech \\
\hline No. of employees & 44500 & 50000 & 3400 \\
\hline $\begin{array}{l}\text { Sales } \\
\text { (Billion Euro) }\end{array}$ & 7.5 & 10.4 & 0.15 \\
\hline Cases & Mono and Solar & Fra and Implant & Muse \\
& New Product & New Product & New Product \\
\hline Project duration & Mono: 2.5 years & Fra: 3 years & 2 years \\
& Solar: 2 years & $\begin{array}{l}\text { Implant: Around } \\
\text { years }\end{array}$ & \\
\hline Project participants & $8-10$ & $8-10$ & 12 \\
\hline
\end{tabular}

\section{Mono}

ROLIND developed the Mono project, which is a system solution for heavy production equipment used in steel production industries. The Mono system contains different components and subsystems that are continuously exposed to the harsh environment and an extremely heavy load of steel production. ROLIND was the supplier, which delivered Mono systems to customer. The customer demanded the project from ROLIND, which was a distinctive solution in the market. The customer chose to select the Mono solution after the preliminary examination of ROLIND's proposal, among the applications from competitive suppliers. The customer has previously operated different technical solutions for steel-producing machines, and could be considered as having high technical knowledge.

\section{Solar}

ROLIND also developed a solar tracking system to be installed in a tracker product, called the Solar Tracker. The Solar project focused on designing an integrated system, including different components and other important technologies with ROLIND. The project is rather new to ROLIND and is based on a new market offering for which there is a high request. ROLIND created integration with a number of customers for the Solar project. The customer has set up the tracker product on its site and has extensive technological knowledge in the field related to the solar system. Accordingly, the customer played a profound role in contributing to the concept of the product and supports ROLIND in testing the Solar Tracker.

\section{Implant}

MEDCOM developed a new material project (Implant) for implantation in the human body. The Implant material has led to an extensive request for reliable performance in a variety of medical applications. The project was requested for by the customer, who exposed MEDCOM's capability through a collaboration with the university. Their 
request was to develop an implant with a new material used in the market. The project was complicated, and required different skills and knowledge in the development process. The customer played a key role in the development of the Implant project, but their knowledge of mechanical testing and actual machining was somewhat limited.

\section{Fra}

Fra is a distinctive cobalt chrome product from MEDCOM, which has the potential for practical use in the medical field. The concept for the project was instigated by the R\&D department at MEDCOM. During the ideation stage, MEDCOM was in contact with the customer to develop the product. The customer is new in the market but willing to order a large volume of Fra from MEDCOM. Customer contributions to the development of the product varied from moderate in the ideation phase to limited in the detailed development phase.

Muse

The Muse project is a new product from Elekta that implements new functionalities, containing multiple sessions of brain cancer treatment. The Muse project is employed to provide target localization and fixation of the patient's head in a Gamma Knife machine. The project included five different subsystems that served as the new platform, and was used in a new application, which requested the functionality to be much improved in order to satisfy the high-performance requirements. The subsystems interlink to each other, and only one supplier was involved for each subsystem.

\subsubsection{Data collection}

In the case studies, I used different data collection methods, namely, interviews, workshops, informal discussions, and secondary data, which allowed data triangulation. This is in line with the view of researchers, who posit that data triangulation and applying different data collection methods increases the validity of the findings (Golafshani, 2003).

When conducting interviews with the representatives of the three companies, I utilized a semi-structured interview protocol, which allowed me to support predetermined interview questions with additional queries that would prompt a more detailed discussion in order to explore issues participants raised during our conversation. Semistructured interviews allow a more flexible discussion and can include follow-up questions if necessary. During the data collection process, I conducted 46 interviews with the representatives of the three companies. Most of the interviews were conducted individually, while in some cases two or three interviewees were interviewed jointly if they worked on the same project (see Tables 6 and 7 for more details). Most interviews were conducted face-to-face, while a few interviewees preferred to use Skype. The 
interviews allowed me to obtain the required information, and thus gain in-depth understanding of the phenomenon of interest. When answering questions, the interviewees provided useful and rich information. Furthermore, depending on the type of questions and the responsibility of the interviewees, the interviews lasted from one to more than three hours and were recorded and subsequently transcribed. An overview of the interviews is provided in Table 5.

In addition to the interviews, we conducted three workshops at MEDCOM and ROLIND at the beginning and the end of the study. The workshops contained different elements, such as presenting the research idea and the results and engaging in a discussion with the participants. These discussions allowed us to evaluate and validate the study findings and identify any future steps, while permitting the participants to share their comments and feedback. In addition, I gathered secondary data in the form of documents and factory visits in order to gain a better understanding of these companies and their projects. The secondary data include project specifications, project models, project creation processes, patenting activities, company reports, and financial data. During the visits to MEDCOM and ROLIND, I was also given a tour of the factory and the R\&D department, allowing me to observe processes involved in the development of some of the products I studied.

Table 5. Interview overview

\begin{tabular}{llll}
\hline Firm & Number of interviews & Interview time & Time duration \\
\hline ROLIND & 19 & 34 hours and 25 min & 18 months \\
\hline MEDCOM & 9 & 14 hours and 32 min & 9 moths \\
\hline Elekta & 18 & 30 hours 30 min & 8 months \\
\hline Total & 46 & 80 hours and 36 min & \\
\hline
\end{tabular}

The process of data gathering in MEDCOM and ROLIND

Initially, we posted our research ideas to MEDCOM and ROLIND, and both firms indicated that they would be interested to hear more about our research. Therefore, my supervisor and I organized a workshop in each company to discuss the feasibility of conducting a research study at their premises and discuss the challenges they experienced in product developments through knowledge integration with customers. The purpose of the workshops was to present the aim of our study, gain a better understanding of the firms' strategies for collaboration with customers and knowledge integration, and identify the challenges the companies faced. During these initial workshops, we discussed all areas that would potentially benefit from our investigation.

After conducting the workshops, we received responses from MEDCOM and ROLIND, confirming that I could start the investigation on site. In preparation for the study, we discussed the selection of projects with the firms' representatives, who 
proposed product development as the most appropriate area for analysis. In light of the overall purpose of our research, it was important that we choose knowledge-intensive projects with varied customer contributions during the process. This was essential because a diverse sample would facilitate comparison across projects and potentially lead to the identification of new ideas. Access to both relevant information and people involved development projects was also an important consideration for project selection. According to these criteria, two projects were selected at each firm.

In the next stage, interviews with relevant project managers were conducted. These interviews were based on an open dialogue concerning the firm's organization, the history of the projects, and their views on the knowledge integration strategies and challenges that emerged as they involved customers in the product development process. Thereafter, I carried out a few initial interviews with key informants in each of the projects. Based on these interviews, I submitted a report that contained my initial findings, along with delineating the case studies and plans for conducting the detailed studies. Once both firms agreed with my detailed plans for the study, I conducted additional interviews with representatives from development, sales and manufacturing units. As the interviews progressed, the questions focused more on those aspects of knowledge integration that were of particular relevance to this study, including the following: (1) How do the companies integrate knowledge with their customers? (2) At what stage of the project do they typically integrate knowledge? (3) What type of responsibilities were deemed suitable for handing over to the customer? All relevant technical information and collaboration activities with customers were discussed in the interviews. The list of the interviewees, their roles, and the duration of the interviews is shown in Table 6 and Table 7. In addition to these interviews, I had frequent informal discussions with engineers and project managers during my visits to the firms, which provided additional information about the context of the projects, the essence of the collaboration with customers, and the internal challenges the firms faced. The findings and reflections from the informal discussions were continuously documented and discussed with the participants.

During the study, further meetings were planned with the project managers to discuss the issues brought up in the interviews and finalize the research findings. Based on this, I wrote a preliminary case study report for each of the projects. These were sent to all interviewees for their comments and approval. This resulted in valuable feedback, received via telephone, face-to-face meetings, or emails from eight of the interviewees. The comments and feedback from these interviewees were utilized in our final report, which consequently included the aim of the study, the theoretical background, case study findings, analysis, and practical contributions. 
Table 6. Interviews at ROLIND

\begin{tabular}{|c|c|}
\hline Title and role / responsibility & Date and length of interview \\
\hline $\begin{array}{l}\text { Head of } R \& D \text { Unit: Works in the } \mathrm{R} \& \mathrm{D} \text { unit; } \\
\text { responsible for leading the } \mathrm{R} \& \mathrm{D} \text { unit in industrial } \\
\text { marketing. }\end{array}$ & - $\quad$ June 17, 2011 (66 minutes) \\
\hline $\begin{array}{l}\text { Head of Sales Unit: Works in the sales unit; responsible } \\
\text { for determining appropriate sales strategies in whole } \\
\text { market segments. }\end{array}$ & $\begin{array}{l}\text { - } \text { October } 24,2011 \text { (86 minutes })- \\
\text { Together with Sales Application } \\
\text { Engineer }\end{array}$ \\
\hline $\begin{array}{l}\text { Mono/General Solution Factory Manager: Works in } \\
\text { the solution development unit; responsible for the } \\
\text { mapping and coordination customized solutions } \\
\text { activities for the organization and for customers. }\end{array}$ & $\begin{array}{ll}\text { - } & \text { April 18, } 2012(117 \text { minutes }) \\
\text { - } & \text { September 21, } 2012(134 \text { minutes })\end{array}$ \\
\hline $\begin{array}{l}\text { Mono Project Leader: Works in the development unit; } \\
\text { leads the Mono project and responsible for decision } \\
\text { making, planning, etc. }\end{array}$ & $\begin{array}{ll}- & \text { June } 21,2012 \text { (178 minutes }) \\
\text { - } & \text { April 17, 2012 (113 minutes }) \\
\text { - } & \text { December 5, 2012 (91 minutes })\end{array}$ \\
\hline $\begin{array}{l}\text { Mono Product Manager: Works in the development } \\
\text { unit and project owner of the Mono project; responsible } \\
\text { for driving the project to the market. }\end{array}$ & $\begin{array}{l}\text { - } \quad \text { November 4, } 2011 \text { (171 minutes)- } \\
\text { Together with Business Engineer }\end{array}$ \\
\hline $\begin{array}{l}\text { Mono Sales Application Engineer: Works in the sales } \\
\text { unit; responsible for providing knowledge-based } \\
\text { services and technical customer support. }\end{array}$ & $\begin{array}{l}\text { - } \quad \text { October 24, } 2011 \text { (86 minutes) - } \\
\text { Together with Head of Sales Unit }\end{array}$ \\
\hline $\begin{array}{l}\text { Mono Business Engineer: Works in the industrial } \\
\text { segments unit; supports the sales team in terms of } \\
\text { customer requests and demands. }\end{array}$ & 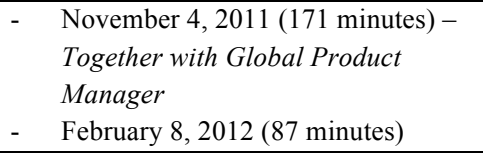 \\
\hline $\begin{array}{l}\text { Business Development Manager: Works in the } \\
\text { development unit; responsible for analyzing strategy } \\
\text { and technology planning with regard to sustainability. }\end{array}$ & $\begin{array}{ll}\text { - } & \text { June 21, } 2011 \text { (167 minutes) - } \\
\text { Together with Senior Development } \\
\text { Engineer } \\
\text { - } \quad \text { April 17, } 2012 \text { (74 minutes) }\end{array}$ \\
\hline $\begin{array}{l}\text { Senior Development Engineer: Works in the } \\
\text { development unit; support manufacturing and prepare } \\
\text { technical documents for junior engineers }\end{array}$ & 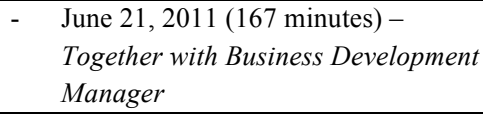 \\
\hline $\begin{array}{l}\text { Mono Key Account Manager: Works in the sales unit; } \\
\text { in charge of promoting the development unit's } \\
\text { activities among customers and aligning with customer }\end{array}$ & - $\quad$ April 25, 2012 (83 minutes) \\
\hline $\begin{array}{l}\text { Mono Development Engineer: Works in the } \\
\text { development unit; responsible for developing and } \\
\text { designing the Mono project. }\end{array}$ & - $\quad$ February 7, 2012 (96 minutes) \\
\hline $\begin{array}{l}\text { Solar Project Leader: Works in the development unit; } \\
\text { leads the Mono project and responsible for decision } \\
\text { making, planning, etc. }\end{array}$ & $\begin{array}{ll}\text { - } & \text { July 7, 2011 (61 minutes) } \\
\text { - } & \text { December 20, } 2011 \text { (115 minutes) } \\
\text { - } & \text { December 7, 2012 (102 minutes }) \\
\end{array}$ \\
\hline $\begin{array}{l}\text { Solar Sales Manager: Works in the sales unit; in charge } \\
\text { of activities related to the customer and aligning with } \\
\text { customer expectations. }\end{array}$ & - $\quad$ December 8, 2011(108 minutes) \\
\hline $\begin{array}{l}\text { Solar Technical Manager: Works in the development } \\
\text { unit; responsible for developing and design product. }\end{array}$ & - $\quad$ December 20, 2011 (112 minutes) \\
\hline $\begin{array}{l}\text { Solar Development Engineer: Works in the } \\
\text { development unit; responsible for driving the project to } \\
\text { the market and achieving market needs. }\end{array}$ & - $\quad$ December 20, 2011 (98 minutes) \\
\hline Total & 19 Interviews ( 34 hours and 25 minutes) \\
\hline
\end{tabular}


Table 7. Interviews at MEDCOM

\begin{tabular}{|c|c|}
\hline Title and role / responsibility & Date and length of interview \\
\hline $\begin{array}{l}R \& D \text { Strategy Manager: Works in R\&D units; } \\
\text { responsible for business development through } \\
\text { technical differentiation. }\end{array}$ & $\begin{array}{ll}\text { - } & \text { July 5, } 2011 \text { (117 minutes) } \\
\text { - } & \text { February 27, } 2012 \text { (121 minutes })\end{array}$ \\
\hline $\begin{array}{l}\text { Implant Sales Manager: Works in sales unit; } \\
\text { responsible for marketing and branding of the } \\
\text { project. Securing customer contractually in } \\
\text { development areas. }\end{array}$ & - June 7, 2011 (60 minutes) \\
\hline $\begin{array}{l}\text { Implant Project Manager: Works in development } \\
\text { unit; leads and evaluates the project and identifies } \\
\text { external and internal resources. }\end{array}$ & - $\quad$ June 7,2011 (117 minutes) \\
\hline $\begin{array}{l}\text { Implant Development Engineer: Works in the } \\
\text { development unit; responsible for developing and } \\
\text { testing product. Interacts with R\&D of customers. }\end{array}$ & - $\quad$ August 12, 2011 (92 minutes) \\
\hline $\begin{array}{l}\text { Implant /Fra Product Manager: Works in the } \\
\text { development unit; responsible for roadmap, strategy, } \\
\text { and features of the product. }\end{array}$ & - $\quad$ August 12, 2011 (62 minutes) \\
\hline $\begin{array}{l}\text { Fra Project Manager: Works in the development } \\
\text { unit. Leads, executes, and controls the project. }\end{array}$ & - June 10, 2011 (86 minutes) \\
\hline $\begin{array}{l}\text { Fra Sales Manager: Works in the sales unit; } \\
\text { identifies customer requirements, provides product } \\
\text { feature enhancement, and supports engineers in } \\
\text { development units. }\end{array}$ & - $\quad$ July 10, 2011 (89 minutes) \\
\hline $\begin{array}{l}\text { Fra Development Manager: Works in the } \\
\text { development unit; responsible for development team } \\
\text { and, along with sales application and sales manager, } \\
\text { communicates with customers. }\end{array}$ & - July 10, 2011 (115 minutes) \\
\hline Total & 9 Interviews (14 hours and 32 minutes) \\
\hline
\end{tabular}

Additionally, a workshop was held at the end of the study to discuss the research findings with the staff members of ROLIND, each of whom was provided with a copy of the final study report. The workshop comprised three parts. The first part focused on "Now," the current processes and issues at ROLIND. In this part, I presented the findings of the case studies and reiterated the challenges firms currently face when attempting to integrate knowledge with customers. I received valuable feedback and additional insights based on the discussion of the findings. The second part concerned the "Wow," the ideal state of knowledge integration with customers in collaborative product development. Here, we discussed what the firms wanted to achieve in the future. Finally, in the last part of the workshop, we focused on the "How," the strategies firms could use to reach their desired goals. The last part was primarily dedicated to brainstorming, with open discussion allowing different perspectives on how firms can adapt and implement the proposed approaches in order to integrate knowledge with customers. The entire case study at ROLIND took 18 months to complete, while my work at MEDCOM lasted about 9 months (see tables 8 and 9 for more details). 
Table 8. Informal activities and workshops at ROLIND

\begin{tabular}{|c|c|c|c|}
\hline Activities & Topic & Send to / Participants & Date \\
\hline $\begin{array}{l}\text { Sent a research } \\
\text { proposal to } \\
\text { ROLIND }\end{array}$ & $\begin{array}{l}\text { Description of research study on } \\
\text { knowledge integration with } \\
\text { customers }\end{array}$ & $\begin{array}{l}\text { Sent to Director of } \\
\text { Human Resources at } \\
\text { ROLIND }\end{array}$ & $\begin{array}{l}\text { February } \\
16,2011\end{array}$ \\
\hline $\begin{array}{l}\text { Telephone } \\
\text { meeting }\end{array}$ & $\begin{array}{l}\text { Communication of interest and } \\
\text { intention for the study at ROLIND } \\
\text { and set a date for the introductory } \\
\text { workshop }\end{array}$ & $\begin{array}{l}\text { Business Development } \\
\text { Manager }\end{array}$ & $\begin{array}{l}\text { February } \\
28,2011\end{array}$ \\
\hline First workshop & $\begin{array}{l}\text { Presentation of our research project } \\
\text { Understanding ROLIND's interests } \\
\text { and challenges } \\
\text { Discussion on ROLIND's overall } \\
\text { situation regarding collaboration with } \\
\text { customers }\end{array}$ & $\begin{array}{l}\text { R\&D Manager, Mono } \\
\text { Senior Project Manager, } \\
\text { Mono Global Product } \\
\text { Manager, Business } \\
\text { Development Manager, } \\
\text { Senior Development } \\
\text { Engineer, and Mono } \\
\text { Development Engineer }\end{array}$ & $\begin{array}{l}\text { March 21, } \\
2011\end{array}$ \\
\hline $\begin{array}{l}\text { Telephone } \\
\text { meeting }\end{array}$ & $\begin{array}{l}\text { ROLIND introduced Mono and } \\
\text { Solar projects to us as two case } \\
\text { studies that we could carry out } \\
\text { - } \\
\text { Planned the research study at } \\
\text { ROLIND }\end{array}$ & $\begin{array}{l}\text { Mono Senior Project } \\
\text { Manager and Business } \\
\text { Development Manager }\end{array}$ & $\begin{array}{l}\text { April 19, } \\
2011\end{array}$ \\
\hline $\begin{array}{l}\text { Sent a research } \\
\text { plan report }\end{array}$ & $\begin{array}{l}\text { - Identifying who needs to be } \\
\text { interviewed and discussing the } \\
\text { preliminary timeline }\end{array}$ & $\begin{array}{l}\text { Mono Senior Project } \\
\text { Manager and Business } \\
\text { Development Manager }\end{array}$ & $\begin{array}{l}\text { May 4, } \\
2011\end{array}$ \\
\hline $\begin{array}{l}\text { Sent } \\
\text { preliminary } \\
\text { findings report }\end{array}$ & $\begin{array}{l}\text { After conducting four interviews } \\
\text { with key interviewees, we } \\
\text { submitted a report that contained } \\
\text { a summary and overall } \\
\text { assessment of the case studies, } \\
\text { the initial findings, and a further } \\
\text { detailed study plan. }\end{array}$ & $\begin{array}{l}\text { Head of R\&D Manager, } \\
\text { Senior Project Leaders } \\
\text { (Mono and Solar), } \\
\text { Senior Development } \\
\text { Engineer and Business } \\
\text { Development Manager }\end{array}$ & $\begin{array}{l}\text { September } \\
1,2011\end{array}$ \\
\hline $\begin{array}{l}\text { Informal } \\
\text { meetings (face- } \\
\text { to-face and } \\
\text { telephone } \\
\text { meetings) }\end{array}$ & 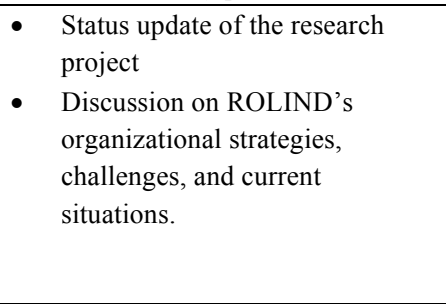 & $\begin{array}{l}\text { Business Development } \\
\text { Manager, Mono Senior } \\
\text { Project Leader, Mono } \\
\text { Solution Factory } \\
\text { Manager, Mono Global } \\
\text { Product Manager, } \\
\text { Portfolio Manager, Solar } \\
\text { Project Leader }\end{array}$ & $\begin{array}{l}\text { November4, } \\
2011 ; \\
\text { December } \\
20,2011 ; \\
\text { February } 7 \\
\text { and } 20 \text {, } \\
2012\end{array}$ \\
\hline $\begin{array}{l}\text { Sent a } \\
\text { preliminary } \\
\text { version of } \\
\text { Papers } 1 \text { and } 2\end{array}$ & $\begin{array}{l}\text { Received ROLIND's feedback } \\
\text { and comments on our empirical } \\
\text { findings. }\end{array}$ & $\begin{array}{l}\text { Business Development } \\
\text { Manager }\end{array}$ & $\begin{array}{l}\text { February } \\
\text { and June }\end{array}$ \\
\hline $\begin{array}{l}\text { Sent a } \\
\text { preliminary } \\
\text { version of the } \\
\text { final case study } \\
\text { report }\end{array}$ & $\begin{array}{l}\text { After conducting all the interviews, } \\
\text { we submitted a preliminary version } \\
\text { of the final case study report and } \\
\text { discussed the following: }\end{array}$ & All the interviewees & $\begin{array}{l}\text { June 18, } \\
2012\end{array}$ \\
\hline
\end{tabular}




\begin{tabular}{|c|c|c|c|}
\hline & $\begin{array}{l}\text { - } \quad \text { The overall background of our } \\
\text { study } \\
\text { - } \quad \text { The process of our study } \\
\text { - } \quad \text { Case study findings } \\
\text { - } \quad \text { Recommendations for } \\
\text { knowledge integration with } \\
\text { customers }\end{array}$ & & \\
\hline $\begin{array}{l}\text { Telephone and } \\
\text { email }\end{array}$ & $\begin{array}{l}\text { - } \\
\text { feeceived comments and } \\
\text { reports and discussed the } \\
\text { suggested improvements }\end{array}$ & $\begin{array}{l}\text { R\&D Manager, Mono } \\
\text { Solution Factory } \\
\text { Manager, Mono Senior } \\
\text { Project Manager, Mono } \\
\text { Sales Application } \\
\text { Engineer, Business } \\
\text { Development Engineer, } \\
\text { Mono Global Product } \\
\text { Manager, Solar Project } \\
\text { Leader }\end{array}$ & $\begin{array}{l}\text { August } \\
2012\end{array}$ \\
\hline $\begin{array}{l}\text { Sent a final } \\
\text { case study } \\
\text { report }\end{array}$ & $\begin{array}{l}\text { After receiving the comments and } \\
\text { feedback from most of the } \\
\text { interviewees, we revised the report } \\
\text { and included the following points in } \\
\text { our final research study report: } \\
\text { The aim of the study } \\
\text { Method } \\
\text { Theoretical background } \\
\text { Case study findings } \\
\text { Analysis of our findings } \\
\text { Practical contribution }\end{array}$ & To all the interviewees & $\begin{array}{l}\text { September } \\
17,2012\end{array}$ \\
\hline $\begin{array}{l}\text { Final } \\
\text { workshop }\end{array}$ & $\begin{array}{ll}\text { - } & \text { Presented our findings } \\
\text { - } & \text { Discussed our recommendations } \\
\text { - } & \text { Shared and discussed ROLIND's } \\
\text { thoughts, considerations, and } \\
\text { concerns } \\
\text { - } \\
\begin{array}{l}\text { Discussed ROLIND's future } \\
\text { plans }\end{array}\end{array}$ & $\begin{array}{l}\text { R\&D Manager, Mono } \\
\text { Senior Project Manager, } \\
\text { Solar Project Leader, } \\
\text { Mono Global Product } \\
\text { Manager, Business } \\
\text { Development Manager, } \\
\text { Senior Development } \\
\text { Engineer, Mono } \\
\text { Development Engineer, } \\
\text { Mono Solution Factory } \\
\text { Manager }\end{array}$ & $\begin{array}{l}\text { December } \\
14,2012\end{array}$ \\
\hline
\end{tabular}


Table 9. Informal activities and workshops at MEDCOM

\begin{tabular}{|c|c|c|c|}
\hline Activities & Topic & Send to / Participants & Date \\
\hline $\begin{array}{l}\text { Sent } \\
\text { research } \\
\text { proposal to } \\
\text { ROLIND }\end{array}$ & $\begin{array}{l}\text { Description of research study on } \\
\text { knowledge integration with customers }\end{array}$ & $\begin{array}{l}\text { Head of Product Area } \\
\text { and R\&D Strategy } \\
\text { Manager }\end{array}$ & $\begin{array}{l}\text { March 9, } \\
2011\end{array}$ \\
\hline $\begin{array}{l}\text { Telephone } \\
\text { meeting }\end{array}$ & $\begin{array}{l}\text { Informed our interest and intention } \\
\text { regarding the study at MEDCOM and } \\
\text { set a date for introductory workshop }\end{array}$ & Head of Product Area & $\begin{array}{l}\text { March 11, } \\
2011\end{array}$ \\
\hline $\begin{array}{l}\text { First } \\
\text { workshop }\end{array}$ & $\begin{array}{l}\text { Presentation of our research project } \\
\text { Understanding MEDCOM's interests } \\
\text { and challenges } \\
\text { Discussing MEDCOM overall situation } \\
\text { towards collaboration with customers }\end{array}$ & $\begin{array}{l}\text { Head of Product Area } \\
\text { and R\&D Strategy } \\
\text { Manager }\end{array}$ & April 5, 2011 \\
\hline $\begin{array}{l}\text { Sent a } \\
\text { research } \\
\text { plan report }\end{array}$ & $\begin{array}{l}\text { Identifying who needs to be interviewed } \\
\text { and discussing the preliminary timeline }\end{array}$ & $\begin{array}{l}\text { Mono Senior Project } \\
\text { Manager and Business } \\
\text { Development Manager }\end{array}$ & May 4, 2011 \\
\hline $\begin{array}{l}\text { Telephone } \\
\text { meeting and } \\
\text { email }\end{array}$ & $\begin{array}{l}\text { MEDCOM introduced Implant and } \\
\text { FRA projects to us as two case } \\
\text { studies that we could carry out } \\
\text { - Plan the research study at } \\
\text { MEDCOM }\end{array}$ & R\&D Strategy Manager & May 9, 2011 \\
\hline $\begin{array}{l}\text { Informal } \\
\text { meetings } \\
\text { (face to face } \\
\text { and } \\
\text { telephone } \\
\text { meeting) }\end{array}$ & $\begin{array}{l}\text { Status update of the research } \\
\text { project } \\
\text { Discussion on MEDCOM's } \\
\text { organizational strategies, } \\
\text { challenges, and current situation. }\end{array}$ & R\&D Strategy Manager & June 10,2011 \\
\hline $\begin{array}{l}\text { Sent } \\
\text { preliminary } \\
\text { findings } \\
\text { report }\end{array}$ & $\begin{array}{l}\text { After conducting four interviews } \\
\text { with key interviewees, we } \\
\text { submitted a report that contained a } \\
\text { summary and overall assessment of } \\
\text { the case studies, the initial findings, } \\
\text { and a further detailed study plan. }\end{array}$ & All the interviews & $\begin{array}{l}\text { September 1, } \\
2011\end{array}$ \\
\hline $\begin{array}{l}\text { Telephone } \\
\text { and email }\end{array}$ & $\begin{array}{l}\text { Received comments and feedback } \\
\text { on our preliminary reports and } \\
\text { discussed the suggested } \\
\text { improvements }\end{array}$ & $\begin{array}{l}\text { R\&D Strategy Manager } \\
\text { and Implant Project } \\
\text { Leader }\end{array}$ & $\begin{array}{l}\text { September } \\
2012\end{array}$ \\
\hline $\begin{array}{l}\text { Sent a } \\
\text { preliminary } \\
\text { version of } \\
\text { the Paper } 1\end{array}$ & $\begin{array}{l}\text { Received ROLIND's feedback and } \\
\text { comments on our empirical } \\
\text { findings }\end{array}$ & R\&D Strategy Manager & $\begin{array}{l}\text { February } 28, \\
2012\end{array}$ \\
\hline
\end{tabular}

The process of data gathering in Elekta

Data for the Elekta study were gathered during my master thesis project. Together with a colleague student, I spent roughly nine months at the company, located on site at its R\&D Management office in Stockholm. I also visited its purchasing and manufacturing operations offices regularly. I had the opportunity to observe the events and actions at 
these units during the time I spent with the company. Altogether, the study is based on 18 formal interviews, many informal discussions, a collection of related documents, and other relevant activities.

The first phase of the study lasted about two months and focused on understanding the firm and delivering the two projects assigned to the researchers (one of which is the topic of this thesis). I was stationed at the office with all other employees, who were aware of my presence. Elekta employees initiated several informal discussions during lunch breaks and social outings after work. These occasions offered an opportunity to establish good relationships with the employees, which in turn helped me to better understand the key features of the firm, including its organization, procedures, and practices. I also received various documents explaining the background status and scope of the project, and met with the project manager of the Muse project to discuss its status during the first phase of the study.

In the second phase of the study, which lasted about five months, I carried out detailed interviews. Respondents were chosen among key employees in the development department, as well as manufacturing, purchasing, and R\&D departments. These interviews facilitated the formulation of specific research questions, one of them concerning the internal functions related to Elekta's collaborative relationships with suppliers. In particular, there were two instances where project managers, purchasing engineers, and manufacturing managers and engineers had an internal meeting to update one another before integrating suppliers, which helped the researchers to find some of the internal challenges that suppliers might face in their collaboration with Elekta. Subsequently, I interviewed the suppliers of Elekta to consider their opinions as well. Five different suppliers who participated in the studied projects were interviewed.

The third and final period lasted about two months. During this period, I presented the findings in several meetings with Elekta. Two reports were written and provided to all the interviewees, and the researchers carried out face-to-face meetings with them to understand their concerns better. Subsequently, final recommendations were presented in a seminar with more than 30 respondents present.

\subsubsection{Case study data analysis}

Although figure 1 implies a sequential process for the purpose of simplicity, the data analysis was performed more as an iterative process of going back and forth between the literature and the empirical data. At the start of the empirical analysis, I reviewed the general theoretical framework on knowledge integration and customer collaboration. In parallel, for each case study, I wrote a case description. Through this process, I reviewed relevant literature, which allowed me to compare the literature with the description of each case. This strategy is also proposed by Eisenhardt (1989), who 
has suggested that researchers need to work in a systematic way to compare empirical data with theory through an iterative process. During the comparison, I focused on literature sources that specifically addressed customer collaboration, customer roles, and knowledge integration mechanisms. These revealed how firms manage knowledge integration with customers in collaborative product development.

The case study analysis enhances the understanding of different circumstances of the phenomenon studied and explains why such differences exist. The collected data were organized, categorized, and coded to allow a systematic analysis for the case studies. In this thesis, the data gathered through interviews were subjected to a detailed analysis that took the interviewees' understanding of the projects into consideration. The analysis approach is discussed in detail in the next section.

\section{Content analysis and categories}

The data relevant to each case study was systematically collected, categorized, and coded to facilitate further analysis. This commenced with transcribing the interviews and reviewing the transcripts in order to identify categories corresponding to those included in the theoretical framework. Yin (2009) referred to this analytic technique as pattern matching, noting that it allows the researcher to compare the anticipated patterns with the empirical findings. For example, regarding the case studies described in Paper 1 , we started the coding with broad and general categories such as "customer roles". Once different customer roles were identified, the aim was to evaluate customer knowledge contribution. Throughout this process, the initial propositions about the roles of customers and possible knowledge contributions were reviewed by adding and removing other codes and categories. Understanding the roles that customers could assume in development projects appeared to be essential for knowledge contribution by customers. However, from a review of additional literature on this topic, followed by further interpretation of the collected data and case description, other categories such as timing of contribution and contextual factors emerged. Therefore, adding these new categories/codes, such as contextual factors, to the analysis, allowed us to investigate how customer roles can be expressed in terms of timing and content of knowledge contribution. Examples of codes/categories and identified units in the first empirical paper (related to only one of the customer roles) are shown in table 10. 
Table 10. Example of codes/categories in the first empirical study

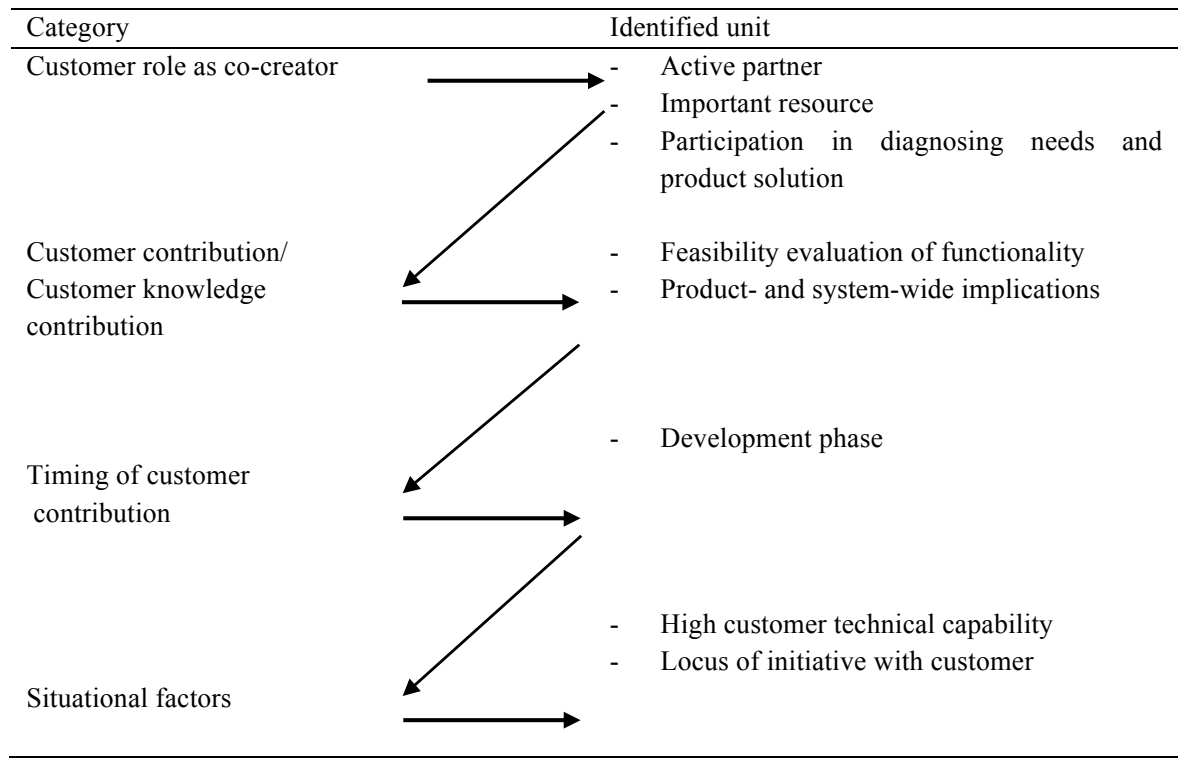

Similarly, in the second empirical paper, the case description was coded into the categories of customer contribution and knowledge integration mechanisms through pattern matching. Broad categories were predetermined according to the theoretical framework, with additional codes emerging as we progressed through the data analysis. For instance, different knowledge integration activities and customer knowledge contributions were added to the analysis based on the emergent themes such as practices. In addition, the data indicated that knowledge integration mechanisms and content of customer knowledge evolve during consecutive phases of product development. This motivated me to analyze the mechanisms and practices by phase of project development (see table 11). 
Table 11. Example of codes/categories in the second empirical study

\begin{tabular}{ll}
\hline Category/code & Identified unit \\
\hline Category & - Group problem solving \\
Knowledge integration \\
mechanism
\end{tabular}

In the third empirical paper, the approach used in the second one was adopted. This allowed me to add codes in a dialectical relationship between empirical data and predicted patterns (Yin, 2009). This strategy also facilitated a comparison between theory and data in an iterative manner (Eisenhardt, 1989). Yin (2009) argued that this "abductive reasoning" aims to create theoretical replication.

\section{Within-case and cross-case analysis}

Many researchers have discussed within-case analysis, which includes detailed case write-ups (Ayres et al., 2003). The gathered data were carefully investigated and subsequently classified into different groups according to their differences and similarities. In addition, cross-case analysis of all case studies was performed, as it assisted in gaining valuable theoretical insights that could be used when formulating the study's conclusions (Bryman, 2008). In order to avoid the risk of being overwhelmed by a large number of variables in a comparative analysis, the focus should only be on key variables (Lijphart, 1971). Thus, to facilitate the comparison, phases were analyzed, depending on some factors and the process of knowledge integration with customers. Similarities and differences between cases were identified according to categories and dimensions and the process of knowledge integration.

\subsubsection{Validity and reliability}

\section{Construct validity}

Construct validity is achieved by establishing correct operational measures for the theoretical constructs being studied (Yin, 2009). As operationalizing measures is often challenging, Brown and Eisenhardt (1995) suggested operationalizing the key concepts at the start of the investigation to prevent the use of poorly constructed measures. This initial theoretical framework can thus guide the establishment of measures employed in the investigation. Therefore, the theoretical framework adopted in the present study guided the construction of measures to reduce the effect of inadequacy. Hence, defining 
and operationalizing the key concept(s) in the beginning of the research process were crucial. Knowledge integration was one of the key concepts for which pertinent literature was used effectively to formulate valid and appropriate measures. A literature review also revealed the existence of two streams of research, one of which emphasized knowledge integration as a process where individuals share and combine knowledge. In addition, in the second stream, the capability of the organization to access knowledge was deemed the most important. In order to develop valid measures, several discussions were held with researchers within the field (Table 12).

Table 12. Constructs for knowledge integration

\begin{tabular}{ll}
\hline Constructs & Measures/Indicators \\
\hline $\begin{array}{l}\text { Knowledge integration as process } \\
\text { (e.g., Huang and Newell, 2003; Okhyusen and }\end{array}$ & $\begin{array}{l}\text { Meeting, interactive discussion, Joint problem } \\
\text { solving to share and combine knowledge }\end{array}$ \\
Eisenhardt, 2002; Tiwana and McLeand, 2005) & \\
\hline $\begin{array}{l}\text { Knowledge integration as capability } \\
\text { (e.g., Lin and Chen, 2006; Subramaniam and }\end{array}$ & $\begin{array}{l}\text { Access partner's knowledge, Synergy created, } \\
\text { creating new business opportunity }\end{array}$ \\
Soh, 2006) & \\
\hline
\end{tabular}

In addition, to ensure construct validity during the process of data collection, it was essential to use multiple resources when gathering data. Data triangulation allows viewing the phenomenon from different perspectives, provided by multiple sources (Eisenhardt, 1989). In this thesis, data triangulation was achieved through interviews, feedback provided by the interviewees upon reviewing the case study report, workshops held at the companies, and analyses of project documents and technical specifications. Additionally, construct validity was discussed in various instances. At the university, the supervisors and a colleague from the same project gave their highly valuable inputs on the case study report, in which the collected data were presented. Furthermore, all the key informants from the participating companies were invited to review the drafts and provide their comments. Three case study reports were sent to all the participating firms on three occasions to give them the opportunity to review, clarify, and comment on the initial data interpretation. Through informal discussions, workshops, and visits to the firms, the validity of the study findings and their practical relevance was improved (Creswell, 2009).

\section{Internal validity}

Internal validity is the degree to which conclusions can be drawn correctly from the study findings. It is ensured by identifying links between the observations and the idea that was developed based on their analysis (Bryman, 2008). In particular, researchers have to ascertain whether changes in a certain variable are affected by another variable, or there are alternative explanations for the observed changes. In the present study, several measures such as pattern matching were used to ensure internal validity. Pattern matching was employed when comparing empirical patterns with the predicted ones to strengthen the internal validity. For instance, one of the predictions was that customer 
capability and the commitment of actors could influence customer collaboration and, in turn, customer knowledge contribution. Finding congruence between the patterns of customer collaboration and customer knowledge contribution in the studied cases strengthened the internal validity. However, emergent patterns were not neglected during the case studies. For instance, some patterns regarding the dynamics of knowledge integration with customers throughout the development process emerged and were discussed during the study.

\section{External validity}

Yin (2003) noted that external validity is achieved by "establishing the domain to which a study's findings can be generalized" (p. 34). External validity refers to the potential for the study findings to be generalizable to other research fields. According to Yin (2003), while generalization from case studies to broader practical settings is usually limited, generalization to theory is possible. Hence, in the case study part of this research, the aim was not to generalize the findings to other contexts; however, the potential to contribute to the theory was explored. Moreover, the case study approach in this study was adopted as the aim was to obtain in-depth understanding of a specific phenomenon in a certain condition, rather than generalize to all possible units (Merriam, 1998). However, the generated theory was subsequently tested by employing the survey approach, discussed later in this thesis.

\section{Reliability}

Reliability is defined by Yin (2003) as "demonstrating that the operations of a study such as data collection procedures - can be repeated with the same results" (p. 34). The purpose of reliability "is to minimize errors and biases in the research" (p. 37). In this thesis, reliability was guaranteed by following an interview guide and evolving a case study database for systematic documentation. The case study database contains raw data material, interview transcripts, recorded interviews, project documents, tables, and case write-ups, which allow other researchers to study the evidence directly. The database was formed during the research process. Table 13 presents the validity and reliability tests, as well as the strategies and techniques that have been used in the case studies. 
Table 13. Tactics used for promoting validity and reliability

\begin{tabular}{ll}
\hline Test & Tactics \\
\hline Construct validity & Data triangulation \\
& Study report to companies \\
& Discussion with colleagues \\
& Receiving feedback from respondents in the firms \\
\hline Internal validity & Pattern matching \\
\hline External validity & Analytical generalization \\
& \\
\hline Reliability & Interview guide \\
& Case study database \\
& $\circ$ Raw data material \\
& $\circ$ Interview transcripts \\
& $\circ$ Project documents \\
& $\circ$ Case write-up \\
\hline
\end{tabular}

\subsection{Survey study approach}

A survey approach can ensure data integrity, while introducing analytical measurement error due to a limited number of analytical variables (Bonoma, 1985). Therefore, the use of both approaches is ideal (Bryman and Bell, 2007). This was the strategy employed in the present study, whereby case studies were complemented by a survey. Empirical evidence indicates that using a combination of approaches is reliable for answering research questions in a study focusing on a complex phenomenon (Brewer and Hunter, 2006). Consequently, in this work, a survey study approach was used to test the results found in the case studies and identified in the existing literature. In this respect, a survey of Swedish manufacturing firms that collaborate with customers was carried out. When designing the questionnaire, the case study results and an overview of the pertinent literature were reconsidered. This resulted in identifying 10 variables related to customer collaboration in product development, namely, knowledge integration, customer involvement, customer technical capability, firm technical capability, locus of initiative, innovation performance, absorptive capacity, technological uncertainty, product uncertainty, and firm strategy. This thesis project, which comprises Papers 4 and 5, uses only a subset of these variables. This is seen as a limitation of this study, which will be addressed in a future analysis with the adoption of additional variables.

Given that the main goal of any research study is to expand the existing knowledge and meaningfully contribute to the field, and that the currently available information relevant to knowledge integration and customer collaboration is insufficient, the available literature must be continually reviewed for the identification of the most appropriate constructs for each variable. The literature review commenced with an investigation of 134 articles, 70 of which were subsequently summarized in an Excel 
file and examined for questionnaire preparation. The survey questions pertaining to each variable are listed in the appendix.

Comments and feedback on the questionnaire structure and content were received from several practitioners (R\&D managers of ROLIND and MEDCOM) and two senior researchers in the field who participated in the pilot study. The questionnaire was revised based on the comments and feedback received, and the final version was translated to the Swedish language. To ensure accuracy, two native Swedish speakers were asked to translate the questionnaire content back to English.

\subsubsection{Sample selection and data collection}

The research sample was selected from a survey of the Swedish manufacturing industry. The population of interest for this investigation included manufacturing firms (codes 10-32 in NACE Rev.2) employing at least 50 staff. Data collection was based on a randomized representative sample of 700 manufacturing firms drawn from the targeted population.

The survey using the questionnaire described above was conducted during the spring of 2015 by the author of this thesis and two project assistants. The respondents were mainly R\&D managers or development managers employed in the sample firms. The overall time to answer the survey was about 20 to 30 minutes. At the start of the data collection process, each potential study participant was contacted by phone and was informed about the content and the purpose of the study. They were also informed about the nature of their participation and, if the respondent could not participate in the survey (e.g., due to low interest or heavy workload), were asked to suggest another person who could offer insights of value for the study. Among the 700 individuals contacted in this manner, 350 expressed interest and provided their email addresses. They were reassured that their personal information and the company name would remain anonymous and their responses would only be reported in an aggregated form. The survey questionnaire was subsequently mailed to each respondent and was accompanied by a cover letter that further explained the purpose and motivation of the study. All respondents were provided four weeks to respond. Thereafter, the first reminders were sent and, if required, a second reminder was issued four weeks later. This approach resulted in 216 usable surveys, confirming the effectiveness of the data collection strategy as well as participants' appreciation of the study and its objectives.

\subsubsection{Measurement}

All dependent and independent variables were based on five-point Likert-type scales, ranging from 1 (strongly disagree) to 5 (strongly agree), which ensured statistical variability across the survey responses. 
In Paper 4, the dependent variable, innovation performance, was a factor score assessed on items related innovation risks, introducing new products and services, product development cost, time-to-market, and opening of a new market (Lazzarotti and Manzini, 2009; Bengtsson et al., 2013). The independent variable representing knowledge integration is measured according to six items adopted from Tiwana (2008) and Akgun et al. (2007): discussing errors and failures with customers, (2) discussing new ideas and activities with customers, (3) developing new concepts together with customers, (4) discussions spanning several areas of expertise, (5) synthesizing and integrating individual expertise (by two parties), and (6) blending new project-related knowledge with what they already know. The degree of customer collaboration (involvement) was captured by asking to what extent the firm collaborated with customers in the following product development phases: ideation, concept, development, and commercialization. The items for this construct was captured from Ritter and Walter (2003).

In Paper 5, knowledge integration was considered as the dependent variable with the same items mentioned above, derived from Tiwana (2008) and Akgun et al. (2007). The first and second independent variables, related to firm's and customer's technical capability, were measured via seven items, namely, engineer's proficiency with the latest technology, engineer's technological innovation skills, capability of incorporating external technology into new product, offering engineer support, and responding quickly to technological changes (LaBahn and Krapfel, 2000). The third independent variable, locus of initiative at the firm side, was based on three items: involving customers in the development and construction phase, asking customers for their views on product prototypes during new product development, and involving customers in determining the new product configuration (Feng et al., 2010). Similarly, the fourth independent variable, locus of initiative at the customer side, was measured by two items, customers' present ideas and suggestions for new product function, and customers' present ideas and suggestions for new materials used in creating products (Svensen et al., 2011).

In both Papers 4 and 5, additional control variables (i.e., technological uncertainty, product uncertainty, firm size, and turnover of the participating firms) were included. Technological uncertainty was determined as a factor score based on the following items: high level of technological innovation in the industry, more complex products in the industry, rapidly changing technology in the industry, big opportunities in the industry through technological change (Song and Weiss, 2001; Ragatz et al., 2002). Product uncertainty is assessed by items related to complexity, degree of innovation, products with engineering content, and products based on rapidly changing technologies. This approach is adapted from Yan and Dooley (2013). 


\subsubsection{Survey data analysis}

The responses are codified through descriptive statistics, frequency tables, and illustration graphs. T-tests were used to check the possibility of non-response bias. Factor loading was also employed to assess the composite reliability. In addition, in order to test the hypotheses that were examined in the survey study, hierarchical regression method was used. The hierarchical regression method is an appropriate technique to assess contextual and configuration models. In the hierarchical regression methods, different variables are added sequentially and the models are compared to test if successive models fit the previous one better. Thus, it can be established whether a higher-order model accounts for a statistically significant improvement in the explained variance, indicated by an R-square change (Wiklund and Shepherd, 2005)

In order to evaluate the reliability of the survey, we tested the internal consistency. To do so, we checked the loading of each indicator used to measure the constructs that were beyond the suggested 0.7 acceptance cut-off value. To assess construct validity, we used the established scales, sourced from the literature. Additionally, we performed pre-testing on the scales with the help of senior researchers in academia and some industry practitioners. This led to some minor changes and helped us to paraphrase and revise some of the questions, which they deemed inappropriate for capturing the constructs as intended. In addition to evaluating the accuracy of the measurement, the prior case studies helped us to further enhance the construct validity of our survey. This was possible because the previous case studies provided practical knowledge on the research context, such as knowledge integration and customer collaboration. By evaluating the case studies, we were able to operationalize the constructs in a better way, particularly using the interviews to select among the items.

\subsection{Presenting the material in papers and authorship}

Paper 1 compares the Mono, Solar, Implant, and Fra cases. Paper 2 is based on a single case study. Paper 3 includes the Muse project and compares the subprojects. Papers 4 and 5 are based in the survey study and include different dependent and independent variables (see Table 14).

Table 14. Mapping papers

\begin{tabular}{|c|c|c|c|}
\hline Papers & Firms & Project & Survey \\
\hline Paper 1 & $\begin{array}{l}\text { MEDCOM \& } \\
\text { ROLIND }\end{array}$ & $\begin{array}{l}\text { Implant, Fra, Mono, } \\
\text { and Solar }\end{array}$ & - \\
\hline Paper 2 & ROLIND & Mono & - \\
\hline Paper 3 & Elekta & Muse & - \\
\hline Paper 4 & - & - & $\begin{array}{l}\text { Swedish } \\
\text { manufacturing firms }\end{array}$ \\
\hline Paper 5 & - & - & $\begin{array}{l}\text { Swedish } \\
\text { manufacturing firms }\end{array}$ \\
\hline
\end{tabular}


As the first author of all five papers, I not only conducted data collection but also performed both initial and follow-up data analysis, the latter in collaboration with my co-authors. Thus, I was mainly responsible for writing all the papers and performing all data analysis. Nicolette Lakemond, as the main supervisor of this thesis, co-authored all the papers. She provided extensive help and support in developing this paper. Her insightful contribution extended to literature review, positioning of the articles, developing the analysis, and synthesizing the findings. The third paper was co-authored by Stefano Brusoni, another supervisor. He supported me during the empirical study and data analysis, and in developing the third paper (see Table 15).

Table 15. Authorship and publication

\begin{tabular}{|c|c|c|c|}
\hline Paper & Title & Co-author (s) & Status \\
\hline 1 & $\begin{array}{l}\text { Knowledge integration in } \\
\text { collaborative product } \\
\text { development process }\end{array}$ & $\begin{array}{l}\text { Nicolette } \\
\text { Lakemond }\end{array}$ & $\begin{array}{l}\text { Published in the Journal of Business \& } \\
\text { Industrial Marketing } \\
\text { Earlier version presented at the } \\
\text { EUROMA Conference, Amsterdam, } \\
2012\end{array}$ \\
\hline 2 & $\begin{array}{l}\text { Knowledge integration in } \\
\text { complex systems } \\
\text { development: What do } \\
\text { suppliers actually do to } \\
\text { integrate knowledge with } \\
\text { customers? }\end{array}$ & $\begin{array}{l}\text { Nicolette } \\
\text { Lakemond \& } \\
\text { Stefano Brusoni }\end{array}$ & $\begin{array}{l}\text { Submitted to a scientific journal, } \\
\text { received major revision in November } \\
2016 \\
\text { Earlier version presented at the IPDM } \\
\text { Conference, Paris, } 2013\end{array}$ \\
\hline 3 & $\begin{array}{l}\text { Internal integration in } \\
\text { complex collaborative } \\
\text { product development projects }\end{array}$ & $\begin{array}{l}\text { Nicolette } \\
\text { Lakemond }\end{array}$ & $\begin{array}{l}\text { Published in the International Journal } \\
\text { of Innovation Management } \\
\text { Earlier version presented at the R\&D } \\
\text { Management Conference, Norrköping, } \\
2011 .\end{array}$ \\
\hline 4 & $\begin{array}{l}\text { Knowledge integration with } \\
\text { customers in innovation: } \\
\text { Empirical evidence from } \\
\text { Swedish manufacturing firms }\end{array}$ & $\begin{array}{l}\text { Nicolette } \\
\text { Lakemond }\end{array}$ & $\begin{array}{l}\text { Working paper to be submitted to a } \\
\text { scientific journal } \\
\text { Earlier version presented at the CINet } \\
\text { Conference, Stockholm, } 2015\end{array}$ \\
\hline 5 & $\begin{array}{l}\text { The role of technical } \\
\text { capabilities and locus of } \\
\text { initiative for knowledge } \\
\text { integration with customers in } \\
\text { collaborative product } \\
\text { development }\end{array}$ & $\begin{array}{l}\text { Nicolette } \\
\text { Lakemond }\end{array}$ & $\begin{array}{l}\text { Working paper to be submitted to a } \\
\text { scientific journal } \\
\text { Earlier version accepted at the IMP } \\
\text { Conference, Poznan, } 2016\end{array}$ \\
\hline
\end{tabular}




\section{Summary of the papers}

This chapter summarizes the most important results from the five appended papers concerning the comprehensive analysis of knowledge integration with customers in collaborative product development projects. All five papers are related to the purpose and research questions of this thesis. In addition, it is important to note that, as stated in chapter one of this thesis, product development activities reside at the focal firms, i.e., manufacturing firms that supply products and systems to their customers. In this thesis and in the paper, we sometimes refer to these as (manufacturing) firms and sometimes as suppliers. However, we call them firms in this chapter to avoid confusing the reader. Consequently, we refer to firms as suppliers of products and systems and as actors who undertake product development activities and to their customers as actors who (potentially) buy their products. Table 16 provides an overview of the appended papers in relation to the study objectives, the research methods, and the relationships between the aforementioned papers and research questions.

Table 16. Overview of papers

\begin{tabular}{llll}
\hline Paper & Method & Focus & $\begin{array}{l}\text { Research question } \\
\text { addressed }\end{array}$ \\
\hline I & Case study & $\begin{array}{l}\text { Customer knowledge contribution and } \\
\text { timing of customer collaboration }\end{array}$ & RQ1, RQ2 \\
\hline II & Case study & $\begin{array}{l}\text { Mechanisms of knowledge integration } \\
\text { with customers }\end{array}$ & RQ 1 \\
\hline III & Case study & $\begin{array}{l}\text { Internal integration in collaborative } \\
\text { product development }\end{array}$ & RQ 2 \\
\hline IV & Survey study & $\begin{array}{l}\text { Effect of knowledge integration on } \\
\text { innovation performance }\end{array}$ & RQ 3 \\
\hline V & Survey study & $\begin{array}{l}\text { The effect of situational factors on } \\
\text { knowledge integration with customers }\end{array}$ & RQ2 \\
\hline
\end{tabular}

\subsection{Paper 1 \\ Knowledge integration with customers in collaborative product development projects}

\subsubsection{Summary}

Paper 1 has almost the same title as the complete doctoral thesis and aims to provide an in-depth insight into the integration of the customer's knowledge in the (supplier) firm's product development projects. Based on an analysis of knowledge integration with customers at the project level, it offers insights into the customer's knowledge contribution and the timing of customer collaboration in the phases of the product development process. The empirical results in the paper are based on a multiple-casestudy approach focusing on four product development projects at two large firms, ROLIND and MEDCOM. 
A detailed analysis of the four cases in the paper reveals that a customer's knowledge contribution changes during the different phases of collaborative product development projects. For instance, in one of the cases, namely, the Mono project, knowledge integration activities with the customer were extensive, and took place continuously throughout the product development process. Compared to the Mono project, knowledge integration with the customers in the other product development projects was more limited. For instance, the case studies of two of the other projects, namely, Solar and Implant, reveal that the customer's activities tended to occur mainly in the early and late phases of the development project. In the fourth project, namely, the Fra project, knowledge integration with the customer was limited to the early phase of the product development process, where it specifically focused on obtaining the technical specifications for the product.

The findings from the four cases expose that customers can have different roles in development processes, depending on their knowledge contribution and the timing of customer collaboration. In addition, the empirical study identifies two important contextual factors: the customer's technical capability and the locus of initiative. The results indicate that these seem to influence the customer's knowledge contribution and the timing of collaboration. Based on these results, the paper suggests a typology of knowledge integration with customers by determining different approaches. One approach to knowledge integration with customers is to involve a customer during all phases of the development process. The customer thus assumes the role of co-creator. The empirical results imply that the customer's level of technical capability and the locus of initiative for the project are two important prerequisites for a customer to act as a co-creator. In the second approach, knowledge integration with customers does not take place in all the project phases. Instead, it is restricted to the ideation and testing phases of the development process. In this situation, the customer has a less-intense role and acts either as a user or a resource. The role of a user suggests that either the locus of initiative resides at the firm or the customer has a technical capability that is critical for the project. In the third situation, knowledge integration with customers is confined to the ideation phase of the product development process. In this case, customer involvement focuses on resource and knowledge integration based on a transactional relationship (Lagrosen, 2005) that aims to attain the required product specifications.

\subsubsection{My contribution to the paper}

Paper 1 is co-authored with Nicolette Lakemond. I collected data for the paper at the two Swedish manufacturing firms and conducted the initial analysis. I wrote the first version of the paper, and throughout the writing, Nicolette Lakemond offered valuable comments and helped to develop the analysis. 


\subsection{Paper 2 \\ Knowledge integration in complex system development: what suppliers actually do to integrate knowledge with customers?}

\subsubsection{Summary}

In Paper 2, we set out to study the processes and mechanisms of knowledge integration in more detail. The aims of the paper are twofold: (1) to provide insight into the dynamics of knowledge integration in different phases and (2) to identify what suppliers actually do to integrate knowledge with customers in the complex product development process.

These aims were met through a single detailed case study. The case study focuses on one project, i.e., the Mono project, and allowed us to analyze knowledge integration with customers in detail. The firm is called Alpha in the paper, but is referred to as ROLIND in other parts of the thesis. The Mono project focuses on the development of a complex system, based on multiple technologies that provide functionality and monitoring capability for the customer's manufacturing system. This solution developed in the Mono project is specifically attractive for manufacturing plants where there may be high risks or tough conditions in the production processes. The in-depth study of the Mono project allowed investigating how the integration of knowledge evolves through the phases of the development process. The analysis is based on three aspects of knowledge integration: (1) the knowledge content (or knowledge contribution), (2) the mechanisms used for knowledge integration, and (3) the involved actors' perspectives on perceived source of pertinent knowledge.

The results reveal that the firm Alpha benefitted in each of the phases from the customer contribution but in different ways. The results indicate that the knowledge content gradually shifts from expectations and demands to technical requirements, ideas for solutions, evaluation and validation of system feasibility, and optimization of the physical product. In addition, the findings reported in this paper indicate that the use of knowledge integration mechanisms is based on a complex interplay between various aspects of knowledge integration, related to the knowledge content, knowledge integration mechanisms, and the perceived source of pertinent knowledge. Throughout the product development process, based on emerging insights and changing perspectives, and in relation to the requirements in each of the phases, knowledge integration mechanisms, practices and activities are repeatedly revised and reestablished. Here, the analysis points out that the initial perceptions on "who knows" might be overturned throughout. Consequently, the perceived location of pertinent knowledge evolves over time, leading to the establishment of new ways to integrate knowledge.

The findings reported in this paper reveal that knowledge integration with customers 
can be viewed as a multi-level phenomenon, comprising many aspects that need to be considered. Thus, the knowledge content, knowledge integration mechanisms, and the perceived source of pertinent knowledge are useful aspects to analyze when aiming to elucidate different knowledge integration efforts. Considering these three aspects, Table 17 provides an overview of knowledge integration with the customer.

\subsubsection{My contribution to the paper}

I wrote Paper 2 in collaboration with Nicolette Lakemond and Stefano Brusoni. While I collected the data, Stefano Brusoni supported me in developing the data analysis with comments and feedback. In addition, Nicolette Lakemond's comments on the theoretical framework helped to formulate the findings and contributions. 


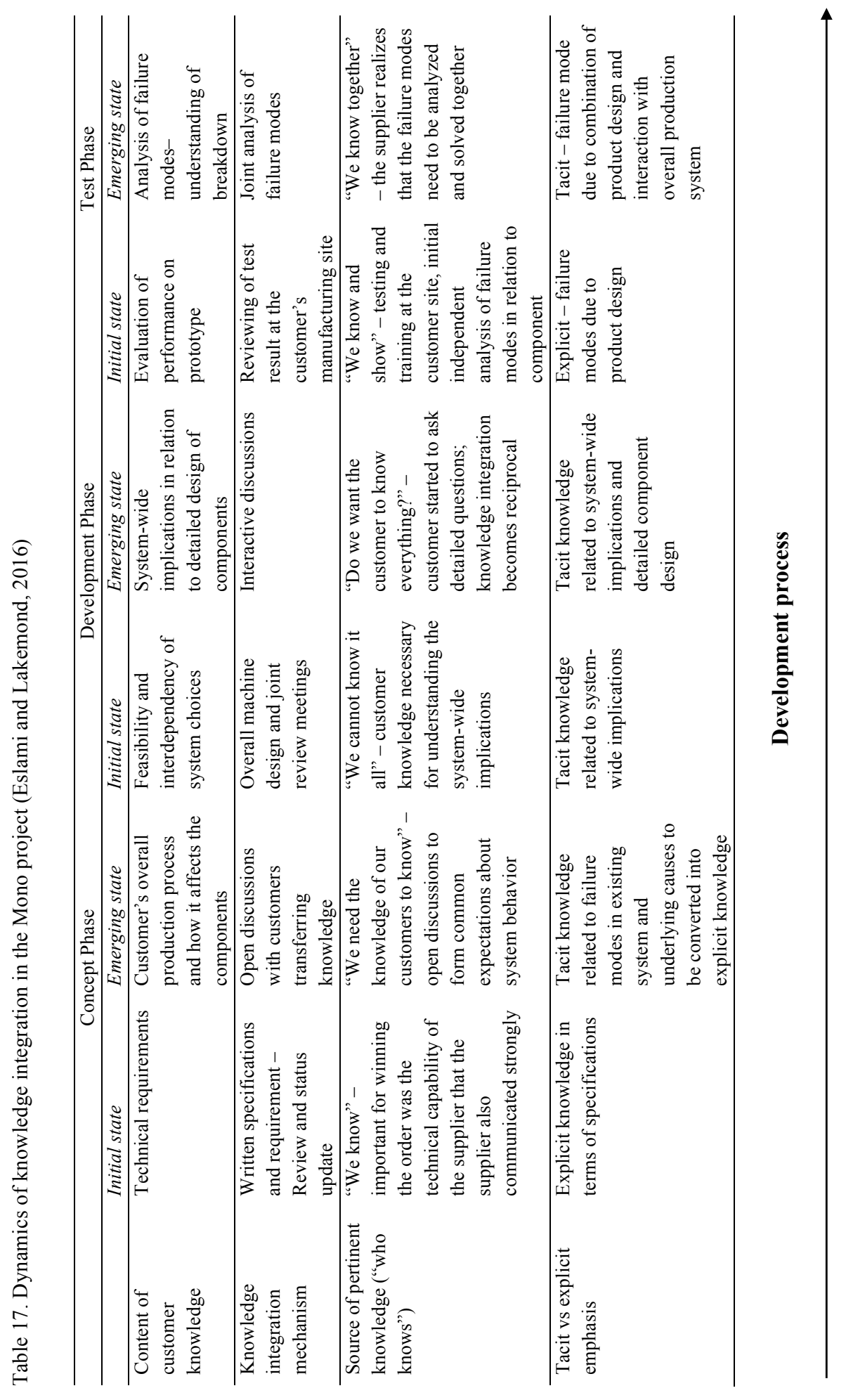




\subsection{Paper 3}

\section{Internal Integration in Complex Collaborative Product Development Projects}

\subsubsection{Summary}

Paper 3 focuses specifically on internal integration within firms. Many studies have emphasized the importance of internal integration for external collaboration in collaborative product development projects. In this context, cross-functional integration has been advocated as important. However, only a few studies deeply investigate different approaches for crossfunctional integration in relation to the conditions created in specific situations and when multiple external partners are involved.

Therefore, this paper investigates internal integration approaches in collaborative product development projects when collaborating with external partners, such as suppliers. For this purpose, the paper builds on an empirical study of a collaborative product development project (Muse) with four suppliers of different subsystems at Elekta company.

The results of the case study reveal three distinct approaches to internal integration as part of a collaborative product development project. As each of these approaches relates to the degree of task uncertainty, their adoption implies that different task characteristics in complex projects can drive the internal integration approaches. Based on the information processing theory, these approaches are distinguished based on three dimensions: lateral mechanisms, level of permanence, and information richness. Based on this classification and the empirical study, we identify three approaches: (1) multidirectional integration, (2) delimited problem solving, and (3) unidirectional integration.

The first approach (multidirectional integration) is driven by a high degree of supplier task uncertainty and, consequently, a high degree of internal integration. This approach offers the opportunity for rich communication exchange between customers and their suppliers (manufacturing firms) (cf. Daft and Lengel, 1986). The second approach (delimited problem solving) is needed in cases characterized by a moderate degree of uncertainty and continues as long as technical issues remain. The third approach is information oriented, and is employed when uncertainty associated with a supplier task is very low. This approach is characterized by periodic information exchange and involves a unidirectional integration.

The findings reported in Paper 3 support some results of previous studies in the field (Hillebrand and Biemans, 2004; Takeishi, 2001), highlighting the need to distinguish different types of internal integration that should be adopted in different conditions. Therefore, the case study reveals that uncertainty related to the supplier tasks determines the need, and the approach adopted, for internal integration. Such a differentiated approach might provide more effective ways to even integrate knowledge in customer-supplier relationships in product development projects. 


\subsubsection{My contribution to the paper}

I collected the data utilized in the analysis, reported in Paper 3, during my master thesis. Nicolette Lakemond supported me in developing the ideas underpinning the paper at the beginning of my $\mathrm{PhD}$ study. I re-analyzed the data, framed the literature review, and wrote the first draft of the paper. Nicolette Lakemond then supported me with comments during the development of the paper.

\subsection{Paper 4 \\ Knowledge integration with customers in innovation: Empirical evidence from Swedish manufacturing firms}

\subsubsection{Summary}

Previous research has delineated the many benefits of using knowledge in firm's innovation processes (e.g., Callahan and Lasry, 2004; Fang et al., 2008; Enkel et al., 2005; Lau, 2011). Authors of previous studies posit that engaging customers in product development can allow firms to obtain new insights and improve product designs, as well as utilize their internal resources better (Greer and Lei, 2012). Despite these and other benefits of customer knowledge contribution in innovation, some existing studies have demonstrated that customer collaboration does not guarantee success. Several authors are of view that more extensive collaboration with customers is not always beneficial, as it may increase the costs associated with monitoring, as well as introduce communication problems (Emden et al., 2006; Lui et al., 2006; Brockhoff, 2003). These studies point to the complex relationship between customer collaboration and product development performance. Their findings thus indicate that firms should carefully consider the mechanisms and practices pertaining to customer knowledge contribution. However, only a few studies have examined how and in what situations firms can benefit from collaborative product development with customers in relation to knowledge integration.

In order to increase the understanding of how and when firms can benefit from collaborative product development with customers, the present study explores these phenomena from the knowledge-based view of the firm. The aim is to investigate the role of knowledge integration with customers and its associated effects on two performance variables, innovation efficiency and innovation novelty. In addition, the goal is to establish whether the effect of this endeavor depends on the phases of product development and degree of product uncertainty. This has resulted in the following hypotheses that were tested in the study:

H1: Knowledge integration with customers has a positive effect on innovation novelty.

$\mathrm{H} 2$ : Knowledge integration with customers has a negative effect on innovation efficiency.

H3: Knowledge integration has a positive effect on innovation novelty in each of the phases of the product development process. 
H4: Knowledge integration has a negative effect on innovation efficiency in the early phases and a positive effect on innovation efficiency in the later phases of the product development process.

H5: The positive effects of knowledge integration with customers on innovation novelty are strengthened when product uncertainty increases in each of the phases of the product development process.

H6: The negative effects of knowledge integration with customers on innovation efficiency are strengthened when product uncertainty increases in each of the phases of the product development process.

Based on a cross-sectional survey of 216 Swedish manufacturing firms, the paper provides strong evidence in support of the positive effect of knowledge integration on innovation efficiency (Hypothesis 1). Contrary to the initial expectations (Hypothesis 2), knowledge integration does not support a negative effect of knowledge integration with customers on innovation efficiency. In addition, an analysis of the role of knowledge integration in relation to the degree of customer collaboration in each of the phases of the product development process reveals that integrating knowledge with customers has a positive effect on innovation efficiency. However, this effect is exerted mainly in the later phases of the product development processes, as its influence in the initial phases is not significant (Hypothesis 4). In contrast, knowledge integration with customers has a positive effect on innovation novelty in all of the product development phases (Hypothesis 3). Finally, in line with the initial expectations, the results show that product uncertainty moderates the relationship between knowledge integration and innovation novelty (Hypothesis 5), but not innovation efficiency in different phases of the development project (Hypothesis 6).

\subsubsection{My contribution to the paper}

The idea of this paper was developed in collaboration with Nicolette Lakemond. I was responsible for conducting the survey of Swedish manufacturing firms. Together with Nicolette Lakemond, we analyzed the data based on jointly formulated research questions. Thereafter, I formulated the theoretical framework and hypotheses, supported by Nicolette Lakemond. We also jointly formulated the discussion and contributions. 


\subsection{Paper 5}

The role of technical capabilities and locus of initiative for knowledge integration with customers in collaborative product development: Evidence from a survey-based study

\subsubsection{Summary}

The main objective of the fifth paper is to understand the effect of situational factors on knowledge integration with customers in product development. The initial idea was based on the results from the case studies reported in Papers 1 and 2. A complementary literature review conducted as a part of this investigation revealed surprisingly few studies providing the theoretical foundation for investigating the effects that different factors have on knowledge integration with customers. In addition, although previous research has started to adopt the procedures used for the integration of external knowledge (i.e., in relation to the governance mechanisms used to integrate external knowledge), few studies have investigated the factors that influence knowledge integration with customers.

In an effort to extend previous insights into knowledge integration with customers in product development, we formulated four hypotheses to investigate how specifically a firm's technical capability and the locus of initiative affect knowledge integration. In the paper, we formulate the following hypotheses:

H1: A firm's internal technical capability has a positive effect on knowledge integration with customers in collaborative product development.

H2: A customer's technical capability has a positive effect on knowledge integration with customers in collaborative product development.

H3: A congruence of technical capabilities in terms of simultaneously high degrees of firminternal and customer-technical capabilities is associated with higher levels of knowledge integration activities than when one or both have a low degree of technical capability.

H4: The locus of initiative residing with customers has a positive effect on knowledge integration with customers in collaborative product development.

We conducted a survey among the representatives of 216 Swedish manufacturing firms to elucidate the manner in which the two specific factors - technical capability and locus of initiative - influence knowledge integration with customers. The empirical results offered support for all the suggested hypotheses and revealed that the firm's and customer's technical capabilities and the locus of initiative of the supplier and customer have a positive effect on knowledge integration with customers.

\subsubsection{My contribution to the paper}

I framed the research question of the paper and conducted the survey, while Nicolette Lakemond supported me in the data analysis. Further, I wrote the whole paper, and Nicolette Lakemond commented on it. 


\section{Discussion}

This chapter discusses the contributions of the research presented in the five appended papers in relation to the research questions. Based on the results of the papers and the literature, each of the research questions guiding the overall study is discussed.

\subsection{Research question 1 \\ How do firms integrate customer knowledge in a collaborative product development processes?}

The first research question concerns how firms integrate customer knowledge in collaborative product development processes. This question is mainly answered in the conclusions sections of Papers 1 and 2. The work presented in Paper 1 aimed to elucidate the type of knowledge customers contribute in product development and the timing of their input. In addition, Paper 2 focuses specifically on how knowledge integration with customers in product development dynamically changes over the different phases of the development process.

Developing a product development project typically requires the firm and the customer to perform different tasks and collaborate in a way that benefits each of the phases of this process (Engwall and Westling, 2004). In fact, the contributions and activities can vary quite a lot over the development process. As a result, the customer knowledge contributions and mechanisms must be aligned with the firm's needs in order to benefit fully from this collaboration. Scholars have argued that more research is necessary to understand how firms can organize their collaboration with customers in product development (Hauser et al., 2006). In relation to the above, this would imply that this research needs to take into account the relationship between the focus of the specific phases of the development process, the customer contribution, and the mechanisms for knowledge integration with customers. Consequently, knowledge integration needs to be addressed as being dynamic in character. This means that the knowledge integration mechanisms and practices must be capable of responding not only to the changing customer contributions but also to unexpected problems that can occur in product development and need to be solved quickly.

We have investigated the dynamics of the knowledge integration with customers investigated, by examining the content of knowledge that customers contribute during the product development process and how this contribution can change and evolve. Based on this, we have explored how customers' knowledge is integrated in the product development process.

\subsubsection{Content of the customer's knowledge contribution}

Customer knowledge is the input by the customer, which is necessary to overcome technical challenges that might arise during the product development process (Peled and Devir, 2012). In accordance to our expectations, in Paper 1, we showed that the contributions and responsibilities of both firms and customers were related to the phases of the product 
development process. In this paper, following the idea of the stage-gate system (Cooper and Edgett, 2012), we consider three phases in which knowledge is gathered and integrated: concept, development, and testing.

Considering the timing of customer contribution, authors of previous studies have identified different roles that customers can adopt in product development (e.g., Nambisan, 2002; Blazevic and Lievens, 2008; Fang et al., 2008; Helm and Salminen, 2010; Aarikka-Stenroos and Jaakkola, 2012). Guided by this view, the results reported in Paper I provide additional insights into how customer knowledge contribution aligns with these recognized customer roles, as well as how it varies across the product development phases.

The findings of Papers 1 and 2 show that, during the concept phase, knowledge integration focuses on clarifying customer expectations in terms of the technical requirements of the new product. This is consistent with the view promoted by Fang (2008), who noted that customers can act as information providers regarding market needs, which is important for new product success. Therefore, customers can provide more insights into the challenges that they experience with existing solutions, potentially leading to more effective new solutions. By integrating the knowledge of customers, firms can become aware of existing problems and use their customers' knowledge to prevent these from becoming embedded in the new product. In this situation, firms rely on the knowledge of their customers to create an understanding of the product, potential problems, and demands related to the use of the product by the customers.

During the development phase, the content of knowledge integration with customers shifts from expectations related to product specifications and potential challenges to more detailed input related to system interdependencies and functionality. The system or component provided by the manufacturing firm needs to fit the customer's product; therefore, knowledge relating to system-wide implications and functionalities is required (cf. Takeishi, 2001). In our empirical study on the Mono project, for example, initial knowledge integration between the firm and the customer during the development phase focused on interface specifications and design requirements. The interdependency, in this specific case, was based on a set of codified rules that stipulate how the subsystems may affect other systems comprising the customer's product. However, while the firm provided components and subsystem modules that are assembled in the customer's overall product, knowledge integration extended beyond the integration of knowledge these parties possess. This is also in line with what other researchers have proposed (e.g., Zirpoli and Camuffo, 2009). This situation may take place when some emergent behaviors arise from the incorporation of a firm's system into other systems of the customer's product. The customer's role in this situation is in line with the idea of a customer acting as co-designer (Nambisan, 2002). Hence, the customer's knowledge of system feasibility and design issues needs to be integrated, as it will assist the firm in solving any unforeseen problems.

In addition, during the test phase, as the results in Papers 1 and 2 reveal, the knowledge content that the firm needs to integrate with the customer changes from defining physical interdependencies to evaluating the physical product. For instance, during the testing phase in the Solar project, both the firm and the customer determined how the system functioned in 
conjunction with adjacent systems in the customer's product in order to identify opportunities to improve the overall system performance. This is in line with the customer's acting as a user (Blazevic and Livens, 2008), whereby the customer shares feedback and suggestions with the firm on failure modes and system optimization possibilities.

\subsubsection{Knowledge integration mechanisms with customers}

Although authors of existing studies have proposed mechanisms for accomplishing knowledge integration (e.g., Grant, 1996), it is presently unclear how these mechanisms are relevant to customer collaboration in product development and how the utilization of these mechanisms evolves through the product development phases. This study aimed to address this gap in the current knowledge by identifying the process drivers and mechanisms that are used to integrate the customer's knowledge contribution. From the results presented in Paper 2, we identified three patterns of knowledge integration mechanisms: conventional product management, joint problem framing, and joint problem-solving mechanisms. These three mechanisms are repeatedly revised and re-established by the firms and their customers in order to facilitate knowledge integration by promoting and restraining diversity in relation to the specific requirements of each project phase.

Conventional product management mechanisms are a way of managing the planned knowledge integration activities and is consistent with the sequencing mechanism discussed by Grant (1996). This type of mechanism is utilized to facilitate the traditional product management activities, such as status updates, reviewing requirements, specifications, designs, and test documents. The results of the second paper show that these activities aim to integrate knowledge between firms and customers that is pertinent to the development task, which proceeds as planned and usually continues throughout all phases of the development project. The goal is to reduce interpersonal communication and promote an even stronger time focus. This is in line with the findings reported in previous studies that focused on efficiency of integration (Grant, 1996; Grant and Baden-Fuller, 2004; Schmickl and Kieser, 2008). In such conditions, less communication is needed.

When firms and customers experience challenges and have to address some unforeseen issues that cannot be resolved and overcome by conventional knowledge integration mechanisms, joint problem-framing and joint problem-solving mechanisms are needed. These mechanisms can be adopted in conjunction with group problem-solving strategies (Grant, 1996). Empirical evidence indicates that this approach is particularly valuable when firms and customers encounter several difficulties when using conventional mechanisms. The results of our study indicate that group problem-solving strategies can be focused on problem-framing as well as problem-solving activities. Problem framing is necessary not only in the early phases of product development but also when firms and their customers experience severe difficulties and problems in the product development process that they jointly need to understand. In this situation, representatives from firms and customers focus on using their knowledge in order to identify the problem's different dimensions and causes, which requires a greater understanding of the problem as a whole. For example, during the test phase, the firm and the customer can 
work collaboratively, by conducting joint analyses, to identify the cause of breakdowns. If the problem happens rather unexpectedly, it needs to be approached from various perspectives as this expedites the problem-solving process.

In addition to joint problem framing, firms and customers also seem to use joint problem solving to apply different forms of knowledge to generate and evaluate potential solutions and jointly identify the most optimal one. For instance, during the development phase in the Mono project, firms had to engage in interactive discussions with the customer in order to resolve disagreements regarding the interfaces. This involved adjustments and recalculations of the design, which were dependent upon the customer's knowledge.

This study found that open discussions, interactive communication, joint analyses, and other such activities are useful for joint problem framing and problem solving. These activities enable knowledge integration and faster progression through the development process. They promote and restrain diversity in relation to the solutions required in the actual situations encountered in each of the project phases. Table 18 shows the knowledge integration mechanisms and content of customer knowledge for each of the project development phases.

Table 18. Content and mechanisms of knowledge integration

\begin{tabular}{|c|c|c|}
\hline Phases & Content of knowledge integration & $\begin{array}{l}\text { Mechanism of knowledge } \\
\text { integration }\end{array}$ \\
\hline \multirow[t]{2}{*}{ Concept phase } & $\begin{array}{ll}\text { - } & \text { Customer expectations } \\
\text { - } & \text { Technical requirements and specifications }\end{array}$ & $\begin{array}{l}\text { Written specification } \\
\text { and requirement }\end{array}$ \\
\hline & - Conceptual challenges and problems & - Open discussion \\
\hline \multirow[t]{2}{*}{$\begin{array}{l}\text { Development } \\
\text { phase }\end{array}$} & $\begin{array}{ll}\text { - } & \text { Functionality and system interdependency } \\
\text { - } & \text { System feasibility }\end{array}$ & - Joint review meetings \\
\hline & $\begin{array}{l}\text { - System wide implications in relation to } \\
\circ \quad \text { Detailed design of components / } \\
\circ \quad \text { Design challenges and } \\
\text { disagreements }\end{array}$ & $\begin{array}{l}\text { - Interactive round } \\
\text { discussion }\end{array}$ \\
\hline \multirow[t]{2}{*}{ Test phase } & $\begin{array}{l}\text { - Evaluation of optimization and performance } \\
\text { of physical product }\end{array}$ & $\begin{array}{l}\text { - Test evaluation } \\
\text { review }\end{array}$ \\
\hline & $\begin{array}{l}\text { - Failure modes and understanding of break- } \\
\text { down }\end{array}$ & $\begin{array}{l}\text { - Joint analysis } \\
\text { meeting }\end{array}$ \\
\hline
\end{tabular}




\subsection{Research question 2 \\ What situational factors affect customer knowledge integration in collaborative product development?}

The results of this study indicate that firms need to not only consider how they integrate knowledge with customers but also recognize the factors that can affect integration outcomes. The present study revealed three factors (internal integration capability, technical capability, and locus of initiative) that can be particularly important for firms to understand. The relevance of these factors is situation dependent and may require selecting different approaches for integrating knowledge with customers. How the three factors affect knowledge integration with customers is explained below.

\subsubsection{Internal integration capability}

Authors of previous studies are of view that, when the firm's internal communication is inadequate, it is difficult to realize a technology's potential and effectively integrate complementary knowledge inter-organizationally (e.g., Hillebrand and Biemans, 2004; Mishra and Shah, 2009). Conversely, an appropriate level of collaboration among the internal functions of firms would facilitate external knowledge integration. In line with these assertions, the results discussed in Paper 3 show that firms lacking internal integration approaches would be fragmented and disconnected. Under such circumstances, firms are not able to plan their activities or solve the problems with their external partners in collaborative product development projects. Therefore, it seems that effective internal integration is a necessary precondition for external knowledge integration during product development (cf. Koufteros et al., 2005).

In previous studies, researchers have also highlighted the importance of cross-functional integration among internal functions and its positive effect on external integration (Song et al., 1997; Wheelwright and Clark, 1992). However, it also seems that increasing the degree of internal integration does not always guarantee better product performance (Felin and Zenger, 2014). In existing studies, internal integration approaches in collaborative product development projects have not been explored in detail. Given the limitation that more integration does not necessarily always lead to better results, firms must utilize approaches to internal integration that are aligned with the specific needs of the product development process and its contextual conditions (c.f. Hillebrand and Biemans, 2004; Droge et al., 2004). In Paper 3, we investigated a collaborative product development project including different systems that the customer developed, which involved different internal functions and several suppliers.

The study results include the formulation of differentiated approaches to internal integration that are dependent on the degree of system or product task uncertainty. The empirical study yielded three integration patterns: multidirectional, delimited problem-solving, and unidirectional approaches. The first approach is driven by high task uncertainty and, consequently, needs intense communication among internal functions (Daft and Lengel, 1986). This approach offers the opportunity for frequent face-to-face communication among 
representatives of various internal functions to discuss technical issues and contribute more valuable insights during the product development processes. The second approach, delimited problem solving, is adopted with a moderate degree of task uncertainty in which integration exists as long as technical issues remain. The third approach is associated with a low level of task uncertainty and takes place intermittently, in order to obtain status updates and exchange information (Wheelwright and Clark, 1992).

\subsubsection{Technical capability}

A firm's capability of integrating knowledge with customers could be a reflection of the technical capability of both the firm and its customers (Rundquist and Halila, 2010). In order to manage knowledge integration with customers more effectively, firms need to be proficient in the latest technology and strive to incorporate external technology where applicable. Based on the findings of the case studies discussed in Paper 1, which were confirmed in the survey study reported in Paper 4, we posit that technical capability is an important factor embodied in employees' knowledge, which helps firms to share their knowledge and discuss new solutions and technologies with customers. In this way, firms can offer a high degree of engineering support to their customers and respond quickly to technological changes (cf. LaBahn and Krapfel, 2000).

However, possessing technical capability is insufficient to facilitate knowledge integration between firms and customers. In Papers 1 and 5, we demonstrated that customers also need to have a sufficient technical capability in order to be able to help in new product design and production processes. In the Mono project, for example, considerable technical knowledge that allowed the customer to provide insights relevant to different phases of the development process was an important requirement for extensive knowledge contribution by the customer. This finding is in line with the results of some of the previous that identified new approaches to customer contribution to the firm's activities (Athaide and Klink, 2009). For instance, Athaide and Klink (2009) pointed out that collaboration with customers with a high technical capability helps to alleviate environmental uncertainty and increase adaptation. This assertion suggests that collaboration with technically capable customers increases the likelihood of creating joint value.

\subsubsection{Locus of initiative}

The results of the present study highlight the importance of firms' and their customers' internal and technical capability. However, these capabilities are difficult to assess before considering the level of commitment. Previous research points to the fact that collaborating intensively with customers with the purpose of increasing innovation requires willingness from both parties to achieve the required knowledge and capabilities (e.g., Krause et al., 2007). Mutual commitment in the relationship between a firm and its customer can help them to focus on their tasks without worrying about each other's intentions, resulting in a greater likelihood of a successful exchange of resources (Ritter and Walter, 2003). From the customer collaboration study, in 
which 216 manufacturing firms were surveyed, we found that the intention exhibited by both customers and firms served as a driver of knowledge integration. This commitment results in reliable and successful collaboration, which helps identify the type of knowledge that needs to be exchanged (Fang et al., 2008).

Exploring, in Paper 1, how commitment can affect customer knowledge contribution, we found the relevance of the initiative behind knowledge integration with customers. In the case studies discussed in this paper, commitment emerged from the locus of initiative. In fact, if customers take the initiative, they have an active role and are willing to contribute their knowledge in a product development project. A similar finding was reported by Brockhoff (2003), who observed that, if the customer takes the initiative, firms can expect to receive complaints and suggestions on pertinent product characteristics. In this situation, the aim of knowledge integration with customers included obtaining expectations and technical requirements with respect to product feasibility, along with the evaluation of the physical product optimization. In contrast, based on the case studies discussed in Paper 1, if the project was initiated by the firms, they would be unable to motivate the customer to provide feedback. In this situation, firms need to put considerable effort into convincing the customer that the product has value for them. Therefore, in this situation, knowledge contribution could be more limited.

\subsubsection{Relationship between technical capability and locus of initiative}

Paper 1, while considering the locus of initiative and technical capability, identified three situations regarding the timing of knowledge integration with customers.

In the first situation, customer knowledge contribution takes place through the concept, development, and testing phases. One of the important requirements for intense contribution from customers is considerable technical knowledge that can be drawn on during all the project development phases. In the Mono project, the intense contribution from the customer was reinforced by the fact that the customer had taken the initiative for the development. The role of the customer in this situation is in line with the idea of the customer as co-creator, who engages in every aspect of development process (Nambisan, 2002; Fang, 2008).

In the second situation, knowledge integration with customers is not as far-reaching. Consequently, the customer contributes knowledge in the ideation and testing phases of the project development. These contributions during the early and late phases are characteristic of a facilitative firm-customer relationship, in which both parties are willing to contribute to pertinent activities (Lagrosen, 2005). Two scenarios could account for this situation. The first scenario could happen when the technical capability of the firm is high and the firm takes the initiative for the project. This was shown in the Solar project, where the customer had a technical understanding of the project but did not seem inclined to contribute during the development phase before verifying the solution's effectiveness. Alternatively, the second scenario appears when a customer with low technical capability takes the initiative for the project. Here, customers might intend to contribute intensely, but their lack of technical knowledge limits their contribution in the development phase. 
In the third situation, customer knowledge contribution is limited to the concept phase. This was evident in the Fra project, in which the firms rarely interacted with the customer. The main reason was the customer's lack of technical capability, making further contribution in developing the material superfluous. In this situation, the customer takes the role of a resource (cf. Coviello and Joseph, 2012) and the timing of knowledge integration is usually confined to the concept phase of the project. Limited knowledge integration with the customer is also driven by the locus of initiative, which resides with the firm. Table 19 shows an overview of the three situations that affect the timing of knowledge integration with customers in a product development project. 
Table 19. Different timings of knowledge integration with customers

\begin{tabular}{l|l|l|l|l}
\hline & Situation 1 & \multicolumn{2}{|l|}{ Situation 2 } & Situation 3 \\
\hline $\begin{array}{l}\text { Timing of customer } \\
\text { collaboration }\end{array}$ & $\begin{array}{l}\text { Ideation, development, } \\
\text { and testing phase }\end{array}$ & \multicolumn{2}{|l}{ Ideation and testing phase } & Ideation phase \\
\hline Locus of initiative & Customer & Customer & Supplier & Supplier \\
\hline $\begin{array}{l}\text { Customer's } \\
\text { technical capability }\end{array}$ & High & Low & High & Low \\
\hline Customer roles & Co-creator & User & & Resource \\
\hline
\end{tabular}

\subsection{Research question 3}

\section{How does knowledge integration with customers during product development affect innovation performance?}

In most studies in the field of customer collaboration, researchers attempted to evaluate the impact of customer contribution on product performance. In many such cases, customer collaboration was found to positively influence the firm's innovativeness (e.g., Lin et al., 2010; Lau, 2011; Lin and Huang, 2013). However, in these works, the effect of knowledge integration with customers (characterized as a process) on innovation performance (novelty and efficiency) was insufficiently explored, and the reported findings were inconsistent.

In order to address this shortcoming, Paper 4 aimed to investigate the aforementioned relationship by conducting a survey of 216 manufacturing firms. The subsequent analysis of the survey responses revealed that knowledge integration with customers in collaborative product development has a positive effect on both innovation novelty and efficiency. This finding allowed categorizing the degree of product uncertainty and timing of customer collaboration for the purpose of establishing if these varying conditions would have different effects on innovation performance. The findings are discussed below.

First, based on the results obtained in existing research, it was hypothesized that the relationship between knowledge integration and innovation novelty would be stronger when the perceived uncertainty is high (e.g., Song and Montoya-Weiss, 2001). The study findings pertaining to this relationship indicated that knowledge integration allows firms to combine and synthesize their complementary knowledge bases as a means of reducing ambiguity and uncertainty. However, in relation to efficiency, the analyses revealed that the relationship between knowledge integration and innovation efficiency is weaker when product uncertainty is high. In such situations, a high degree of communication is recommended, as application of different types of knowledge is necessary to fill the gap between what is known and the knowledge required. This form of collaboration can be costly, as it requires formation of multidisciplinary teams, whose members must work together for integrating knowledge.

Second, considering the timing of customer collaboration, an analysis of knowledge integration with customers was performed on each of the development process phases. Findings related to the role of the knowledge integration phase reveal that knowledge integration has a positive 
effect on innovation novelty in all phases of the product development process. This result is in line with that reported in Paper 1 and is consistent with some previous studies, which suggest that customer collaboration is not limited to the early stages, but is rather highly important during later stages. Indeed, empirical evidence shows that customers can assist with the validation of the product's architectural choices, the specification of product interface requirements, and the establishment of development process priorities (Nambisan, 2002; Eslami and Lakemond 2016). In contrast, in relation to innovation efficiency, during the early stages of product development, knowledge integration has no effect on innovation efficiency, which becomes positive in the later stages. These contrasting findings may imply that such interaction is less efficient in the early stages because it may be difficult to capture the latent preferences of the customer through knowledge integration without being able to provide the customer with an experience of the new product (Greer and Lei, 2012). However, more extensive problems tend to emerge during the later phases because firms use prototypes and product testing to achieve meaningful knowledge integration with customers. Therefore, knowledge integration with customers may be important in this phase, as it allows firms to overcome these problems quickly.

Although studies discussed in Papers 1, 2, and 3 were not designed to directly investigate the effect of knowledge integration on innovation performance, they provided initial though important results, suggesting the presence of other indicators of organizational performance. For instance, one of the assumptions underpinning these studies was that a collaborative product development project could be successfully accomplished by adopting appropriate knowledge integration mechanisms and possessing the requisite capabilities. The findings of these studies are important in terms of a firm's performance, as they support the idea that knowledge integration mechanisms, technical and internal capability, and commitment can positively influence the outcome of knowledge integration between the firm and the customer, which may in turn influence performance. Therefore, the overall findings indicate that these mechanisms and factors are important for knowledge integration during product development, potentially resulting in enhanced innovation capacity of the firm. 


\section{Conclusion}

This chapter discusses the theoretical and practical contributions of the study on knowledge integration with customers in product development. Section 6.1 describes some main theoretical contributions. Section 6.2 outlines the practical contribution and provides some recommendations for firms that collaborate with their customers in product development. Finally, the limitations of the study are presented, and suggestions for future research in the field of customer collaboration in product development are discussed.

\subsection{Theoretical contribution}

Guided by the purpose of the investigation, this study set out to provide an increased understanding of customer collaboration in product development, especially in regard to how firms can integrate their customers' knowledge. Thus, the study was not motivated by the lack of studies in the field of customer collaboration, but rather by an identified gap in the understanding of customer collaboration from a knowledge-based view of the firm, which signals that knowledge integration is the key. This view of the firm as a knowledge-bearing entity is supported by several studies (cf. Foss, 1996). While using the knowledge-based view as the dominant theoretical perspective, the study's theoretical contribution must be mainly seen in relation to the literature on customer collaboration in product development. This literature has emphasized the increasing importance of customers when developing new products, but has not yet been able to provide conclusive results on how firms can benefit from customer collaboration in product development. By investigating customer collaboration based on and in relation to the implications of the knowledge-based view of the firm, at the outset of the study, it was expected that additional insights into customer collaboration could be determined. Using the knowledge-based view of the firm, the study focused on several important aspects. With this theoretical lens, it becomes clear that both firms and their customers are knowledge-bearing entities. It thus emphasizes that customers' knowledge is central to the act of customer collaboration. This implies that the customers' contributions can be considered in the light of the characteristics of knowledge. The use of the knowledge-based view stresses that knowledge integration is crucial and that further understanding of knowledge integration and its dynamics is important. This resulted in a focus on knowledge integration mechanisms and practices in relation to the different phases of product development.

The study addresses the call for further research in the area of customer collaboration, especially in regard to how firms can organize their collaboration with customers in product development (Hauser et al., 2006). Integrating the customer's knowledge as part of the product development process enables firms to react to market changes expediently, while knowledge integration with customers also facilitates the development of new products and solutions for products. In line with previous results, in the field of customer collaboration, this study emphasizes customer collaboration throughout the product development processes. While previous research has 
mainly focused on initial phases, or has not made a distinction between different phases of the product development process (e.g., von Hippel, 1976; Griffin and Hauser, 1993; Billington, 1998; Thomke and Fujimoto, 2000; Paustian, 2001; Dahan and Hauser, 2002), this study particularly addresses knowledge integration with customers in relation to phases of the development process (e.g., idea generation, concept development, engineering, and test). Therefore, this study shows that firms collaborate with customers to not only identify needs and problems but also assess architectural aspects, jointly develop solutions, and address development challenges that emerge over time. With this focus, this study aimed to provide indepth insights into customer collaboration while addressing the customer's knowledge contribution, knowledge integration mechanisms and practices, and the prerequisites of product development in relation to the different phases in an integrated way. The absence of such a focus in previous research, in combination with the increasing importance of customer collaboration, was the main motivation for the present study.

Previous studies on the relationship between the customer's knowledge contribution and specific phases of the product development process have emphasized that customers can have different roles in product development (Lilien et al., 2002; Nambisan, 2002; Blazevic and Lievens, 2008; Fang et al., 2008; Coviello and Joseph, 2012; Huang and Chu, 2010). The present study contributes to this body of the literature by extending these roles and expressing them in terms of, and relation to, customers' knowledge contribution and the timing of knowledge integration. The results of the present study partly complement some of the previous studies (Kaulio, 1998; Lagrosen, 2005) and reveal that customers can contribute not only in the early phases of the product development process but in other phases as well. In this respect, knowledge integration with customers may allow the firm to identify and address issues related to technical and specification requirements and product feasibility. Doing so in the early phases of the product development process mitigates development challenges. In addition, customer input is beneficial in product design optimization, as well as joint analyses of the test results that are utilized in the subsequent phases of the development process. Knowledge integration may be particularly important in addressing the architectural aspects, system-wide implications, component solutions, and operational prerequisites of complex product development systems being designed. Some of these seem to be tacitly embedded in the firms and their customers' accumulated experiences, and some of these are more easily addressed explicitly. Collaborative product development with customers thus entails what Kogut and Zander (1992, p. 384) have described as "social communities in which individual and social expertise is transformed into economically useful products and services by the application of a set of higher-order organizing principles." These principles represent, for example, knowledge integration mechanisms, such as those proposed by Grant (1996), that effectively and efficiently help to connect different knowledge bases. Consequently, this study of knowledge integration with customers in collaborative product development acknowledges that customers may play an important role in shaping the knowledge-based competitive advantage of firms. The results of the survey study that are reported in Papers 4 and 5 appended to this extended summary confirm this by demonstrating the importance of knowledge integration with customers for innovation performance, both in terms of novelty and efficiency. Knowledge integration is thus applied as a "higher-order organizing principle," in inter-firm settings. 
With respect to the knowledge integration mechanisms, existing research (e.g., Okhuysen and Becky, 2009; Tell, 2011) indicates that knowledge integration, and thus the use of knowledge integration mechanisms, is dynamic in character. Recognizing this fact, the present study elucidates the dynamic character of customer's knowledge contributions, while also delineating the processes underlying knowledge integration. This was achieved by investigating how the underlying mechanisms and activities evolve during the product development process. According to Okhuysen and Bechky's terminology, knowledge integration process can be influenced by everyday dynamics and can be repeatedly interrupted by different problems. Failure to address these issues can risk the success of the knowledge integration effort, especially if a firm is not capable of adjusting its knowledge integration mechanisms. As was shown by the present study, utilizing different knowledge integration mechanisms, such as conventional project management, joint problem framing, and joint problem solving, might be necessary during each project. One of the main contributions of the current research stems from elucidating the benefits and drawbacks associated with the use of the aforementioned knowledge integration mechanisms, rather than identifying or conceptualizing new types of mechanisms. In fact, the use of knowledge integration mechanisms and their adjustment to the specific needs of each of the product development phases was found to be closely linked to the manufacturing firm's perceptions of the knowledge and expertise levels of customers and, hence, their ability to contribute to the product development effort. The results of this particular part of the study indicate that knowledge integration mechanisms are repeatedly revised according to an emerging perception of the knowledge contribution needed by the customer. This view was triggered by different events which revealed that the existing perception on who knows was either wrong or had become outdated as a result of the progress made in the product development phases. Consequently, the results of the present study point to not only the role of knowledge and knowledge integration in collaborative product development with customers but also its complex and dynamic character.

The present study also provides indications for a situational approach towards knowledge integration with customers in collaborative product development. Authors of previous works have examined the role of internal technical capability (LaBahn and Krapfel, 2000), in line with arguments that firms utilize prior knowledge when assessing the value and practical utility of new information, before deciding whether to assimilate it and apply it to commercial ends (cf. Cohen and Levinthal, 1990). Firms' internal integration and technical capability are also relevant, based on the knowledge-based view of the firm, which stipulates that knowledge is accumulated through experience (e.g., Kogut and Zander, 1992). In collaborative product development with customers, the customer's technical capability represents an important part of the knowledge stock of the customer that needs to be integrated with the firm's knowledge. This assertion is in line with the findings reported by other authors, who view the customer's technical capability as an important situational factor (e.g. Athaide and Klink, 2009). They are also supported by prior studies indicating that important complementary knowledge may reside with an external actor (e.g., Grant and Baden-Fuller, 2004). According to the findings of the present study, these capabilities are difficult to assess before considering the customer's level of commitment and willingness to attain the required knowledge and capabilities (Gadde and 
Snehota, 2000). In particular, the results of our study point to the fact that active customers who take the initiative in collaboration have a positive effect on knowledge integration. Consequently, requisite technical capabilities and locus of initiative seem to be important situational factors that can determine the outcome of knowledge integration with customers.

Knowledge integration with customers is highly dependent on the motivation of both parties. Kogut and Zander (1992) argue that a social community performs actions voluntarily. In the context of this present study, this assertion implies that technical capability and the locus of initiative for collaborative product development would determine the outcome of these actions. For example, when customers are willing to collaborate and possess the requisite technical capability, knowledge can be integrated through different phases by employing the problemsolving and problem-framing mechanisms. In addition, both the firm and the customer must be committed to extensive communication and take part in ongoing dialogue. However, such timeconsuming integration is not always desirable, especially if the customer lacks technical capabilities, or cannot devote the required time to knowledge integration. In this situation, firms should focus on employing appropriate mechanisms that can ensure optimal integration and combination of knowledge bases in relation to the specific needs. In such cases, the goal is usually to increase efficiency by minimizing communication between customers and firms.

\subsection{Practical implications}

It has been argued that collaborating with customers during the product development process helps firms to quickly react to market changes and identify beneficial opportunities for moreextensive product development. However, not all firms recognize these opportunities due to the lack of management skills and capabilities. Therefore, many possibilities for improvements in collaborative product development projects still exist, some of which have important managerial implications.

First, the finding highlights the need for firms to adopt dynamic knowledge integration processes with the customer that would permit changes in the development process. The adoption of this process transforms knowledge integration activities and practices into ongoing accomplishments (Okhuysen and Bechky, 2009), which cannot be achieved through the traditional product development activities. It is therefore necessary for firms to remove the boundaries between consecutive product development phases by implementing a rich portfolio of activities and practices for integrating different types of knowledge. For example, firms facing challenges and disagreements with customers during the development phase can use problem-framing mechanisms to understand and identify the dimensions of the problem. This would enable them to revise some of the ideas that were developed in concept phase and use appropriate problem-solving mechanism to recalculate pertinent performance measurements to resolve the issues. Consequently, the dynamic practices and activities of knowledge integration would expectedly be beneficial for managers, who are required to demonstrate and facilitate sustained efforts for collaboration with customers yielding measurable outcomes. Similarly, practitioners may find some of the discussed activities and practices useful to consider when 
conducting self-assessment of their practices. Those who have not yet implemented the dynamic process should first identify the situational factors that are most relevant in their specific case and utilize these findings when developing the dynamic process. In fact, the findings of the present study indicate that the contingency perspective not only represents a theoretical concept but has important implications for practitioners.

Second, as firms are meeting the increasing demand for product development, they should recognize the value of customer contribution throughout the development process. In fact, this study suggests some factors that can help firms maximize the benefits gained from collaborative product development with customers. The empirical result shows that, when firms take the initiative in the project, customers are usually not motivated to participate in its development. The firms' influence on the customers could be limited in this situation, which therefore requires more attention from managers. Assessment of customer's technical capability is one way to determine the benefits from customer knowledge contribution. More specifically, firms should be cognizant of the customer's technology proficiency, as well as skills needed for creating technological innovation, as this will determine if the customer is capable of providing engineering support during the development process. Another factor to consider with respect to capability is the scope of internal integration. Inadequate communication among internal functions could limit the benefits obtained from collaboration with customers. Thus, using appropriate approaches that should be aligned with the level of product uncertainty could be a suitable strategy for both the firm and the customer, as it assists them in deriving the maximum benefit from knowledge integration.

\subsection{Limitations and further research}

One of the main challenges I had to overcome during my $\mathrm{PhD}$ studies was adjusting the scope of this thesis. Given that I have conducted some additional research activities that were not directly related to the aims of the present study, I had to decide which aspects to report in this thesis and which to share in independent academic publications. However, all the aforementioned initiatives helped me see the path for future research in this field more clearly, and have therefore been highly beneficial.

One possible path for future research in this field is to explore the role of customers in innovation supply chains. The changing role of customers into knowledge suppliers indicates that the product supply chain may not coincide with the innovation supply chain. Therefore, this is critical for understanding the process of knowledge integration with customers in the innovation supply chain, which has thus far been insufficiently explored in academic research. Therefore, based on the findings of this study, future research could focus on enhancing the understanding of the process of knowledge integration with customers by conceptualizing the innovation supply chain and determining its implications for the management of innovation.

In addition, considering the ongoing relationship between firms and some of their customers, further investigation of strategic alignment would also be highly beneficial. This could include 
in-depth investigation of the link between firm- and project-level strategies for integrating knowledge with customers. Such research initiatives could focus on the challenges encountered when linking these two levels, as well as discuss the short- and long-term goals of the firms, as these will affect the need for integration of customer knowledge.

Concerning the last idea, firms must establish whether maintaining collaborative relationships with one specific customer is more beneficial than attempting to integrate knowledge with a wider range of customers, as both approaches have advantages and disadvantages in terms of resource investment and potential outcomes. When considering approaching new customers for collaboration, the firm must ascertain that they have sufficient knowledge as well as willingness to take part in collaborative product development. However, due to different reasons, it may be difficult to accurately assess the most suitable knowledge that the firm would need, as well as whether a particular customer has that knowledge. Therefore, further studies could investigate assessment approaches and criteria for customer selection.

The dynamic process of knowledge integration under a contingency perspective is a potential area for further investigation. Previous studies in the context of interorganizational relationships explored the effects of some moderating and mediating factors that can affect the firm's openness to external knowledge (e.g., Laursen and Salter, 2006). Among different factors, the degree of innovation seems promising for further study. In addition to examining other contingency factors, it would be beneficial to investigate the process of knowledge integration not only in relation to product development but also in other contexts, such as solution innovation or service innovation.

Moreover, adopting the case study approach in this research endeavor limited the potential to explore the perspectives of customers on the dynamic process approach, commitment, and technical capability factors. Therefore, it would be highly fruitful to study these factors from the perspective of customers. 


\section{References}

Aarikka-Stenroos, L. and Jaakkola, E. (2012). Value co-creation in knowledge intensive business services: A dyadic perspective on the joint problem solving process. Industrial Marketing Management, 41(1), pp. 15-26.

Akao, Y. (1990). Quality function deployment: Integrating customer requirements into product design. Portland, OR: Productivity Press.

Akgün, A. E., Keskin, H., Byrne, J. C., and Aren, S. (2007). Emotional and learning capability and their impact on product innovativeness and firm performance. Technovation, 27(9), pp.501-513.

Alam, I. and Perry, C. (2002). A customer-oriented new service development process. Journal of services Marketing, 16(6), pp.515-534.

Athaide, G. A. and Klink, R. R. (2009). Managing seller-buyer relationships during new product development. Journal of Product Innovation Management, 26(5), pp.566-577.

Ayres, L., Kavanaugh, K. and Knafl, K.A. (2003). Within-case and across-case approaches to qualitative data analysis. Qualitative health research, 13(6), pp.871-883.

Beecham, M. A. and Cordey-Hayes, M. 1998. Partnering and knowledge transfer in the UK motor industry. Technovation, 18(3), pp.191-205.

Bengtsson, L., Lakemond, N. and Dabhilkar, M. (2013). Exploiting supplier innovativeness through knowledge integration. International Journal of Technology Management 12, 61(3/4), pp.237-253.

Berggren, C., Bergek, A., Bengtsson, L., Hobday, M. and Söderlund, J. (2011). Knowledge Integration and Innovation-Critical Challenges Facing International Technology-Based Firms. Oxford: Oxford University Press.

Billington, J. (1998). Customer-driven innovation. Harvard Management Update, 3(7), pp.1-3.

Blazevic, V. and Lievens, A. (2008). Managing innovation through customer coproduced knowledge in electronic services: An exploratory study, Journal of The Academy of Marketing Science, 36, pp.138-151.

Boland Jr, R. J. (1978). The process and product of system design. Management Science, 24(9), pp.887-898.

Bonner, J. M. (2010). Customer interactivity and new product performance: Moderating effects of product newness and product embeddedness. Industrial Marketing Management, 39(3), pp.485-492.

Bonoma, T. V. (1985). Case research in marketing: Opportunities, problems, and a process. Journal of Marketing Research, 22(2), pp.199-208.

Brewer, J. and Hunter, A. (2006). Foundations of multimethod research. London, UK: Sage Publications.

Brown, J.S. and Duguid, P. (2001). Knowledge and organization: A social-practice perspective. Organization science, 12(2), pp.198-213.

Brown, S.L. and Eisenhardt, K.M. (1995). Product development: Past research, present findings, and future directions. Academy of management review, 20(2), pp.343-378.

Brockhoff, K. (2003). Customers' perspectives of involvement in new product development. International Journal of Technology Management, 26(5-6), pp.464-481. 
Brusoni, S. (2005). The limits to specialization: problem solving and coordination in 'modular networks'. Organization Studies, 26(12), pp.1885-1907.

Bryman, A. (2008). Why do researchers integrate/combine/mesh/blend/mix/merge/fuse quantitative and qualitative research. Advances in mixed methods research, pp.87-100.

Bryman, A. and Bell, E. (2007). Business research methods (2nd ed.). Oxford: Oxford University Press.

Callahan, J. and Lasry, E. (2004). The importance of customer input in the development of very new products. $R \& D$ Management, 34(2), pp.107-120.

Chesbrough, H. W. (2006). Open innovation: The new imperative for creating and profiting from technology. Place of publication: Harvard Business Press.

Christensen, C. M. and Bower, J. L. (1996). Customer power, strategic investment, and the failure of leading firms. Strategic Management Journal, 17(3), pp.197-218.

Christensen, C. (1997). Patterns in the evolution of product competition. European Management Journal, 15(2), pp.117-127.

Cohen, W. M. and Levinthal, D. A. (1990). Absorptive capacity: A new perspective on learning and innovation. Administrative Science Quarterly, 35(1), pp.128-152.

Cooper, R. G. (2008). Perspective: The stage-gate ${ }^{\circledR}$ idea-to -launch process - update, what's new, and NexGen systems. Journal of Product Innovation Management, 25(3), pp.213-232.

Cooper, R. G. and Edgett, S. (2008). Ideation for product innovation: What are the best methods. PDMA Visions Magazine, 1(1), pp.12-17.

Cooper, R. G. and Edgett, S. J. (2012). Best practices in the idea-to-launch process and its governance. Research-Technology Management, 55(2), pp.43-54.

Coviello, N. E. and Joseph, R. M. (2012). Creating major innovations with customers: Insights from small and young technology firms. Journal of Marketing, 76(6), pp.87-104.

Creswell, J.W. (2013). Qualitative inquiry and research design: Choosing among five approaches. Sage.

Daft, R. L. and Lengel, R. H. (1986). Organizational information requirements: Media richness and structural design. Management Science, 32(5), pp.554-571.

Dahan, E. and Hauser, J. R. (2002). The virtual customer. Journal of Product Innovation Management, 19(5), pp.332-353.

De Boer, M., Van Den Bosch, F. A. and Volberda, H. W. (1999). Managing organizational knowledge integration in the emerging multimedia complex. Journal of Management Studies, 36(3), pp.379-398.

Dobler, D.W. and Burt, D.N. (1996). Purchasing and Supply Management. New York: McGraw-Hill.

Dowlatshahi, S. (1998). Implementing early supplier involvement: A conceptual framework. International Journal of Operations \& Production Management, 18(2), pp.143-167.

Droge, C., Jayaram, J. and Vickery, S. K. (2004). The effects of internal versus external integration practices on time-based performance and overall firm performance. Journal of Operations Management, 22(6), pp.557-573.

Dubois, A. and Gadde, L.E. (2002). Systematic combining: an abductive approach to case research. Journal of business research, 55(7), pp.553-560.

Dyer, J. H. and Nobeoka, K. (2000). Creating and managing a high-performance knowledgesharing network: The Toyota case. Strategic Management Journal, 21(3), pp.345-367. 
Dyer, J.H. and Singh, H, (1998). The relational view: Cooperative strategy and sources of interorganizational competitive advantage. Academy of management review, 23(4), pp.660679.

Edquist, C., Hommen, L. and McKelvey, M. D. (2001). Innovation and employment: Process versus product innovation. Edward Elgar Publishing.

Eisenhardt, K. M. (1989). Building Theories from Case Study Research. The Academy of Management Review, 14(4), pp.532-550.

Eisenhardt, K.M. and Tabrizi, B.N. (1995). Accelerating adaptive processes: Product innovation in the global computer industry. Administrative science quarterly, pp.84-110.

Emden, Z., Calantone, R.J. and Droge, C. (2006). Collaborating for new product development: selecting the partner with maximum potential to create value. Journal of product innovation management, 23(4), pp.330-341.

Engwall, M. and Westling, G. (2004). Peripety in an R\&D drama: Capturing a turnaround in project dynamics. Organization Studies, 25(9), pp.1557-1578.

Enkel, E., Kausch, C. and Gassmann, O. (2005). Managing the risk of customer integration. European Management Journal, 23(2), pp.203-213.

Eslami, M. H. and Lakemond, N. (2016). Internal integration in complex collaborative product development projects. International Journal of Innovation Management, $20(1), 1650008$.

Eslami, M. H. and Lakemond, N. (2016). Knowledge integration with customers in collaborative product development projects. Journal of Business \& Industrial Marketing, 31(7), pp.889-900.

Eslami, M. H., Lakemond., and Brusoni, S. (2016). Knowledge integration in complex systems development: what suppliers actually do to integrate knowledge with customers?. Under revision in a scientific journal.

Eslami, M. H., and Lakemond, N. (2016). Knowledge integration with customers in product development processes: Empirical evidence from Swedish manufacturing firms. Working paper to be submitted to a scientific journal.

Eslami, M. H., and Lakemond, N. (2016). The role of technical capability and locus of initiative on knowledge integration with customers in collaborative product development. Working paper to be submitted to a scientific journal.

Fang, E. (2008). Customer participation and the trade-off between new product innovativeness and speed to market. Journal of Marketing, 72(4), pp.90-104.

Fang, E., Palmatier, R. W. and Evans, K. R. (2008). Influence of customer participation on creating and sharing of new product value. Journal of the Academy of Marketing Science, 36(3), pp.322-336.

Faraj, S. and Sproull, L. (2000). Coordinating expertise in software development teams. Management Science, 46(12), pp.1554-1568.

Faraj, S. and Xiao, Y. (2006). Coordination in fast-response organizations. Management science, 52(8), pp.1155-1169.

Felin, T. and Zenger, T. R. (2014). Closed or open innovation? Problem solving and the governance choice. Research Policy, 43(5), pp.914-925.

Florida, R., Mellander, C. and King, K. (2015). The global creativity index 2015. Retrieved from Martin Prosperity Institute website: http://martinprosperity.org/media/GlobalCreativity-Index-2015.pdf (January, 2015). 
Flyvbjerg, B. (2006). Five misunderstandings about case-study research. Qualitative Inquiry, 12(2), pp.219-245.

Garbarino, E. and Johnson, M. S. (1999). The different roles of satisfaction, trust, and commitment in customer relationships. The Journal of Marketing, volume(issue), pp.70-87.

Gatignon, H. and Xuereb, J. M. (1997). Strategic orientation of the firm and new product performance. Journal of Marketing Research, pp.77-90.

Gerwin, D. and Barrowman, N.J. (2002). An evaluation of research on integrated product development. Management Science, 48(7), pp.938-953.

Geyskens, I., Steenkamp, J. B. E., Scheer, L. K. and Kumar, N. (1996). The effects of trust and interdependence on relationship commitment: A trans-Atlantic study. International Journal of Research in Marketing, 13(4), pp.303-317.

Golafshani, N. (2003). Understanding reliability and validity in qualitative research. The qualitative report, 8(4), pp.597-606.

Grandori, A. (2001). Neither hierarchy nor identity: Knowledge-governance mechanisms and the theory of the firm. Journal of management and Governance, 5(3-4), pp.381-399.

Grant, R.M. (1996a). Toward a knowledge-based theory of the firm. Strategic management journal, 17(S2), pp.109-122.

Grant, R. M. (1996b). Prospering in dynamically-competitive environments: Organizational capability as knowledge integration. Organization Science, 7(4), pp.375-387.

Grant, R.M. and Baden-Fuller, C. (2004). A knowledge accessing theory of strategic alliances, Journal of Management Studies, 41(1), pp.61-84.

Greer, C. R. and Lei, D. (2012). Collaborative innovation with customers: A review of the literature and suggestions for future research. International Journal of Management Reviews, 14(1), pp.63-84.

Griffin, A. (1997). PDMA research on new product development practices: Updating trends and benchmarking best practices. Journal of product innovation management, 14(6), pp.429-458.

Griffin, A. and Hauser, J. R. (1993). The voice of the customer. Marketing Science, 12(1), pp.127.

Grönlund, J., Sjödin, D. R. and Frishammar, J. (2010). Open innovation and the stage-gate process: A revised model for new product development. California Management Review, 52(3), pp.106-131.

Gruner, K. E. and Homburg, C. (2000). Does customer interaction enhance new product success? Journal of Business Research, 49(1), pp.1-14.

Gustafson, A., Herrmann, A. and Huber, F. (2000). Conjoint analysis as an instrument of market research practice. In: Conjoint measurement: Methods and applications. Berlin: Springer, pp.5-46.

Hamel, G. (1991). Competition for competence and interpartner learning within international strategic alliances. Strategic management journal, 12(S1), pp.83-103.

Hauser, J., Tellis, G.J. and Griffin, A. (2006). Research on innovation: A review and agenda for marketing science. Marketing science, 25(6), pp.687-717.

Helm, S. and Salminen, R. T. (2010). Basking in reflected glory: Using customer reference relationships to build reputation in industrial markets. Industrial Marketing Management, 39(5), pp.737-743. 
Herstatt, C. and Hippel, E. (1992). From experience: Developing new product concepts via the lead user method: A case study in a "low-tech" field. Journal of Product Innovation Management, 9(3), pp.213-221.

Hillebrand, B. and Biemans, W.G. (2004). Links between internal and external cooperation in product development: An exploratory study. Journal of Product Innovation Management, 21(2), pp.110-122.

Homburg, C. and Kuehnl, C. (2014). Is the more always better? A comparative study of internal and external integration practices in new product and new service development. Journal of Business Research, 67(7), pp.1360-1367.

Huang, Y.T. and Chu, W. (2010). Enhancement of product development capabilities of OEM suppliers: inter-and intra-organisational learning. Journal of Business \& Industrial Marketing, 25(2), pp.147-158.

Huang, J.C. and Newell, S. (2003). Knowledge integration processes and dynamics within the context of cross-functional projects. International Journal of Project Management, 21, pp.167-176.

Huovila, P. and Seren, K. J. (1998). Customer-oriented design methods for construction projects. Journal of Engineering Design, 9(3), pp.225-238.

Inkpen, A. C. and Dinur, A. (1998). Knowledge management processes and international joint ventures. Organization Science, 9(4), pp.454-468.

Jeppesen, L. B. and Molin, M. J. (2003). Consumers as co-developers: Learning and innovation outside the firm. Technology Analysis \& Strategic Management, 15(3), pp.363-383.

Johannessen, J. A. (2009). A systemic approach to innovation: The interactive innovation model. Kybernetes, 38(1/2), pp.158-176.

Kandemir, D., Calantone, R. and Garcia, R. (2006). An exploration of organizational factors in new product development success. Journal of Business \& Industrial Marketing, 21(5), pp.300-310.

Kaulio, M. A. (1998). Customer, consumer and user involvement in product development: A framework and a review of selected methods. Total Quality Management, 9(1), pp.141-149.

Kim, J. and Wilemon, D. (2002). Focusing the fuzzy front-end in new product development. $R \& D$ Management, 32(4), pp.269-279.

Kogut, B. and Zander, U. (1992). Knowledge of the firm, combinative capabilities, and the replication of technology. Organization Science, 3(3), pp.383-397.

Kohli, A. K. and Jaworski, B. J. (1990). Market orientation: The construct, research propositions, and managerial implications. The Journal of Marketing, pp.1-18.

Kotabe, M., Martin, X. and Domoto, H. (2003). Gaining from vertical partnerships: Knowledge transfer, relationship duration, and supplier performance improvement in the U.S. and Japanese automotive industries, Strategic Management Journal, 24(issue), pp.293-316.

Koufteros, X., Vonderembse, M. and Jayaram, J. (2005). Internal and external integration for product development: The contingency effects of uncertainty, equivocality, and platform strategy. Decision Sciences, 36(1), pp.97-133.

Krause, D. R. (1999). The antecedents of buying firms' efforts to improve suppliers. Journal of Operations Management, 17(2), pp.205-224. 
Krause, D. R., Handfield, R. B. and Tyler, B. B. (2007). The relationships between supplier development, commitment, social capital accumulation and performance improvement. Journal of Operations Management, 25(2), pp.528-545.

Laage-Hellman, J., Lind, F. and Perna, A. (2014). Customer involvement in product development: An industrial network perspective. Journal of Business-to-Business Marketing, 21(4), pp.257-276.

LaBahn, D. W. and Krapfel, R. (2000). Early supplier involvement in customer new product development: A contingency model of component supplier intentions. Journal of Business Research, 47(3), pp.173-190.

Lagrosen, S. (2005). Customer involvement in new product development: A relationship marketing perspective. European Journal of Innovation Management, 8(4), pp.424-436.

Lakemond, N., Bengtsson, L., Laursen, K. and Tell, F. (2016). Match and manage: The use of knowledge matching and project management to integrate knowledge in collaborative inbound open innovation. Industrial and Corporate Change, 25(2), pp.333-352.

Lau, A. K. (2011). Supplier and customer involvement on new product performance: Contextual factors and an empirical test from manufacturer perspective. Industrial Management \& Data Systems, 111(6), pp.910-942.

Laursen, K. and Salter, A. (2006). Open for innovation: The role of openness in explaining innovation performance among UK manufacturing firms. Strategic Management Journal, 27(2), pp.131-150.

Lazzarotti, V. and Manzini, R. (2009). Different modes of open innovation: A theoretical framework and an empirical study. International Journal of Innovation Management, 13(4), pp.615-636.

Lempres, E. C. (2003). A product is born. The McKinsey Quarterly, 3(1).

Leonard, D. (2002). The limitations of listening. Harvard Business Review, 80(1), p.93.

Lettl, C. (2007). User involvement competence for radical innovation. Journal of Engineering and Technology Management, 24(1), pp.53-75.

Lijphart, A. (1971). Comparative politics and the comparative method. American political science review, 65(3), pp.682-693.

Lilien, G. L., Morrison, P. D., Searls, K., Sonnack, M. and Hippel, E. V. (2002). Performance assessment of the lead user idea-generation process for new product development. Management Science, 48(8), pp.1042-1059.

Lin, M. J. J. and Huang, C. H. (2012). The impact of customer participation on NPD performance: The mediating role of inter-organisation relationship. Journal of Business \& Industrial Marketing, 28(1), pp.3-15.

Lin, M.C., Wang, C.C. and Chen, T.C. (2006). A strategy for managing customer-oriented product design. Concurrent Engineering, 14(3), pp.231-244.

Lin, R. J., Chen, R. H. and Chiu, K. K. S. (2010). Customer relationship management and innovation capability: An empirical study. Industrial Management \& Data Systems, 110(1), pp.111-133.

Lindkvist, L. (2005). Knowledge communities and knowledge collectivities: a typology of knowledge work in groups. Journal of Management studies, 42(6), pp.1189-1210. 
Littler, D., Leverick, F. and Bruce, M. (1995). Factors affecting the process of collaborative product development: A study of UK manufacturers of information and communications technology products. Journal of Product Innovation Management, 12(1), pp.16-32.

Lukas, B. A. and Ferrell, O. C. (2000). The effect of market orientation on product innovation. Journal of The Academy of Marketing Science, 28(2), pp.239-247.

Lüthje, C. and Herstatt, C. (2004). The lead user method: An outline of empirical findings and issues for future research. $R \& D$ Management, 34(5), pp.553-568.

Machlup, F. (1984). Knowledge, Its Creation, Distribution, and Economic Significance: The branches of learning. Princeton university press.

Maltz, E., Souder, W. E. and Kumar, A. (2001). Influencing R\&D/marketing integration and the use of market information by R\&D managers: Intended and unintended effects of managerial actions. Journal of Business Research, 52(1), pp.69-82.

Marsh, S. and Stock, G.N. (2006). Creating dynamic capability: The role of intertemporal integration, knowledge retention, and interpretation. Journal of Product Innovation Management, 23(5), pp.422-436.

Merriam, S.B. (1998). Qualitative research and case study applications in education. Revised and expanded from. Jossey-Bass Publishers, 350 Sansome St, San Francisco, CA 94104.

Meyer, M.H. and DeTore, A. (1999). Product development for services. The Academy of Management Executive, 13(3), pp.64-76.

Mikkola, J.H. (2003). Modularity, component outsourcing, and inter-firm learning. $r \& d$ Management, 33(4), pp.439-454.

Millson, M. R. and Wilemon, D. (2002). The impact of organizational integration and product development proficiency on market success. Industrial Marketing Management, 31(1), pp.123.

Mishra, A. and Shah, R. (2009). In union lies strength: Collaborative competence in new product development and its performance effects. Journal of Operations Management, 27(4), pp.324-338.

Montoya-Weiss, M. M., Massey, A. P. and Song, M. (2001). Getting it together: Temporal coordination and conflict management in global virtual teams. Academy of management Journal, 44(6), pp.1251-1262.

Moorman, C., Zaltman, G. and Deshpande, R. (1992). Relationships between providers and users of market research: The dynamics of trust within and between organizations. Journal of Marketing Research, 29(3), p.314.

Morrison, P.D., Roberts, J.H. and Midgley, D.F. (2004). The nature of lead users and measurement of leading edge status. Research policy, 33(2), pp.351-362.

Muthusamy, S.K., Hur, D. and Palanisamy, R. (2008). Leveraging knowledge in buyer supplier alliances: A theoretical integration. International Journal of Management and Decision Making, 9(issue), pp.600-616.

Nambisan, S. (2002). Designing virtual customer environments for new product development: Toward a theory. Academy of Management, 27(3), pp.392- 413.

Ngo, L. V. and O'Cass, A. (2009). Creating value offerings via operant resource-based capabilities. Industrial Marketing Management, 38(1), pp.45-59.

Nonaka, I. (1994). A dynamic theory of organizational knowledge creation. Organization Science, 5(1), pp.14-37. 
Nonaka, I. and Takeuchi, H. (1995). The knowledge-creating company: How Japanese companies create the dynamics of innovation. Oxford University Press.

Okhuysen, G. A. and Bechky, B. A. (2009). 10 coordination in organizations: An integrative perspective. The Academy of Management Annals, 3(1), pp.463-502.

Okhuysen, G. A. and Eisenhardt, K. M. (2002). Integrating knowledge in groups: How formal interventions enable flexibility. Organization Science, 13(4), pp.370-386.

Olson, E. L. and Bakke, G. (2001). Implementing the lead user method in a high technology firm: A longitudinal study of intentions versus actions. Journal of Product Innovation Management, 18(6), pp.388-395.

Paustian, C. (2001). Better products through virtual customers. MIT Sloan Management Review, 42(3), pp.1-2.

Peled, M. and Dvir, D. (2012). Towards a contingent approach of customer involvement in defence projects: An exploratory study. International Journal of Project Management, 30(3), pp.317-328.

Pisano, G. P. (1994). Knowledge, integration, and the locus of learning: An empirical analysis of process development. Strategic management journal, 15(S1), pp.85-100.

Polanyi, M. (1966). The Tacit dimension. Routledge \& Kegan Paul.

Ragatz, G. L., Handfield, R. B. and Petersen, K. J. (2002). Benefits associated with supplier integration into new product development under conditions of technology uncertainty. Journal of Business Research, 55(5), pp.389-400.

Rindfleisch, A. and Moorman, C. (2001). The acquisition and utilization of information in new product alliances: A strength-of-ties perspective. Journal of marketing, 65(2), pp.1-18.

Ritter, T. and Walter, A. (2003). Relationship-specific antecedents of customer involvement in new product development. International Journal of Technology Management, 26(5-6), pp.482-501.

Rosell, D. T. and Lakemond, N. (2012). Collaborative innovation with suppliers: A conceptual model for characterising supplier contributions to NPD. International Journal of Technology Intelligence and Planning, 8(2), pp.197-214.

Rundquist, J. and Halila, F. (2010). Outsourcing of NPD activities: A best practice approach. European Journal of Innovation Management, 13(1), pp.5-23.

Schmickl, C. and Kieser, A. (2008). How much do specialists have to learn from each other when they jointly develop radical product innovations? Research Policy, 37(3), pp.473-491.

Sethi, R. (2000). New product quality and product development teams. Journal of Marketing, 64(2), pp.1-14.

Seybold, P. B. (2001). Get inside the lives of your customers. Harvard Business Review, 79(5), pp.80-91.

Simonin, B.L. (1999). Ambiguity and the process of knowledge transfer in strategic alliances. Strategic Management Journal, 20(7), pp.595-623.

Skarmeas, D., Katsikeas, C. S. and Schlegelmilch, B. B. (2002). Drivers of commitment and its impact on performance in cross-cultural buyer-seller relationships: The importer's perspective. Journal of International Business Studies, 33(4), pp.757-783.

Song, M. and Xie, J. (2000). Does innovativeness moderate the relationship between crossfunctional integration and product performance? Journal of International Marketing, 8(4), pp.61-89. 
Song, X.M., Montoya-Weiss, M.M. and Schmidt, J.B. (1997). Antecedents and consequences of cross-functional cooperation: A comparison of R\&D, manufacturing, and marketing perspectives. Journal of Product Innovation Management, 14, pp.35-47.

Song, M. and Montoya-Weiss, M.M., 2001. The effect of perceived technological uncertainty on Japanese new product development. Academy of Management journal, 44(1), pp.61-80.

Spender, J. C. (1996). Making knowledge the basis of a dynamic theory of the firm. Strategic Management Journal, 17(S2), pp.45-62.

Squire, B., Cousins, P.D. and Brown, S. (2009). Cooperation and knowledge transfer within buyer-supplier relationships: The moderating properties of trust, relationship duration and supplier performance. British Journal of Management, 20(4), pp.461-477.

Subramanian, A.M. and Soh, P.H. (2006). Knowledge integration and effectiveness of open source software development projects. PACIS 2006 Proceedings, p.111.

Swink, M. (1999). Threats to new product manufacturability and the effects of development team integration processes. Journal of Operations Management, 17(6), pp.691-709.

Takeishi, A. (2001). Bridging inter-and intra-firm boundaries: Management of supplier involvement in automobile product development. Strategic management journal, 22(5), pp.403-433.

Tang, H.K., 1998. An integrative model of innovation in organizations. Technovation, 18(5), pp.297-309.

Teece, D. and Pisano, G. (1994). The dynamic capabilities of firms: An introduction. Industrial and corporate change, 3(3), pp.537-556.

Tell, F. (2011). A survey in the field, in Berggren, C., Bergek, A., Bengtsson, L., Hobday, M., and Söderlund, J. (Eds.), Knowledge Integration and Innovation. Oxford: Oxford University Press.

Thomke, S. and Fujimoto, T. (2000). The effect of "front-loading" problem-solving on product development performance. Journal of Product Innovation Management, 17(2), pp.128 142.

Tiwana, A. (2008). Do bridging ties complement strong ties? An empirical examination of alliance ambidexterity. Strategic Management Journal, 29(3), pp.251-272.

Tiwana, A. and McLean, E. (2005). Expertise integration and creativity in information systems development. Journal of Management Information Systems, 22(1), pp.13-43.

Tsai, W. (2001). Knowledge transfer in intraorganizational networks: Effects of network position and absorptive capacity on business unit innovation and performance. Academy of Management Journal, 44(5), pp.996-1004.

Ulwick, A. W. (2002). Turn customer input into innovation. Harvard Business Review, 80(1), pp. 91-97.

Un, C. A., Cuervo-Cazurra, A. and Asakawa, K. (2010). R\&D collaborations and product innovation. Journal of Product Innovation Management, 27(5), pp.673-689.

Veryzer, R. W. and Borja de Mozota, B. (2005). The impact of user-oriented design on new product development: An examination of fundamental relationships. Journal of Product Innovation Management, 22(2), pp.128-143.

von Hippel, E. (1976). The dominant role of users in the scientific instrument innovation process. Research Policy, 5(3), pp.212-239.

von Hippel, E. (1986). Lead users: A source of novel product concepts. Management Science, 32(7), pp.791-805 
von Hippel, E. (1988). The sources of innovation. New York: Oxford University Press.

von Hippel, E. and Katz, R. (2002). Shifting innovation to users via toolkits. Management Science, 48(7), pp.821-833.

Wagner, S. M. (2010). Supplier traits for better customer firm innovation performance. Industrial Marketing Management, 39(7), pp.1139-1149.

Wagner, S. M. and Hoegl, M. (2006). Involving suppliers in product development: Insights from R\&D directors and project managers. Industrial Marketing Management, 35(8), pp.936-943.

Walter, A. (2003). Relationship-specific factors influencing supplier involvement in customer new product development. Journal of Business Research, 56(9), pp.721-733.

Wheelwright, S.C. and Clark, K.B. (1992). Revolutionizing product development - Quantum leaps in speed, efficiency, and quality. New York: Free Press.

Wijnhoven, F. (1998). Knowledge logistics in business contexts: Analyzing and diagnosing knowledge sharing by logistics concepts. Knowledge and Process Management, 5(3), pp.143-157.

Wiklund, J. and Shepherd, D. (2005). Entrepreneurial orientation and small business performance: A configurational approach. Journal of Business Venturing, 20(1), pp.71-91.

Wolpert, J. D. (2002). Breaking out of the innovation box. Harvard Business Review, 80(8), pp.76-83.

Wu, L.W. and Lin, J.R. (2013). Knowledge sharing and knowledge effectiveness: Learning orientation and co-production in the contingency model of tacit knowledge. Journal of Business \& Industrial Marketing, 28(8), pp.672-686.

Wynstra, F., von Corswant, F. and Wetzels, M. (2010). In chains? An empirical study of antecedents of supplier product development activity in the Automotive Industry. Journal of Product Innovation Management, 27(5), pp.625-639.

$\mathrm{Xu}, \mathrm{M}$. and Walton, J. (2005). Gaining customer knowledge through analytical CRM. Industrial management \& data systems, 105(7), pp.955-971.

Yan, T. and Dooley, K. J. (2013). Communication intensity, goal congruence, and uncertainty in buyer-supplier new product development. Journal of Operations Management, 31(7), pp.523-542.

Yen, Y.X. and Hung, S.W. (2013). How does supplier's asset specificity affect product development performance? A relational exchange perspective. Journal of Business \& Industrial Marketing, 28(4), pp.276-287.

Yin, R.K. (2003). Case study research design and methods third edition. Applied social research methods series, 5

Yin, R.K. (2009). Case study research: Design and methods. Los Angeles: Sage.

Yli-Renko, H., Autio, E. and Sapienza, H. J. (2001). Social capital, knowledge acquisition, and knowledge exploitation in young technology-based firms. Strategic Management Journal, 22(6-7), pp.587-613.

Zirpoli, F. and Camuffo, A. (2009). Product architecture, inter-firm vertical coordination and knowledge partitioning in the auto industry. European Management Review, 6(4), pp.250264.

Zollo, M. and Winter, S. G. (2002). Deliberate learning and the evolution of dynamic capabilities. Organization Science, 13(3), pp.339-351. 
Öberg, C. (2010). Customer roles in innovations. International Journal of Innovation Management, 14(06), pp.989-1011. 


\section{Appendix A - Interview Guide}

General questions:

- What is your role and responsibility in firm and specifically about the Project?

- Can you describe about division/unit/Department that you are working?

- What are the main advantage and disadvantage of your organization's structural arrangement for integration within companies?

\section{Project}

- How was the project start?

- How was the project organized at your firm?

- Number of employees

- Responsibilities

- Did you experience ant technical difficulties throughout the development process?

- Would you describe the project based on the complexity/innovativeness?

- Describe about road map of the project at your company?

- What was the main focus of development at this project?

- Material technology

- Knowledge of designing of components or subsystems

- Your development project is based on

- Customer's request

- Market situations

- Competitors development

- Internal idea

- What kind of feasibility study did you have for the project?

- What external firms did you collaborate for this project (Except the customers)

- Are you satisfied with project results/outcomes?

\section{Customer}

- How the collaboration with customer start?

- How many customers did you have for this project initially?

- Please describe generally about the customer/customers of this project

- Long term relation

- Their volume of production

- Knowledge competency

- Innovativeness

- Their sales

- How did you work together?

- What functions are more involved in order to integrate with customers?

- Sales

-

- Describe about your roles and responsibilities in order to collaborate with customers

- What were the main difficulties while collaborating with customers? 
- What knowledge competency do you have in order to cooperate with your customers?

- Based on White box

- Grey Box

- Black Box

- How customers can identify your knowledge?

Knowledge integration with customers

A) Ideation/Concept phase

a. Did you receive any customer's product design in this stage? (How)

b. What type of specification and requirement did you receive from the customer?

i. value calculation

ii. Previous failures

iii. Effect of operational environment?

iv. previous solution/experience, challenges?

v. performance? Who described the performance, your firms or customers?

c. If each of these topics did not performed during study phase, when did you have them? which phase?

d. Any internal discussion between functions during this stage about the above topics

e. What have you learnt from customer during this phase?

B) During design

a. How your design effected from the interface with other systems in customer machine

b. Did you have enough knowledge about designing the system?

c. Did you discuss about (and how)

i. your design with customers?

ii. Did they have any competency in this area?

iii. Functionalities

d. Any other integration or discussion with customer during design phase

e. Is there any testing during design?

f. What mechanisms tools and techniques did you use in order to integrate with customer during design phase?

g. What have you learnt from customer during this phase?

C) During Testing

a. Testing was performed in your firm or customer industry?

b. How the installation performed?

c. What type of testing did you have?

d. What discussion did you have with customers regarding testing? (How)

e. What have you learnt from customer during this phase? (How)

f. What are the challenges regarding testing? (How)

g. Any internal knowledge integration between function during this stage 


\section{Appendix B - Survey questions and items}

Approximately how many employees does our company have (answer in integer equivalence)?

- $0-250$

- 251-500

- 500-1000

- $\quad$ More than 1000

Approximately how large was the turnover of your company the last fiscal year? (in thousands of kroners)

Which of the following best describes your job title?

How long have you been work in the current company?

Does your company have a formal organisation for research and development R\&D? (yes/no) (if yes) - How many employees work in the R\&D department?

\section{$\underline{\text { Knowledge integration }}$}

Please indicate the extent to which you agree with the following on 1 (not at all)customer interaction in new product development

- Errors and failures are discussed and analyzed with key customers, on all levels

- Our employees have the chance to talk with the customers' employees about new ideas, programs and activities that might be of use to the firm

- Our employees and customer's employees develop new product development concepts together

\section{Degree of customer involvement}

To what extent are your key customers involved in the following stages of new product development of your company

1 (not at all)5 (to a great extent)

- Idea generation

- Concept development

- Development

- Testing

- Commercialization 


\section{Innovation performance}

Please indicate how collaboration with your key customers in new product development has contributed to the following objectives over the last 3 years

1 (not at all)5 (to a great extent)

\section{Innovation efficiency}

- Reduced innovation risks

- Reduced new product/process development cost

- Reduced time to market

Innovation novelty

- Introduced new or significantly improved products or services

- Introduced new or significantly improved process of producing our products or services

- Opening of new markets

\section{Locus of initiative at customer}

Please indicate the degree to which your key customers contribute to the following:

1 (not at all)5 (to a great extent)

- Key customers present ideas/ suggestions for new product features

- Key customer present ideas about new materials, which can be used to produce the product.

\section{Locus of initiative at firms}

Please indicate the degree to which your key customers contribute to the following:

- We solicit key customers' opinions on product prototypes when developing new products.

- We involve key customers in the product design and development stage

- Involving customers have a major influence on the design of new products

\section{Firm's technical capability}

Please indicate your agreement with each of the following statements with respect to your firm's technical capability

- Compared to our competitors, our engineers are proficient with the latest technology

- Compared to our competitors, our engineers are skilled at creating
1 (not at all)5 (to a great extent)

1 (not at all)5 (to a great extent) 
technological innovations.

- Compared to our competitors, we do incorporate the external technology in our new products.

- Compared to our competitors, we do offer a high degree of engineering support to our customers.

- Compared to our competitors, we are able to respond quickly to technological changes.

\section{Customer technical capability}

Please indicate your agreement with each of the following statements with respect to your key customer's technical capability

1 (not at all)5 (to a great

- Compare to their competitors, our key customers are proficient with extent) the latest technology

- Compare to their competitors, our key customers are skilled at creating technological innovations

- Compare to their competitors, our key customers do contribute with the latest technology in our new products

- Compare to their competitors, our key customers do offer a high degree of engineering support to our customers

- Compare to their competitors, our ley customers are able to respond quickly to technological changes

\section{Absorptive Capacity}

Please indicate your agreement with each of the following statements with respect to possibility to capture external knowledge

1 (not at all)5 (to a great extent)

- We are able to identify external knowledge from our key customers.

- We have adequate internal routines to analyze the knowledge obtained from our key customers.

- We can successfully integrate existing knowledge with new knowledge acquired from our key customers.

- We are able to understand, analyze and interpret information from customer's knowledge.

- Compare to their competitors, our ley customers are able to respond quickly to technological changes

\section{Product uncertainty}

Please indicate the extent to which you agree with the following on 1 (not at customer interaction in new product development all)-5 (to a great extent)

- We produce complex products rather than simple products

- Our new products have a high degree of innovation

- Product development has a high degree of engineering content

- Our products are based on technologies that changing fast 


\section{$\underline{\text { Technological uncertainty }}$}

Please indicate your agreement with each of the following statements with 1 (not at all)respect to technological uncertainty in your industry?

- There is a high level of technological innovation in our industry.

- More complex products are provided in our industry.

- The technology in our industry is changing rapidly.

- Technological changes provide big opportunities in our industry.

\section{Firm's Strategy}

To what extent do you agree with the following statements regarding 1 (not at your company's strategy:

- We prioritize new product and service development and innovation to meet new and changing customer demands

- We strive to be the technological leader

- We focus on radical rather than gradual innovation

- We try to hire the best scientists and experts in the market

- R\&D and marketing are our core competencies

- We normally use innovative, flexible and non-routine techniques

- We have a broad product portfolio

- We have a broad technology base

\section{Intellectual property}

To what extent does your company intellectual property in collaboration with customers through the following alternatives?

- Patent

- Construction/Design

- Trademarks

- Business Secrets

- Confidentially agreements and other forms of contracts (eg., cooperation agreements)

- Copyright

- Product complexity

- Lead times
1 (not at all)-5 (to a great extent) 



\section{Part II}

The Papers 


\section{Papers}

The articles associated with this thesis have been removed for copyright reasons. For more details about these see:

http://urn.kb.se/resolve?urn=urn:nbn:se:liu:diva-133964 